\title{
PANDUAN DOKTER GIGI DALAM ERA NEW NORMAL
}
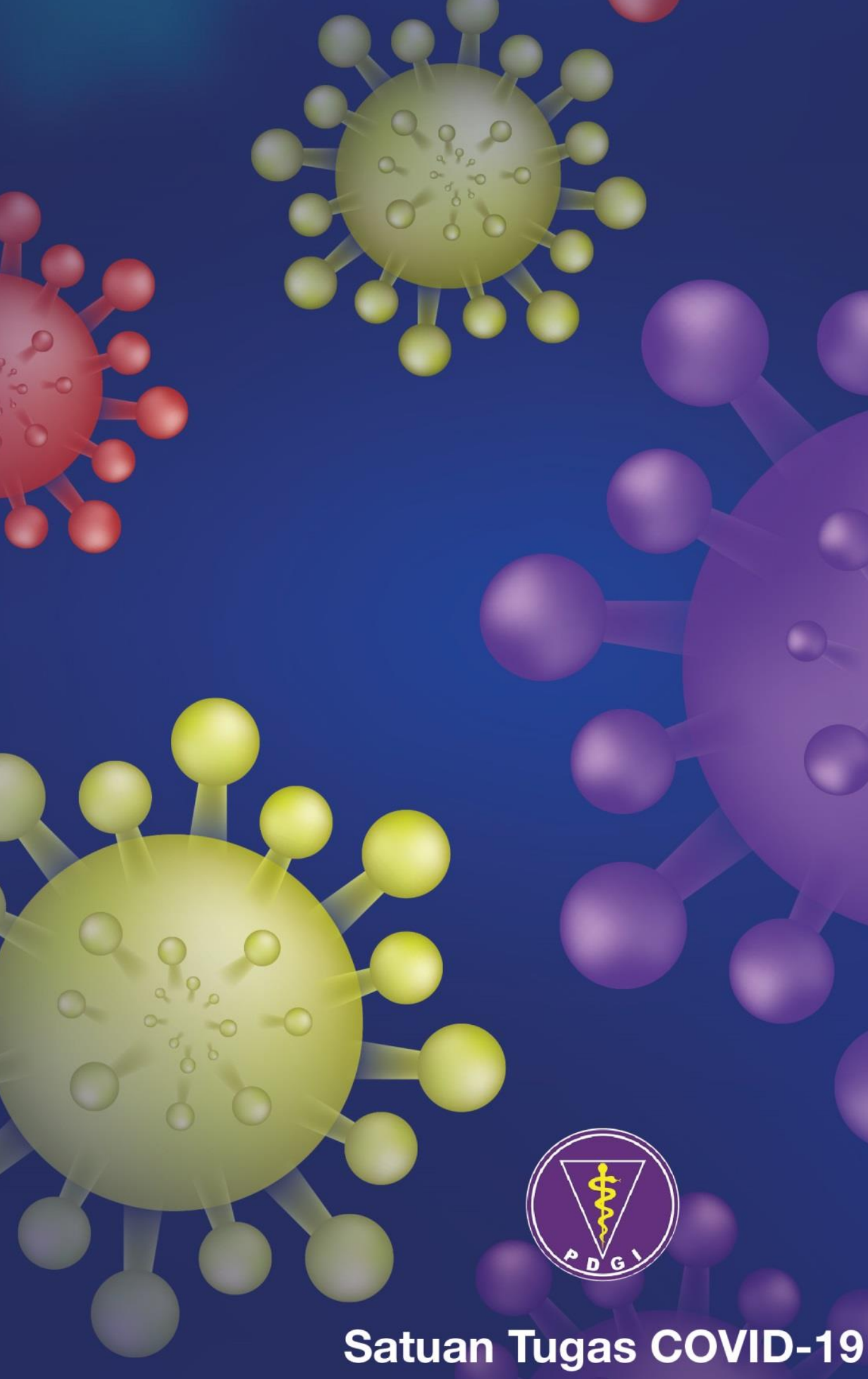

Pengurus Besar Persatuan Dokter Gigi Indonesia 2020 



\section{PANDUAN DOKTER GIGI DALAM ERA NEW NORMAL}

Satuan Tugas COVID-19

Pengurus Besar Persatuan Dokter Gigi Indonesia 2020 


\section{KATALOG DALAM TERBITAN}

\section{PANDUAN DOKTER GIGI DALAM ERA NEW NORMAL}

\section{Penyusun:}

1. Prof. Rahmi Amtha, drg., MDS., Sp.PM, Ph.D.

2. Indrayadi Gunardi, drg., Sp.PM

3. Iwan Dewanto, drg., MMR., Ph.D.

4. Dr. Armelia Sari Widyarman, drg., M.Kes. PBO

5. Citra Fragrantia Theodorea, drg., M.Si., Ph.D.

\section{Kontributor:}

1. Dr. R.M. Sri Hananto Seno, drg., Sp.BM(K)., M.M.

2. Warisan Pandapotan Kennedy Manurung, drg.

3. Sandra Mega, drg., MDSc, Sp. Ort.

\section{Editor:}

1. Indrayadi Gunardi, drg., Sp.PM

2. Dr. Armelia Sari Widyarman, drg., M.Kes. PBO

3. Prof. Rahmi Amtha, drg., MDS., Sp.PM, Ph.D.

4. Iwan Dewanto, drg., MMR., Ph.D.

$\begin{array}{ll}\text { Bahasa } & : \text { Indonesia } \\ \text { ISBN } & : 978-602-70470-4-4 \\ \text { Jumlah Halaman } & : 108 \text { halaman } \\ \text { Ukuran Buku } & : 19 \mathrm{~cm} \times 26 \mathrm{~cm}\end{array}$

Cetakan Pertama, Juli 2020

Penerbit : Pengurus Besar Persatuan Dokter Gigi Indonesia

\section{UNDANG UNDANG REPUBLIK INDONESIA \\ NOMOR 19 TAHUN 2002 \\ TENTANG HAK CIPTA}

Pasal 2 Ayat (1)

Hak Cipta merupakan hak eksklusif bagi Pencipta atau Pemegang Hak Cipta untuk mengumumkan atau memperbanyak Ciptaannya, yang timbul secara otomatis setelah suatu ciptaan dilahirkan tanpa mengurangi pembatasan menurut peraturan perundangundangan yang berlaku.

\section{Pasal 72 Ayat (1)}

Barangsiapa dengan sengaja dan tanpa hak melakukan perbuatan sebagaimana dimaksud dalam Pasal 2 ayat (1) atau Pasal 49 ayat (1) dan ayat (2) dipidana dengan pidana penjara masing-masing paling singkat 1 (satu) bulan dan/atau denda paling sedikit Rp 1.000.000,00 (satu juta rupiah), atau pidana penjara paling lama 7 (tujuh) tahun dan/atau denda paling banyak Rp 5.000.000.000,00 (lima miliar rupiah).

\section{Ayat (2)}

Barangsiapa dengan sengaja menyiarkan, memamerkan, mengedarkan, atau menjual kepada umum suatu Ciptaan atau barang hasil pelanggaran Hak Cipta atau Hak Terkait sebagaimana dimaksud pada ayat (1) dipidana dengan pidana penjara paling lama 5 (lima) tahun dan/atau denda paling banyak Rp 500.000.000,00 (lima ratus juta rupiah). 


\section{PANDUAN DOKTER GIGI DALAM ERA NEW NORMAL}

\section{SATUAN TUGAS COVID-19}

\section{Pengurus Besar Persatuan Dokter Gigi Indonesia}

\section{Penyusun:}

1. Prof. Rahmi Amtha, drg., MDS., Sp.PM, Ph.D.

Fakultas Kedokteran Gigi, Universitas Trisakti, Jakarta

2. Indrayadi Gunardi, drg., Sp.PM

Fakultas Kedokteran Gigi, Universitas Trisakti, Jakarta

3. Iwan Dewanto, drg., MMR., Ph.D.

Program Studi Kedokteran Gigi, Fakultas Kedokteran Gigi, Universitas Muhammadiyah Yogyakarta

4. Dr. Armelia Sari Widyarman, drg., M.Kes. PBO Fakultas Kedokteran Gigi, Universitas Trisakti, Jakarta

5. Citra Fragrantia Theodorea, drg., M.Si., Ph.D.

Fakultas Kedokteran Gigi, Universitas Indonesia, Jakarta

\section{Kontributor:}

1. Dr. R.M. Sri Hananto Seno, drg., Sp.BM(K)., M.M.

Ketua Pengurus Besar PDGI dan Tim Dokter Kepresidenan RI

2. Warisan Pandapotan Kennedy Manurung, drg.

Suku Dinas Kesehatan Jakarta Utara

3. Sandra Mega, drg., MDSc., Sp.Ort

Rumah Sakit Gigi dan Mulut LADOKGI RE Martadinata, Jakarta 


\section{KATA PENGANTAR \\ PENGURUS BESAR PERSATUAN DOKTER GIGI INDONESIA}

Dimulai akhir Desember 2019 terjadi wabah virus baru di dataran china terkhusus di daerah Wuhan, yang secara cepat menyebar diluar China bahkan dalam waktu 2 bulan hampir seluruh dunia terinfeksi COVID-19, sehingga WHO menyatakan Outbreak COVID-19 Global Pandemic. Pada tanggal 2 maret 2020 Indonesia mengumumkan dimulainya kejadian wabah di wilayah Jakarta, Jawa Barat, dan Bali, dalam waktu singkat kurang 1 bulan, 34 provinsi terdeteksi COVID-19. Oleh karena Presiden RI menyatakan bencana nasional non alam, maka dibentuklah Gugus Tugas Percepatan Penanganan COVID-19 yang diawali oleh BNBP dari tingkat pusat hingga wilayah provinsi.

Dengan adanya beberapa korban dokter gigi yang meninggal dunia akibat COVID-19, maka Kepala BNPB dan Kementerian Kesehatan menghimbau agar dokter gigi yang berisiko tinggi tertular COVID-19 saat memberikan pelayanan kesehatan gigi dan mulut, untuk sementara menghentikan pemberian pelayanan kecuali untuk kasus-kasus emergensi. Hampir 4 bulan para dokter gigi tidak praktik, tidak memberikan pelayanan langsung ke pasien, dan tidak dapat mengamalkan ilmu dan kompetensi dalam bentuk pengabdian kepada masyarakat. Banyak permintaan dan keluhan dari masyarakat, klinik, rumah sakit dan institusi pelayanan kesehatan agar para dokter gigi segera dapat berpraktik kembali, karena masyarakat kesulitan mendapatkan perawatan.

Seiring dengan wacana Pemerintah menerapkan Kehidupan Normal Baru, atau Adaptasi Kebiasaan Baru yang dikenal dengan sebutan era New Normal, PB-PDGl memberikan kesempatan kepada dokter gigi seluruh Indonesia untuk memulai praktik kembali dengan berbagai ketentuan yang harus ditaati. Ketentuan-ketentuan ini dimaksudkan untuk melindungi dokter gigi dan tenaga kesehatan pendukung agar tidak tertular COVID-19, serta menghindari adanya infeksi silang di ruang tempat praktik. Dengan diterbitkan dan diberlakukannya Buku Panduan Dokter Gigi Dalam Era New Normal, maka dimulailah para dokter gigi Indonesia untuk berpraktik kembali.

Buku ini memuat panduan secara lengkap, selain ketentuan berpraktik kembali di era new normal, tetapi juga tentang manajemen pembiayaan dan upaya promotif Kesehatan Gigi dan Mulut, yang didukung oleh literatur ilmiah yang kuat, sehingga dapat menjadi referensi bagi siapapun untuk penulisan ilmiah maupun penelitian. 
Ketua umum PB-PDGI memberikan apresiasi yang setinggi-tingginya kepada tim penulis buku Panduan Dokter Gigi Di Era New Normal, dengan dedikasi yang tinggi pula dan jerih payahnya mencari literatur, siang dan malam menyusun kata demi kata yang dirangkai menjadi kalimat-kalimat hingga terwujudnya buku ini yang menjadi pedoman bagi dokter gigi se-Indonesia untuk berpraktik di era new normal.

Dengan penuh harapan, agar dokter gigi Indonesia dapat menggunakan buku ini secara bijak dan tidak menjadi keterpaksaan. Semoga Allah SWT selalu melindungi kita semua dan memberikan yang terbaik.. Aamiin...Aamiin... Ya Robbal 'alamin. Demikian terima kasih.

Jakarta, 30 Juni 2020

Dr. RM Sri Hananto Seno, drg., SpBM(K),MM Ketua Umum PB-PDGI 


\section{KATA PENGANTAR}

Assalamualaikum wrwb

Dengan mengucapkan syukur Alhamdulilah atas berkah dan rahmat Allah SWT buku panduan Praktik Dokter Gigi di era New Normal dapat diselesaikan oleh tim Satgas COVID-19 Persatuan Besar Dokter Gigi Indonesia. Buku ini disusun sebagai lanjutan Surat Edaran PB PDGI no 2776/PBPDGI/III-3/2020 yang disebarkan sebagai panduan awal bagi dokter gigi terkait wabah Pandemi COVID-19.

COVID-19 merupakan penyakit yang menyerang saluran pernafasan akut yang mewabah di seluruh dunia. Per tanggal 29 Juni 2020, di dunia tercatat 9.962.193 orang terinfeksi dan 55.092 di Indonesia. Salah satu yang patut dijadikan waspada bagi semua manusia adalah karena transmisinya yang amat mudah dan cepat, sehingga perhatian akan penularan penyakit ini menjadi faktor utama yang harus selalu diperhatikan. Diketahui bahwa aktivitas dokter gigi sangat erat berhubungan dengan produksi aerosol terbesar dan hasil berbagai penelitian menunjukkan bahwa jumlah virus SARS-CoV-2 sangat banyak ditemukan di naso-orofaring dan saliva. Produksi aerosol dan droplet inilah yang menjadi ujung tombak perluasan penyebaran COVID-19 pada praktik dokter gigi. Oleh karenanya protokol kesehatan menjaga hygiene tangan, hygiene pernafasan, pembatasan jarak fisik, peningkatan daya tahan tubuh serta pengetahuan tentang pola penularan COVID-19 menjadi sangat penting untuk dipahami dan menjadi kewajiban bagi dokter gigi di Indonesia yang akan berpraktik kembali. Hal ini bertujuan agar angka morbiditas penyakit gigi dan mulut masyarakat Indonesia tidak semakin meningkat, yang akan justru menjadi salah satu faktor yang melemahkan sistem pertahanan tubuh. Merujuk pada berbagai sumber, tata kelola ruang praktik, alur dan tata cara pengerjaan pasien serta APD, perlu diatur sedemikan rupa sehingga dapat menurunkan risiko dokter gigi, perawat gigi, pasien, keluarga dan lingkungan sekitarnya terhadap transmisi COVID-19. Secara garis besar, keberhasilan dokter gigi dalam memutus rantai penularan COVID-19 tergantung pada 3 faktor utama yaitu 1) pengetahuan dan kemauan mengikuti protokol kesehatan yang telah ditetapkan; 2) barrier (batasan-batasan seperti menjaga jarak, penggunaan APD, dan sebagainya) dan 3) personal hygiene (seperti disebutkan diatas).

Pedoman umum ini ditujukan bagi dokter gigi di seluruh Indonesia sebagai rujukan

dalam menjalani praktik di era new normal menghadapi COVID-19. Pedoman umum 
ini disusun dengan mengadopsi bebagai Panduan Menghadapi Penyakit Virus SARS-CoV-2 dari berbagai sumber seperti WHO, CDC serta disarikan dari berbagai sumber referensi lainnya dari dalam dan luar negri yang sesuai dengan kondisi di Indonesia.

Buku Panduan edisi pertama ini mungkin belum memuat semua hal yang diperlukan oleh dokter gigi secara terperinci berdasarkan kondisi di daerah masing-masing, namun dapat menjadi panduan prinsip dasar pengelolaan praktik di era new normal COVID-19. Saya ucapkan banyak terima kasih kepada Ketua Umum PB-PDGI Dr. HM. Sri Hananto Seno, drg., Sp.BM(K), MM atas dukungannya dan tim penulis (Iwan Dewanto, drg., MMR, Ph.D., Indrayadi Gunardi, drg., Sp.PM, Dr. Armelia Sari, drg., M.Kes., PBO dan Citra Fragrantia Theodorea, drg., M.Si, Ph.D.) dan kontributor (Warisan Pandapotan Kennedy Manurung, drg.) yang telah bekerja keras bersama-sama menyusun dan mewujudkan buku ini serta teman sejawat lain yang telah memberikan masukan sehingga dapat diselesaikan dan segera dapat dimanfaatkan oleh teman sejawat se-Indonesia. Selamat menjalani praktik dalam suasana new normal, semoga selalu dalam lindunganNya.

Jakarta, 30 Juni 2020

Prof. Rahmi Amtha, drg., MDS., Sp.PM, Ph.D. Ketua Satgas COVID-19 PB-PDGI 


\section{DAFTAR ISI}

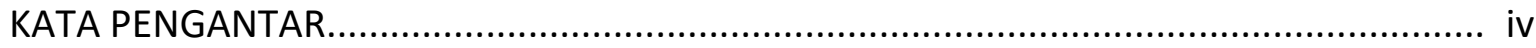

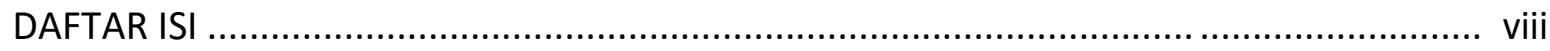

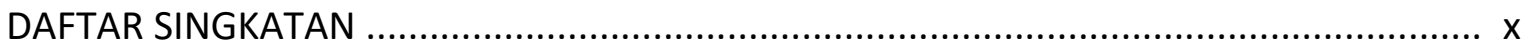

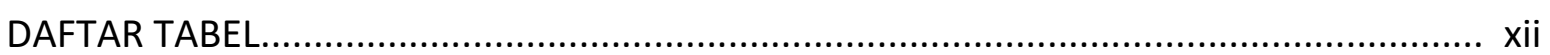

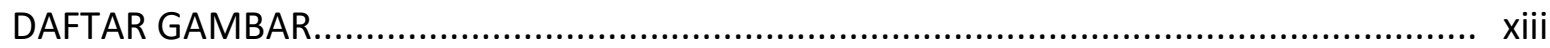

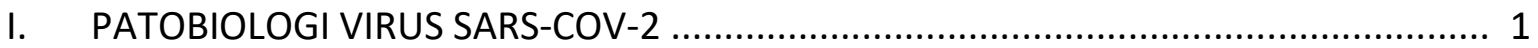

A. Karakteristik Virus SARS-CoV-2 ............................................................... 3

B. Penularan/Transmisi Virus.................................................................... 4

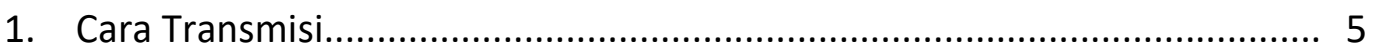

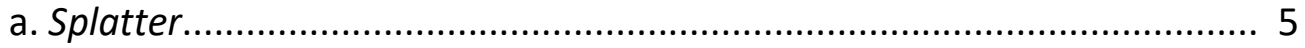

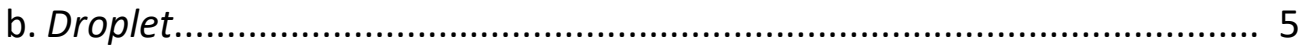

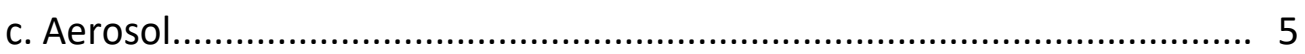

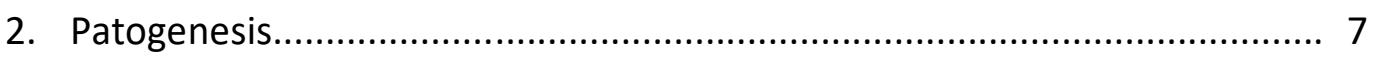

a. Metode pemeriksaan COVID-19...................................................... 7

b. Fase infeksi SARS-CoV-2 .............................................................. 10

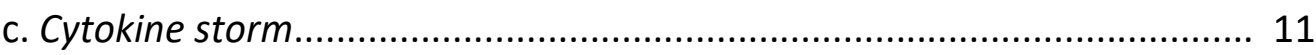

3. Virus SARS-CoV-2 Dalam Saliva......................................................... 12

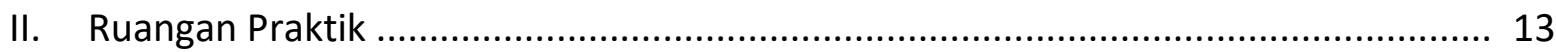

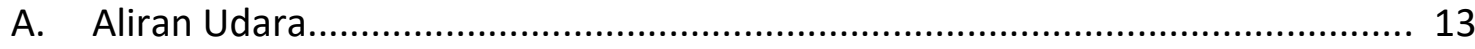

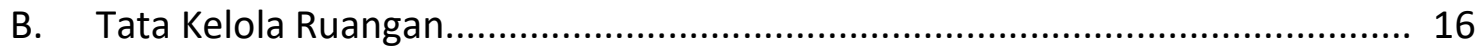

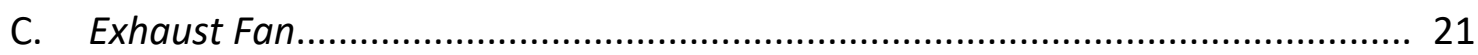

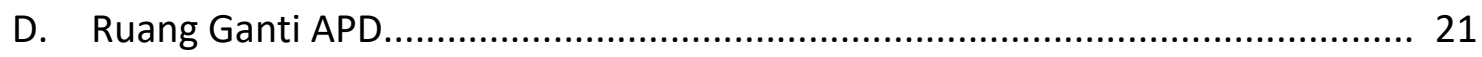

1. Ruang pemakaian (donning) APD......................................................... 22

2. Ruang melepas (doffing) APD............................................................... 23

E. Fasilitas Pendukung dan Ketentuan Lain.................................................. 26

F. Alat Kedokteran Gigi Tambahan .............................................................. 29

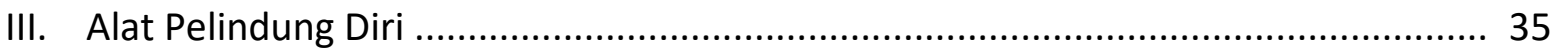

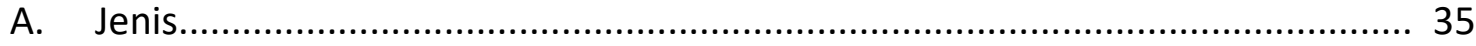

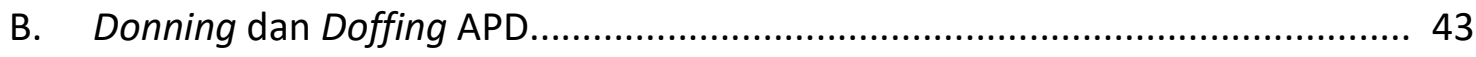

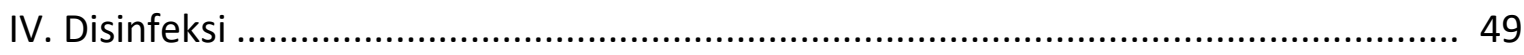

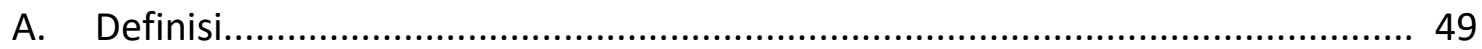

B. Kategori Barang (item) Yang Terkontaminasi............................................ 50

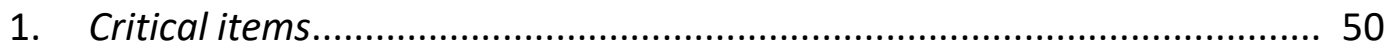




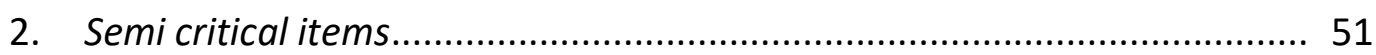

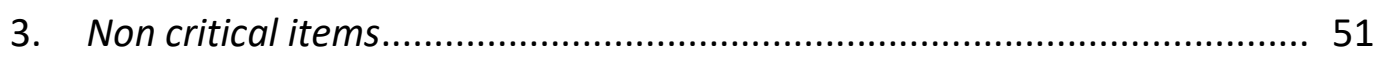

C. Jenis dan Metode Sterilisasi dan Disinfeksi................................................... 51

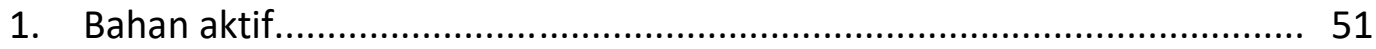

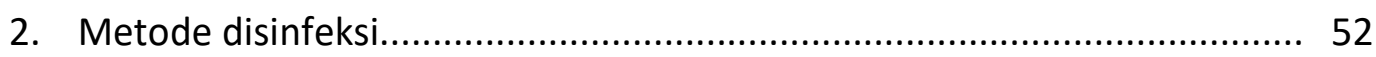

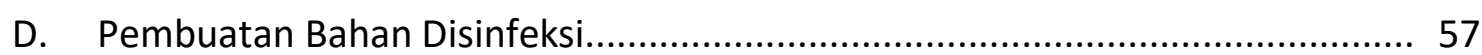

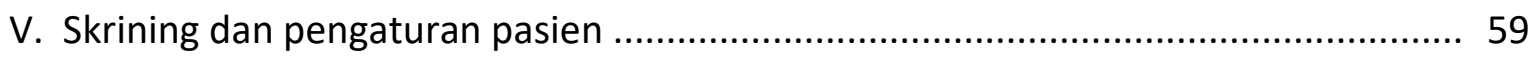

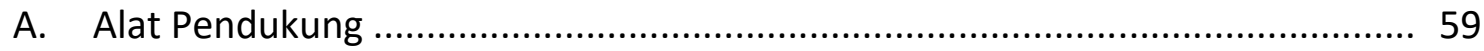

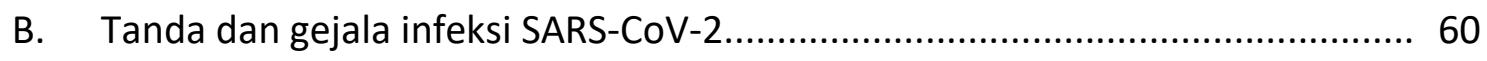

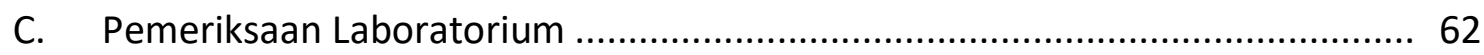

D. Pemeriksaan Rapid Test........................................................................ 63

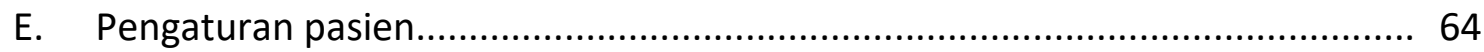

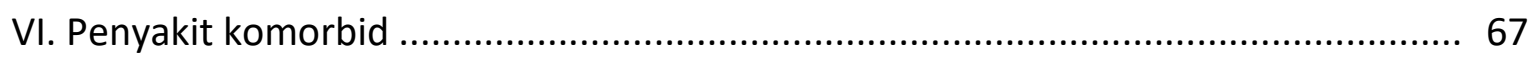

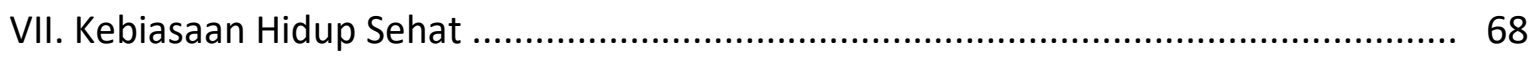

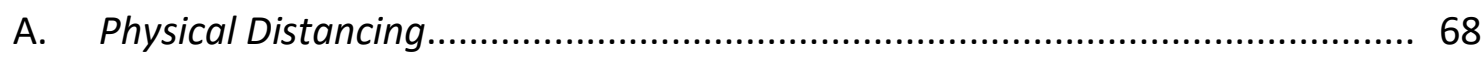

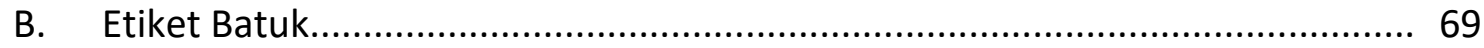

C. Kebersihan Diri dan Rumah..................................................................... 72

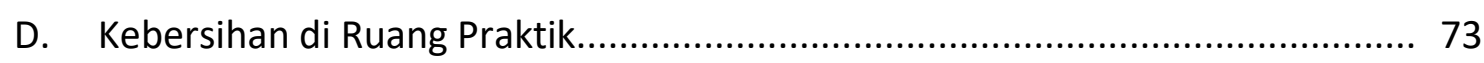

E. Kebersihan Diri Petugas Kesehatan........................................................... 74

F. Prosedur Pembersihan Petugas Kebersihan................................................ 75

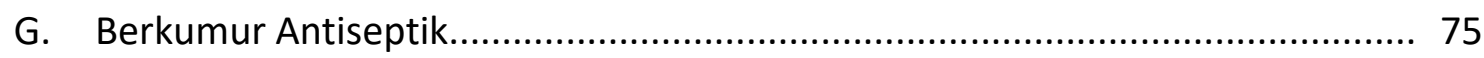

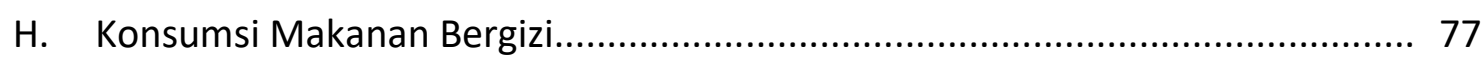

I. Perilaku Hidup Bersih dan Sehat............................................................... 78

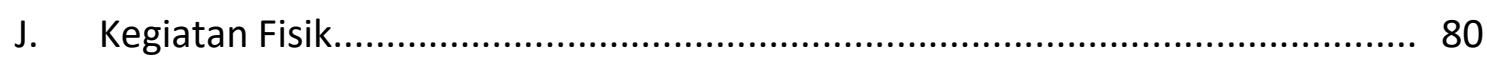

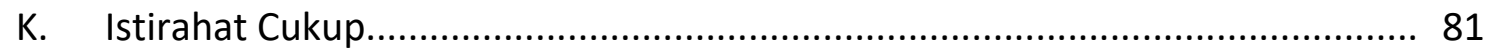

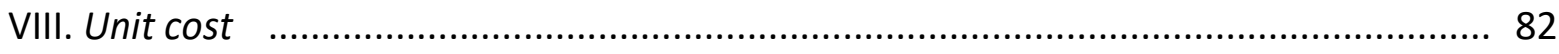

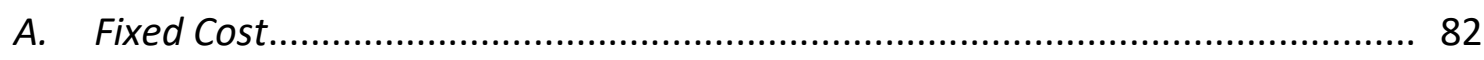

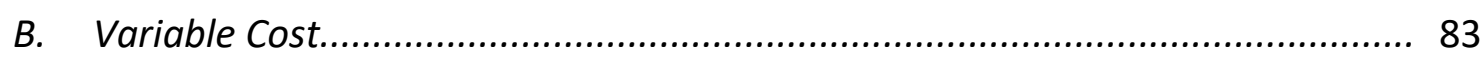

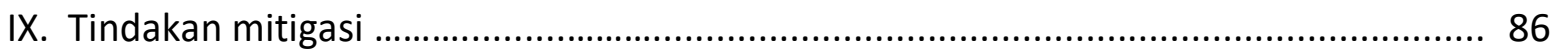

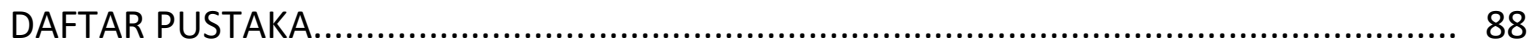




\section{DAFTAR SINGKATAN}

\begin{tabular}{|c|c|}
\hline$\alpha-\operatorname{CoV}$ & Alphacoronavirus \\
\hline$\beta-\mathrm{CoV}$ & Betacoronavirus \\
\hline $\mathrm{\gamma}-\mathrm{CoV}$ & Gammacoronavirus \\
\hline$\delta-\mathrm{CoV}$ & Deltacoronavirus \\
\hline ACE2 & Angiotensin Converting Enzyme 2 \\
\hline $\mathrm{ACH}$ & Air changes hour \\
\hline$A C$ & Air conditioner \\
\hline APD & Alat pelindung diri \\
\hline ARDS & Acute Respiratory Distres Syndrome \\
\hline ASI & Air susu ibu \\
\hline B cell & Lymphocyte B cell \\
\hline $\mathrm{CDC}$ & Centers for Disease Control and Prevention \\
\hline $\mathrm{CHX}$ & Chlorhexidine (gluconate atau digluconate) \\
\hline COVID-19 & Coronavirus disease 2019 \\
\hline DHCP & Dental Healthcare Personnel \\
\hline EtO & Etilen dioksida \\
\hline FDA & Food and Drug Administration \\
\hline FGF & Fibroblast growth factor \\
\hline G-CSF & Granulocyte colony-stimulating factor \\
\hline GERMAS & Gerakan masyarakat hidup sehat \\
\hline GM-CSF & Granulocyte-macrophage colony-stimulating factor \\
\hline GGO & Ground glass opacity \\
\hline $\mathrm{H}_{2} \mathrm{O}_{2}$ & Hidrogen peroksida \\
\hline HBV & Hepatitis $B$ virus \\
\hline HEPA & High-efficiency particulate air \\
\hline HIV & Human Immunodeficiency virus \\
\hline HVAC & Heating, ventilation, and air conditioning \\
\hline HVE & High volume evacuator \\
\hline ICTV & International Committee on Taxonomy of Viruses \\
\hline IFN & Interferon \\
\hline $\lg$ & Immunoglobulin \\
\hline IL & Interleukin \\
\hline IP10 & Interferon gamma-induced protein 10 \\
\hline ISPA & Infeksi saluran pernapasan atas \\
\hline
\end{tabular}




$\begin{array}{ll}\text { MCP1 } & \text { Monocyte Chemoattractant Protein-1 } \\ \text { MIP } & \text { Macrophage inflammatory protein } \\ \text { NK cell } & \text { Natural killer cell } \\ \text { OTG } & \text { Orang tanpa gejala } \\ \text { ODP } & \text { Orang dalam pemantauan } \\ \text { PCR } & \text { Polymerase chain reaction } \\ \text { PDGFB } & \text { Platelet Derived Growth Factor Subunit B } \\ \text { PDP } & \text { Pasien dalam pengawasan } \\ \text { PHBS } & \text { Perilaku Hidup Bersih dan Sehat } \\ \text { PMN } & \text { Polymorphonuclear } \\ \text { PPE } & \text { Personal protective equipment } \\ \text { PVP-I } & \text { Povidone iodine } \\ \text { RNA } & \text { Ribonucleic acid } \\ \text { RT-PCR } & \text { Reverse transcription polymerase chain reaction } \\ \text { SARS-CoV-2 } & \text { Severe Acute Respiratory Syndrome Coronavirus 2 } \\ \text { SpO } & \text { Saturasi oksigen } \\ \text { T cell } & \text { Lymphocyte T cell } \\ \text { TNF } & \text { Tumor necrosis factor } \\ \text { TPA } & \text { Tempat pembuangan akhir } \\ \text { UV } & \text { Ultra violet } \\ \text { VEGFA } & \text { Vascular Endothelial Growth Factor A } \\ \text { WHO } & \text { World Health Organization } \\ \end{array}$


Tabel 1. Jumlah virus pada berbagai permukaan material. gigi.

Tabel 3. Spesifikasi high volume evacuator.

Tabel 4. Level APD berdasarkan tupoksi dalam ruang praktik dokter gigi.

Tabel 5. Rekapitulasi kebutuhan alat dan bahan minimal sesuai dengan level APD.

Tabel 6. Daftar disinfektan yang efektif untuk membunuh Human coronanvirus spesifik SARS-CoV-2.

Tabel 7. Tanda dan gejala COVID-19 menurut WHO Maret 2020.

Tabel 8. Klasifikasi gejala infeksi COVID-19. $\quad 61$

Tabel 9. Contoh rincian harga perlengkapan proteksi untuk praktik dokter gigi dan perawat gigi.

Tabel 10. Contoh ilustrasi perhitungan variable cost.

Tabel 11. Formulir pendataan kontak pasien COVID-19 menurut Kemenkes 27 Maret 2020. 


\section{DAFTAR GAMBAR}

Gambar 1. A. Struktur virus SARS-CoV-2 yang terdiri dari 4 struktur protein

hal antara lain: (S) Spike, yang terletak dipermukaan dan ter susun dari glikoprotein; (M) protein membrane; $(\mathrm{N})$ protein nukleokaspid; dan (E) protein envelope/selubung/sampul. RNA merupakan ribonucleic acid yang terdapat di dalam nukleokaspid (Li dkk, 2020); B. Pseudo-colour scanning electron micrograph dari SARSCoV-2 dalam sel manusia. Partikel virus (warna jingga) pada permukaan sel (warna biru).

Gambar 2. Ilustrasi jarak jangkauan partikel splatter, droplet dan aerosol

Gambar 3. Siklus virus SARS-CoV-2.

Gambar 4. Fase infeksi SARS-CoV-2 hingga timbul respon antibody 10

Gambar 5. Skema pathogenesis COVID-19 dan cytokine storm dan dampaknya 11 terhadap kerusakan fungsi organ.

Gambar 6. Simulasi arah aliran udara dalam ruang praktik dokter gigi. 18

Gambar 7. A. High volume evacuator yang terpasang langsung di dental unit. B. 20 High volume evacuator yang diluar dental unit.

Gambar 8. Pemisahan ruang antara ruang praktik dental unit, ruang donning dan doffing APD. Signage ruang donning dan doffing perlu dilekatkan di dinding untuk mengingatkan kewaspadaan APD.

Gambar 9a. Pengaturan ruang pelepasan APD.

Gambar 9b. Demarkasi zona dapat mencegah operator (tetapi bukan sarana prasarana) menyeberang dari zona bersih ke zona "kotor". (Merah = "tata laksana infeksius", Kuning= "kehati-hatian", dan Hijau = "Jalur bersih").

Gambar 10. Pegangan tangan saat doffing APD.

Gambar 11. Tanda demarkasi pembagian lokasi doffing. 25

Gambar 12. Separator wall (dinding penghalang) yang terpasang di meja dokter 26 gigi.

Gambar 13. Signage di kursi ruang tunggu agar pasien saling menjaga minimal 1 meter.

Gambar 14. Tempat sampah di ruang dental unit terdiri dari infeksius dan non infeksius. Tempat sampah infeksius dilapisi dengan kantong plastik warna kuning, sedangkan non infeksius dilapisi dengan kantong plastik warna selain kuning (contoh hitam). 


\section{DAFTAR GAMBAR}

hal

Gambar 15. A. Absorbent. B. dan C. Mouth prop. D. Throat shield. E. Benang retraksi.

Gambar 16. A. Rubber dam punch. B. Rubber dam forceps. C. Rubber dam frame

D. Dental floss. E. Rubber dam clamp. F. rubber dam sheet. G.Tisu kertas (diletakkan antara kulit dan rubber dam sheet, sehingga dapat menyerap saliva jika ada kebocoran saliva dari rubber dam). H. Rubber dam sheet yang menyatu dengan napkin dan frame.

Gambar 17. Teknik pemasangan clamp sebelum pemasangan rubber dam.

Gambar 18. Teknik pemasangan clamp bersamaan dengan rubber dam.

Gambar 19. Teknik pemasangan clamp setelah pemasangan rubber dam.

Gambar 20. Teknik split dam.

Gambar 21. Teknik bow.

Gambar 22. Tahapan pemasangan APD.

Gambar 23. Tahapan pelepasan APD.

Gambar 24. Spektrum cahaya ultraviolet. $\quad 55$

Gambar 25. Kotak tempat pembuangan limbah tajam. 56

Gambar 26. Ember bertutup sebagai tempat merendam linen atau baju hazmat 56 yang sudah digunakan.

Gambar 27. A. Thermal gun. B. Kamera pemindai termal. 59

Gambar 28. Alur diagram deteksi dan respon berdasarkan kriteria kasus 62 COVID-19.

Gambar 29. Forest plot panel hasil laboratorik dari pasien COVID-19. 63

Gambar 30. Salah satu tes rapid yang di gunakan di Indonesia. 64

Gambar 31. Alur seleksi pasien yang masuk ke ruang praktik dokter gigi. 65

Gambar 32. Poster etiket batuk.

$\begin{array}{ll}\text { Gambar 33. Poster menjaga jarak. } & 71\end{array}$

Gambar 34. Poster enam langkah mencuci tangan. $\quad 72$

Gambar 35. Poster hidup sehat di masa era new normal. 76 


\section{BAB I \\ PATOBIOLOGI VIRUS SARS-COV-2}

Epidemi atau wabah infeksi saluran pernapasan akut terjadi pertama kali di Wuhan, China pada 12 Desember 2019. Wabah ini disebabkan oleh spesies coronavirus baru, dari kelelawar yang diduga sebagai reservoir utama untuk transmisi virus ( $\mathrm{H}$. Li dkk, 2020). Pada 11 Februari 2020, virus ini diberi nama oleh International Committee on Taxonomy of Viruses (ICTV) sebagai Severe Acute Respiratory Syndrome Coronavirus 2 (SARS-CoV-2) (Giovanetti dkk, 2020; Paraskevis dkk, 2020). Selanjutnya WHO mengumumkan jenis penyakit tersebut dengan nama Coronavirus disease 2019/COVID-19. Dampak utama yang bersifat fatal dari penyakit ini adalah kemampuan transmisi yang cukup tinggi, dapat menginfeksi saluran pernafasan bagian bawah, menyebabkan pneumonia dengan gejala yang tampak ringan, dapat menyebabkan badai inflamasi (cytokine storm), gagal nafas hingga kematian (Chen dkk, 2020).

COVID-19 pertama dilaporkan di Indonesia pada tanggal 2 Maret 2020 sebanyak dua kasus (Worldmeter, 2020). Data 28 Juni 2020 melaporkan kasus yang terkonfirmasi COVID19 berjumlah 54.010 kasus dan 2.754 kasus kematian (Kementerian Kesehatan RI, 2020). Tingkat mortalitas COVID-19 di Indonesia adalah tertinggi di Asia Tenggara (Worldmeter, 2020).

Dikutip dari buku "Pedoman Pencegahan dan Pengendalian Coronavirus Disease (COVID-19)" yang diterbitkan per 27 Maret 2020 oleh Kemenkes RI menyatakan bahwa, karakteristik seseorang yang terinfeksi virus SARS-CoV-2 dapat dibagi menjadi 3 kelompok, yaitu Orang Tanpa Gejala (OTG), Orang Dalam Pemantauan (ODP) dan Pasien Dalam Pengawasan (PDP). Deskripsi kelompok tersebut adalah sebagai berikut (Kementerian Kesehatan RI, 2020):

1) Kelompok OTG ditandai apabila seseorang memiliki riwayat kontak yang erat dengan seseorang yang telah terkonfirmasi COVID-19, tidak memiliki gejala, namun memiliki risiko tertular dan/ menularkan.

2) Kelompok ODP adalah :

- $\quad$ Orang yang mengalami demam $\left(\geq 38^{\circ} \mathrm{C}\right)$ atau riwayat demam; atau gejala gangguan sistem pernapasan seperti pilek/sakit tenggorokan/batuk DAN tidak ada penyebab lain berdasarkan gambaran klinis yang meyakinkan DAN pada 14 hari terakhir sebelum timbul gejala memiliki riwayat perjalanan atau tinggal di negara/wilayah yang melaporkan transmisi lokal.

- Orang yang mengalami gejala gangguan sistem pernapasan seperti 
pilek/sakit tenggorokan/batuk DAN pada 14 hari terakhir sebelum timbul gejala memiliki riwayat kontak dengan kasus konfirmasi COVID-19.

3) Kelompok PDP adalah :

- $\quad$ Orang dengan Infeksi Saluran Pernapasan Akut (ISPA) yaitu demam ( $\left.\geq 38^{\circ} \mathrm{C}\right)$ atau riwayat demam; disertai salah satu gejala/tanda penyakit pernapasan seperti: batuk/sesak nafas/sakit tenggorokan/pilek/pneumonia ringan hingga berat DAN tidak ada penyebab lain berdasarkan gambaran klinis yang meyakinkan DAN pada 14 hari terakhir sebelum timbul gejala memiliki riwayat perjalanan atau tinggal di negara/wilayah yang melaporkan transmisi lokal.

- $\quad$ Orang dengan demam $\left(\geq 38^{\circ} \mathrm{C}\right)$ atau riwayat demam atau ISPA DAN pada 14 hari terakhir sebelum timbul gejala memiliki riwayat kontak dengan kasus konfirmasi COVID-19.

- $\quad$ Orang dengan ISPA berat/pneumonia berat yang membutuhkan perawatan di rumah sakit dan tidak ada penyebab lain berdasarkan gambaran klinis yang meyakinkan.

Berdasarkan hasil penelitian yang dilaporkan di China, prevalensi tertinggi terdapat pada kelompok OTG yaitu sebesar $86 \%$, diikuti dengan ODP $(11,4 \%)$, PDP (1,93\%), perawatan kritis (0,36\%) dan kematian (0,32\%) (CDC Weekly, 2020). Di Indonesia, berdasarkan data per 28 Juni 2020, prevalensi tertinggi terdapat pada kelompok ODP $(46,8 \%)$, diikuti dengan OTG $(35,9 \%)$, PDP $(14,7 \%)$ dan kematian $(2,7 \%)$ (Gugus-Tugas COVID-19, 2020). Namun, dari total 273.517 .000 penduduk Indonesia (Indonesia Population, 2020), belum semua penduduk Indonesia melakukan pemeriksaan COVID-19. Oleh sebab itu, potensi terjadinya penyebaran virus di lingkungan keluarga maupun di lingkungan kerja perlu diwaspadai.

Kontak erat adalah seseorang yang melakukan kontak fisik atau berada dalam ruangan atau berkunjung (dalam radius 1 meter dengan kasus pasien dalam pengawasan atau terkonfirmasi COVID-19) dalam 2 hari sebelum timbul gejala dan/hingga 14 hari setelah timbul gejala, sehingga yang termasuk dalam kategori kontak erat adalah:

1) Petugas kesehatan yang memeriksa, merawat, mengantar dan membersihkan ruangan di tempat perawatan kasus tanpa menggunakan APD sesuai standar.

2) Orang yang berada dalam suatu ruangan yang sama dengan kasus (termasuk tempat kerja, kelas, rumah, acara besar) dalam 2 hari sebelum timbul gejala dan/hingga 14 hari setelah timbul gejala. 
3) Orang yang bepergian bersama (radius 1 meter) dengan segala jenis alat angkut/kendaraan dalam 2 hari sebelum timbul gejala dan/hingga 14 hari setelah timbul gejala.

Pada tahun 1966, Hall telah mengklasifikasikan 4 zona ruang atau radius

berdasarkan aktivitas seseorang dalam lingkungan sosial, yaitu:

1) Jarak intim dengan radius $0-45 \mathrm{~cm}$

2) Jarak personal dengan radius $60-120 \mathrm{~cm}$

3) Jarak sosial dengan radius $1,2-3 \mathrm{~m}$

4) Jarak publik dengan radius $>3 \mathrm{~m}$

Dari keempat kategori tersebut, sebagian besar prosedur perawatan atau penatalaksanaan di bidang kedokteran gigi, termasuk pada kategori jarak intim (Micik dkk, 1969). Selain jarak yang cukup dekat antara dokter gigi dan pasien, prosedur kedokteran gigi juga dapat memproduksi pembentukkan aerosol dalam jumlah yang massif, sehingga dapat menularkan orang lain (pasien, keluarga, tenaga kesehatan lain dan lingkungan sekitar). Dengan demikian, dokter gigi merupakan salah satu profesi berisiko tinggi terhadap penularan dan penyebaran virus SARS-CoV-2. (OSAP/DQP, 2020).

Sebagian besar risiko penularan terjadi saat terdapat percikan (splatter, droplet dan aerosol), ke tubuh atau wajah dokter gigi, asisten dan pasien (Nejatidanesh dkk, 2013). Penularan melalui prosedur non-bedah yang menghasilkan partikel aerosol, antara lain berasal dari ultrasonic/sonic scaller, atau handpiece atau three way syringe (Harrel dan Molinari, 2004). Selain itu, Asadi dkk melaporkan bahwa, aktivitas berbicara dalam proses konsultasi berpotensi mengeluarkan 1-50 partikel aerosol/detik (Asadi dkk, 2019). Oleh sebab itu, penting bagi dokter gigi untuk mengetahui karakteristik dari virus SARS-CoV-2 dan standar pencegahan transmisinya selama penatalaksanaan praktik kedokteran gigi di era new normal.

\section{A. Karakteristik Virus SARS-CoV-2}

Virus SARS-CoV-2 merupakan virus RNA yang memiliki sampul/selubung, positivesense yang berasal dari subfamily Orthocoronavirinae, family Coronaviridae, order Nidovirales. Subfamily Orthocoronavirinae, memiliki 4 genus yang terdiri dari Alphacoronavirus ( $\alpha-\mathrm{CoV})$, Betacoronavirus $(\beta-\mathrm{CoV})$, Gammacoronavirus $(\gamma-\mathrm{CoV})$ and Deltacoronavirus ( $\delta$-CoV) (Li dkk, 2020). Dari keempat genus tersebut, SARS-CoV-2 merupakan species dari genus $\beta$-CoV. Virus ini dapat diisolasi di kelompok mamalia seperti manusia. Struktur virus SARS-CoV-2 dapat dilihat pada gambar 1. 


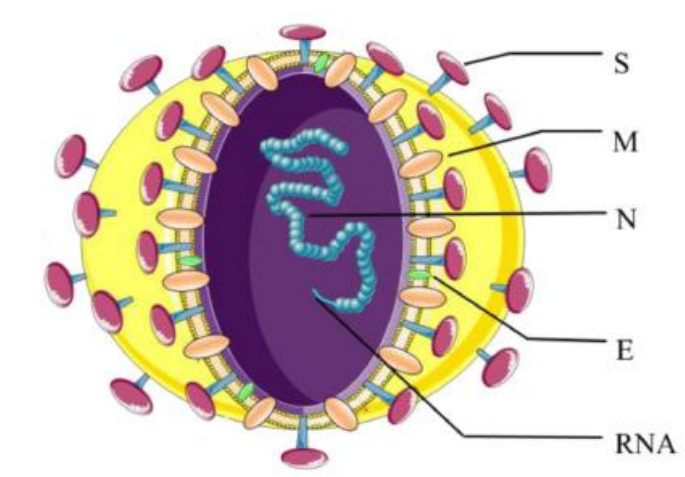

A

\section{B}

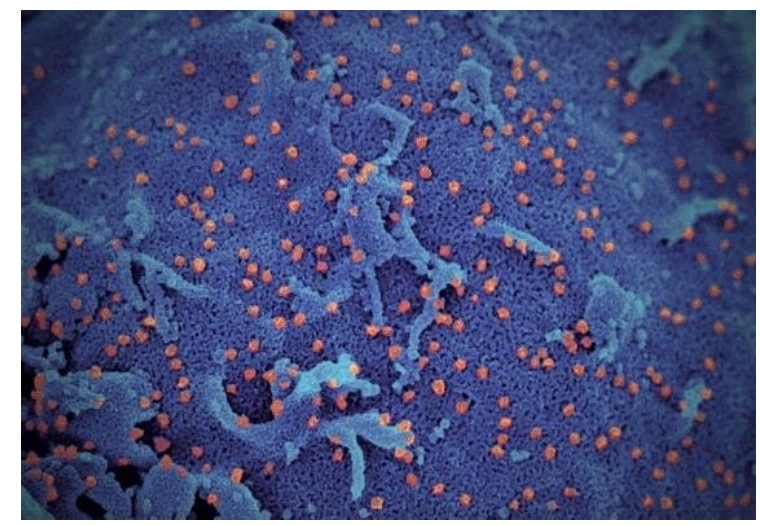

Gambar 1. A. Struktur virus SARS-CoV-2 yang terdiri dari 4 struktur protein antara lain: (S) Spike, yang terletak dipermukaan dan tersusun dari glikoprotein; $(M)$ protein membrane; $(N)$ protein nukleokaspid; dan (E) protein envelope/selubung/ sampul. RNA merupakan ribonucleic acid yang terdapat di dalam nukleokaspid (Li dkk, 2020); B. Pseudo-colour scanning electron micrograph dari SARS-CoV-2 dalam sel manusia. Partikel virus (warna jingga) pada permukaan sel (warna biru) (Tsia dkk, 2020).

\section{B. Penularan/Transmisi Virus}

WHO dan CDC menyatakan bahwa, infeksi saluran pernafasan dapat ditransmisikan melalui partikel berdasarkan ukurannya, yaitu splatter yang berukuran $>50 \mu \mathrm{m}$ (Harrel $\mathrm{dkk}, 2004)$, droplet yang berukuran $>10 \mu \mathrm{m}$, dan partikel aerosol yang berukuran 0.3-10 $\mu \mathrm{m}$. WHO-CDC juga mengakui ketiga bentuk transmisi tersebut sebagai moda transmisi dari virus SARS-CoV-2 (WHO, 2014). Ilustrasi sebaran splatter, droplet dan aerosol dapat dilihat pada gambar 2 .

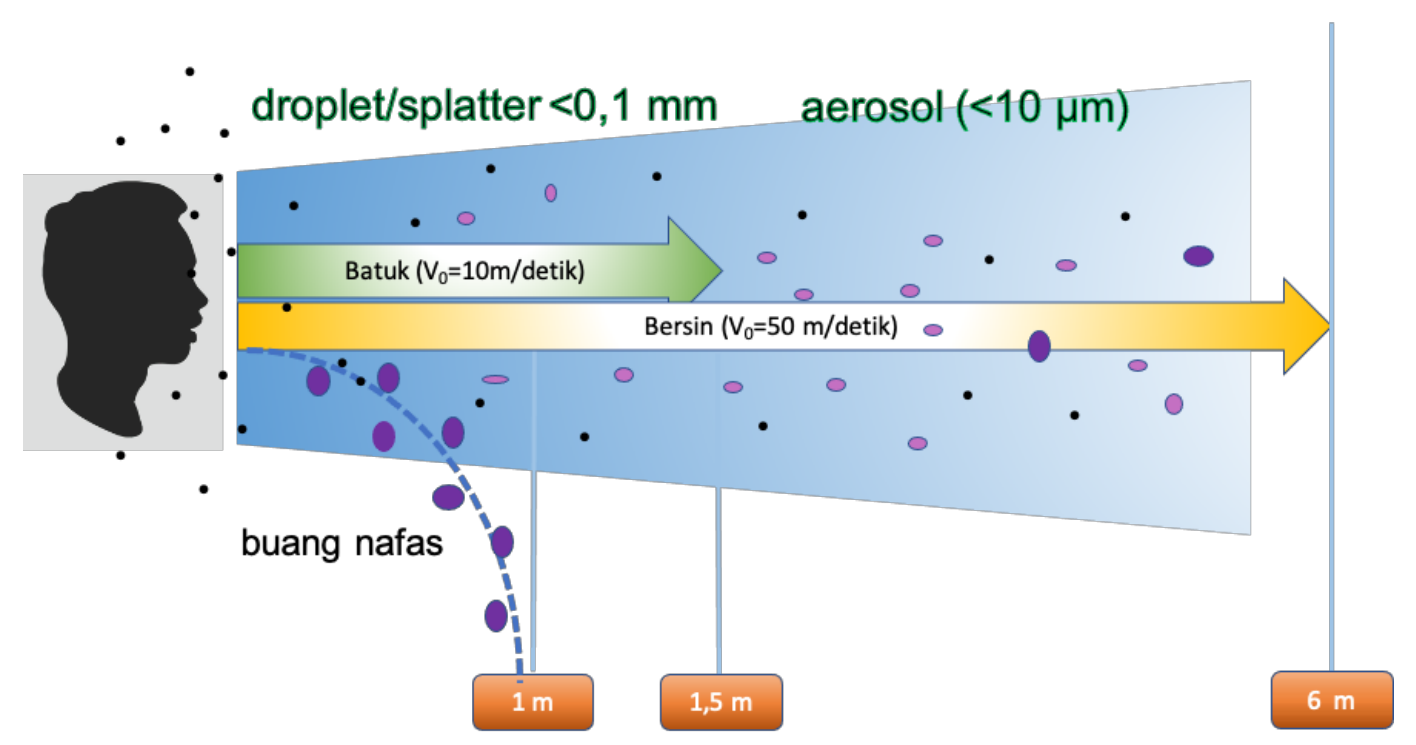

Gambar 2. Ilustrasi jarak jangkauan partikel splatter, droplet dan aerosol (modifikasi ilustrasi dari Froum dan Strange, 2020) 


\section{Cara transmisi}

\section{a. Splatter}

Virus SARS-CoV-2 dapat bertransmisi diantara manusia melalui splatter/ percikan cairan yang keluar ketika berbicara. Splatter bersifat balistik karena diproduksikan dengan kekuatan tertentu dari suatu tempat ke tempat lain seperti lintasan peluru, hingga menyentuh permukaan. Partikel ini berukuran lebih besar dari droplet, dapat bertahan di udara dalam waktu singkat dan menjangkau area berjarak < $1 \mathrm{~m}$ (Harrel dkk, 2004).

\section{b. Droplet}

Droplet dapat disebut dengan istilah "respiratory droplet". Droplet merupakan partikel yang berat dan tidak dapat berpindah lebih jauh dari 1,5 m (WHO, 2014). Ukuran droplet akan berangsur menjadi kecil dan bertahan di udara. Ketika jarak seseorang berada pada radius 1-1,5 m dan terdapat aktivitas berbicara, batuk atau bersin dari orang yang memiliki gejala gangguan pernafasan, maka akan terjadi transmisi droplet melalui hidung, mulut atau mata (organ yang berpotensi terekspos oleh virus SARS-CoV-2).

c. Aerosol

Aerosol memiliki terminologi yang sama dengan istilah "bio-aerosol" atau "droplet nuclei". Aerosol terbentuk oleh partikel padat atau cair, tersebar dan dapat bertahan di udara (Wang dkk, 2020). Virus yang terdapat pada partikel aerosol ini dapat bertransmisi melalui batuk, bersin, berbicara, bernafas yang cepat, atau perawatan gigi. Menurut Olsen dkk (2003) kelompok virus SARS-CoV pada partikel aerosol, dapat berpindah pada jarak yang jauh dengan estimasi radius $1 \mathrm{~m}$ secara horizontal (Olsen dkk, 2003). Partikel aerosol umumnya berdiameter 0,3 hingga $10 \mu \mathrm{m}$. Beberapa penelitian lain menemukan bahwa partikel berukuran 1-10 $\mu \mathrm{m}$ dapat terhirup dan bertahan di udara hingga 3 jam (Froum dan Strange, 2020; van Doremalen dkk, 2020). Kampf dkk (2020) juga melaporkan bahwa kelompok virus SARS-CoV dapat bertahan hidup di permukaan material tertentu pada suhu ruang, seperti yang tertera pada tabel 1 (Kampf dkk, 2020).

Tabel 1. Jumlah virus pada berbagai permukaan material (Kampf dkk., 2020).

\begin{tabular}{ccc}
\hline Jenis material & Jumlah virus & Waktu \\
\hline Besi & $10^{5}$ & 5 hari \\
Kayu & $10^{4}$ & 4 hari \\
Kertas & $10^{4}-10^{6}$ & $<3$ menit -5 hari \\
Kaca & $10^{5}$ & 4 hari \\
Plastik & $10^{5}$ & 4 hari \\
Disposable gown & $10^{4}-10^{6}$ & 1 jam -2 hari \\
\hline
\end{tabular}


Seperti yang telah disebutkan, dokter gigi termasuk dalam kategori profesi yang berisiko tinggi terhadap transmisi virus SARS-CoV-2. Penilaian tingkat risiko dalam tata laksana kedokteran gigi didasari oleh potensi terhadap paparan, dari tindakan yang diketahui atau diduga mengandung SARS-CoV-2. Tindakan tersebut berpotensi menghasilkan aerosol seperti penggunaan handpiece berkecepatan tinggi atau rendah, ultrasonic scaller, three-ways syringe dan pemolesan. Occupational Safety and Health Administration (OSHA) kemudian menetapkan tingkat risiko sebagai berikut (OSAP/DQP, 2020). Tabel 2 menunjukkan kategori risiko dari tindakan dokter gigi.

Tabel 2. Tingkat risiko dokter gigi dalam menjalankan prosedur kedokteran gigi.

\begin{tabular}{|c|c|}
\hline $\begin{array}{l}\text { RISIKO RENDAH } \\
\text { Tidak ada kontak dengan pasien, asisten dokter gigi } \\
\text { atau kontak langsung pada aerosol. } \\
\text { Tindakan: } \\
\text { Preventif : } \\
\text { - Instruksi untuk menjaga dan meningkatkan } \\
\text { kebersihan rongga mulut dan diet pasien } \\
\text { Diagnostik: } \\
\text { - Konsultasi } \\
\text { - Pemeriksaan radiografi ekstraoral (Panoramic, } \\
\text { Cephalometric atau gambaran radiografis } \\
\text { lainnya) }\end{array}$ & $\begin{array}{l}\text { RISIKO SEDANG } \\
\text { Adanya kontak dekat tapi minimal, tanpa aerosol } \\
\text { (tanpa menggunakan three-way syringe). } \\
\text { Tindakan: } \\
\text { Preventif : } \\
\text { - } \quad \text { Aplikasi fluoride } \\
\text { Diagnostik: } \\
\text { - Pemeriksaan klinis } \\
\text { - } \quad \text { Radiografi intraoral } \\
\text { Kuratif: } \\
\text { - Tindakan emergensi seperti drainase abses } \\
\text { - } \quad \text { Teknik restorative atraumatic } \\
\text { - } \quad \text { Pencabutan gigi sederhana } \\
\text { - } \quad \text { Kontrol pasca operasi } \\
\text { - } \quad \text { Kontrol alat ortodontis } \\
\text { - Pencetakan model studi }\end{array}$ \\
\hline $\begin{array}{l}\text { RISIKO TINGGI } \\
\text { Melibatkan prosedur aerosol pada pasien secara } \\
\text { terkontrol. } \\
\text { Tindakan : } \\
\text { Preventif : } \\
\text { - } \quad \text { Scalling manual } \\
\text { - } \quad \text { Pemolesan yang terkontrol dengan penggunaan } \\
\text { - } \quad \text { pasta yang minimal, } \\
\text { Kuratif : } \\
\text { - } \quad \text { Insersi/sementasi implant endodontik } \\
\text { - } \quad \text { Restorasi dan prosedur disertai pemakaian } \\
\text { rubber dam, } \\
\text { - Scalling dan root planning manual } \\
\text { - } \quad \text { Kuretase gingiva yang terkontrol } \\
\text { - Penggunaan handpiece grinding ekstra- oral } \\
\text { - } \quad \text { Prosedur gigi tiruan tanpa penyesuaian } \\
\text { intraoral (misalnya tindakan koreksi oklusi } \\
\quad \text { harus dikerjakan ekstraoral), sehingga semua } \\
\text { alat/protesa yang telah dimasukkan ke dalam } \\
\text { mulut pasien, harus disinfeksi. }\end{array}$ & $\begin{array}{l}\text { RISIKO SANGAT TINGGI } \\
\text { Melibatkan prosedur aerosol pada pasien } \\
\text { yang sulit dikendalikan. } \\
\text { Tindakan: } \\
\text { Preventif : } \\
\text { - } \quad \text { Scalling dengan meggunakan sonic/ ultra-sonic } \\
\text { - } \quad \text { Kuratif : } \\
\text { - Perbaikan titik kontak } \\
\text { - Occlusal adjustment } \\
\text { - Pemakaian high-/low-speed handpiece } \\
\text { - Preparasi gigi-restorasi gigi } \\
\text { - } \quad \text { Three-way syringe } \\
\text { (Semua tindakan diatas yang dilaksanakan tanpa } \\
\text { rubber dam) } \\
\text { Catatan: Tindakan PSA (Perawatan Saluran Akar) } \\
\text { wajib menggunakan rubber dam. }\end{array}$ \\
\hline
\end{tabular}




\section{Patogenesis}

Patogenesis COVID-19 masih ditelusuri. Namun beberapa penelitian melaporkan bahwa jalur masuknya virus SARS-CoV-2 diketahui sama dengan jalur masuk virus SARS-CoV-1, yaitu spike virus SARS-CoV-2 akan berikatan dengan reseptor Angiotensin Converting Enzyme 2 (ACE2) dari sel inang. ACE2 merupakan reseptor utama yang dilaporkan pada sejumlah penelitian karena memiliki afinitas yang tinggi terhadap protein spike SARS-CoV-2. Ikatan tersebut memfasilitasi virus SARS-CoV-2 untuk masuk ke dalam sel inang, dan bereplikasi (Hui dkk, 2020; Zhou dkk, 2020)

Masuknya virus SARS-CoV-2 ke dalam sel inang dapat melalui endositosis yaitu masuknya virus ke dalam sel dengan cara membentuk kantung dari membran plasma, atau melalui fusi membran antara selubung virus dan membran plasma (Gambar 3) (Shereen dkk, 2020). Setelah bereplikasi, virus akan keluar dari sel inang dengan cara eksositosis dan mulai menginfeksi sel (yang memiliki reseptor terhadap virus SARS-CoV-2) pada organ lain dari tubuh.

ACE2 banyak terdapat di permukaan sel epitel saluran pernafasan maupun di epitel mukosa mulut. Pada rongga mulut, ACE2 banyak ditemukan pada mukosa mulut, seperti lidah, mukosa bukal, gingiva ( $X u$ dkk, 2020) dan sel epitel yang terdapat di duktus kelenjar saliva (Liu dkk, 2011). Selain ACE2, beberapa penelitian terkini menemukan adanya reseptor lain dari sel inang yang mampu berikatan dengan spike SARS-CoV, yaitu Cluster of Differentiation 147 (CD147) (Dayakar dkk, 2016) dan transmembrane serine protease 2 (TMPRSS2) (Pedrosa dkk, 2020). Kedua reseptor ini terdistribusi di rongga mulut baik di jaringan periodontal maupun di area kelenjar saliva.

\section{a. Metode pemeriksaan COVID-19}

Metode pemeriksaan untuk diagnosis COVID-19 masih terus dikembangkan. WHO merekomendasikan 2 jenis pemeriksaan yaitu, dengan menggunakan Rapid Test dan Reverse Transcriptase Polymerase Chain Reaction (RT-PCR) (WHO COVID-19, 2020). Aplikasi dari kedua tes diagnostik tersebut perlu didasari dengan pemahaman yang tepat mengenai prinsip kerja alat serta interpretasinya. Pada prinsipnya, rapid test dibagi menjadi 2 yaitu berdasarkan antibodi dan antigen. Rapid test berdasarkan antibodi adalah tes diagnosik yang umum digunakan saat ini. Mengacu pada penggunaannya, rapid test antibodi bertujuan untuk mendeteksi ada/tidaknya antibodi terhadap virus SARS-CoV-2. Berbeda dengan rapid 
test, RT-PCR digunakan untuk mendeteksi keberadaan virus serta jumlahnya. Oleh sebab itu, rapid test umumnya digunakan sebagai screening test, sedangkan RT-PCR saat ini digunakan sebagai confirmation test.

Berdasarkan waktu perjalanan penyakit, Sethuraman (2020) mengklasi-fikasikan menjadi 2 tahapan waktu, yaitu before symptom onset (sebelum gejala klinis timbul), dan after symptom onset (setelah gejala klinis timbul). Before symptom onset diperkirakan pada minggu 1-2 (14 hari) setelah terekspos virus, sedangkan after symptom onset dimulai pada hari-14 setelah fase sebelum gejala klinis timbul.

Pada hari 1 ketika seseorang terpapar virus SARS-CoV-2, maka seseorang tersebut bisa dikatakan telah terinfeksi walau tidak menunjukkan gejala. Pada saat ini, pemeriksaan rapid test belum akurat karena belum terbentuk antibodi, namun deteksi virus sudah dapat dilakukan melalui pemeriksaan RT-PCR. Hal ini disebabkan karena RT-PCR merupakan metode deteksi molekuler yang ditujukan pada materi genetik virus, yaitu RNA. Namun, hasil RT-PCR juga dapat dipengaruhi oleh beberapa faktor seperti metode ekstraksi RNA, tipe reagen, laboran, termasuk proses pengambilan dan penyimpanan sampel. Beberapa penelitian menyatakan bahwa hasil positif RT-PCR dapat terdeteksi dari seseorang yang baru terinfeksi virus yaitu pada hari 1 (Lee dkk, 2020), sedangkan penelitian lain mendeteksi positif RT-PCR di hari ke-7 hingga hari ke-14. Virus yang berhasil masuk ke dalam sel inang akan melepaskan materi genetiknya berupa RNA ke dalam sitoplasma sel, selanjutnya bereplikasi hingga menimbulkan gejala. Rentang waktu inilah disebut sebagai masa inkubasi virus (Sethuraman dkk, 2020). Kedua hasil penelitian tersebut membuktikan bahwa RT-PCR dapat digunakan untuk mendeteksi adanya virus SARS-CoV-2 pada fase awal infeksi. Jumlah virus yang meningkat pada rentang waktu tersebut menunjukkan adanya aktivitas replikasi virus yang tinggi. Ketika memasuki minggu ke-3 pemeriksaan dengan RT-PCR menunjukkan jumlah virus SARSCoV-2 mulai menurun.

Sebagai antigen, kehadiran virus akan memicu terbentuknya antibodi atau immunoglobulin oleh sel-sel limfosit B sebagai salah satu dari sistem imun. Berdasarkan struktur karakteristik dan sifatnya, antibodi diklasifikasikan menjadi 5 jenis yaitu immunoglobulin M (IgM), IgG, IgA, IgE, dan IgD. Dari kelima jenis antibodi tersebut, IgM dan IgG merupakan indikator yang dipakai pada pemeriksaan rapid test COVID-19 saat ini. 
Namun, beberapa penelitian juga melaporkan adanya peningkatan level IgA pada pasien COVID-19. Prinsip dari peran antibodi IgG, IgM, dan IgA terkait diagnosis COVID-19 akan dijabarkan singkat sebagai berikut (Jacofsky dkk, 2020):

1) IgM memiliki $10 \%$ dari seluruh antibody, dan dapat ditemukan di dalam darah. Ketika antigen masuk ke dalam sel inang, antibodi yang pertama kali diproduksi oleh sel limfosit B adalah IgM. IgM akan meningkat pada fase awal perkembangan infeksi akut. Beberapa penelitian melaporkan bahwa IgM dapat terdeteksi melalui rapid test, 4 hari setelah timbul gejala COVID-19 (Sethuraman dkk, 2020). Meskipun IgM memiliki afinitas (kekuatan mengikat) terhadap antigen yang lebih rendah dibandingkan IgG, namun IgM memiliki aviditas (kecenderungan untuk mengikat antigen) yang tinggi, karena struktur IgM adalah pentametric (memiliki 5 area antigen binding). Sehingga IgM dapat berikatan lebih banyak dengan antigen dibandingkan dengan antibodi lainnya. Jumlah IgM akan meningkat pada minggu ke-2 setelah timbul gejala dan menurun jumlahnya ketika memasuki minggu ke-3.

2) IgG memiliki presentasi $70-75 \%$ dan juga banyak ditemukan di dalam darah. IgG akan berikatan dengan antigen, sehingga mampu dikenali oleh sel leukosit dan makrofag sebagai benda asing yang harus dihancurkan. IgG akan diproduksi oleh sel limfosit B, 5 hari setelah muncul gejala dan dapat bertahan lebih dari beberapa minggu hingga beberapa bulan.

3) IgA dapat ditemukan sebanyak $10-15 \%$ di dalam tubuh, dan terdistribusi di serum, mukosa, bahkan di saliva. Penelitian terakhir melaporkan bahwa, peningkatan jumlah antibodi IgA ditemukan pada pasien COVID-19. Oleh sebab itu, IgA yang terdapat di saliva sangat potensial sebagai indikator tes serologi infeksi COVID-19 (Amanat dkk, 2020) 


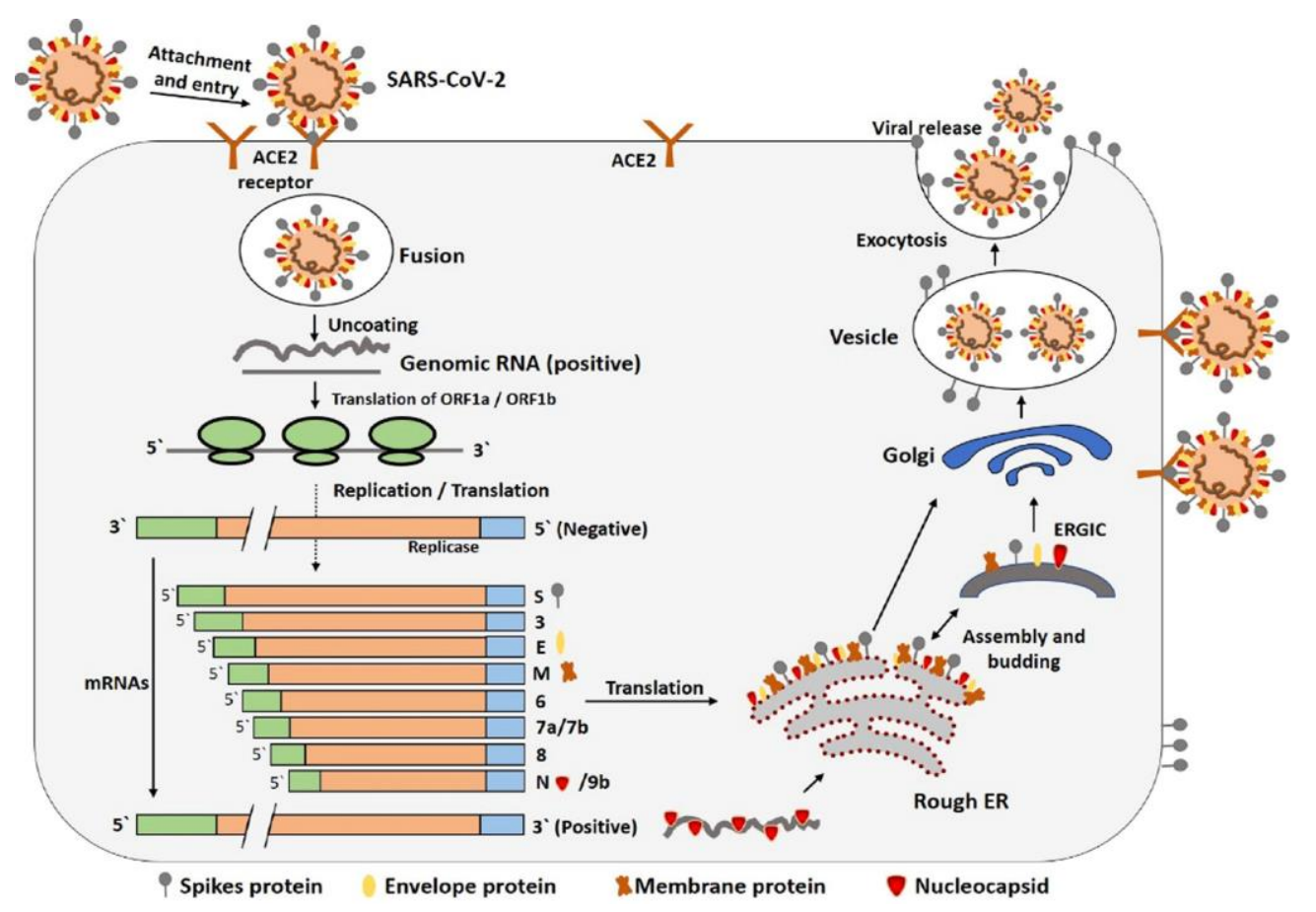

Gambar 3. Siklus virus SARS-CoV-2.(Shereen dkk, 2020)

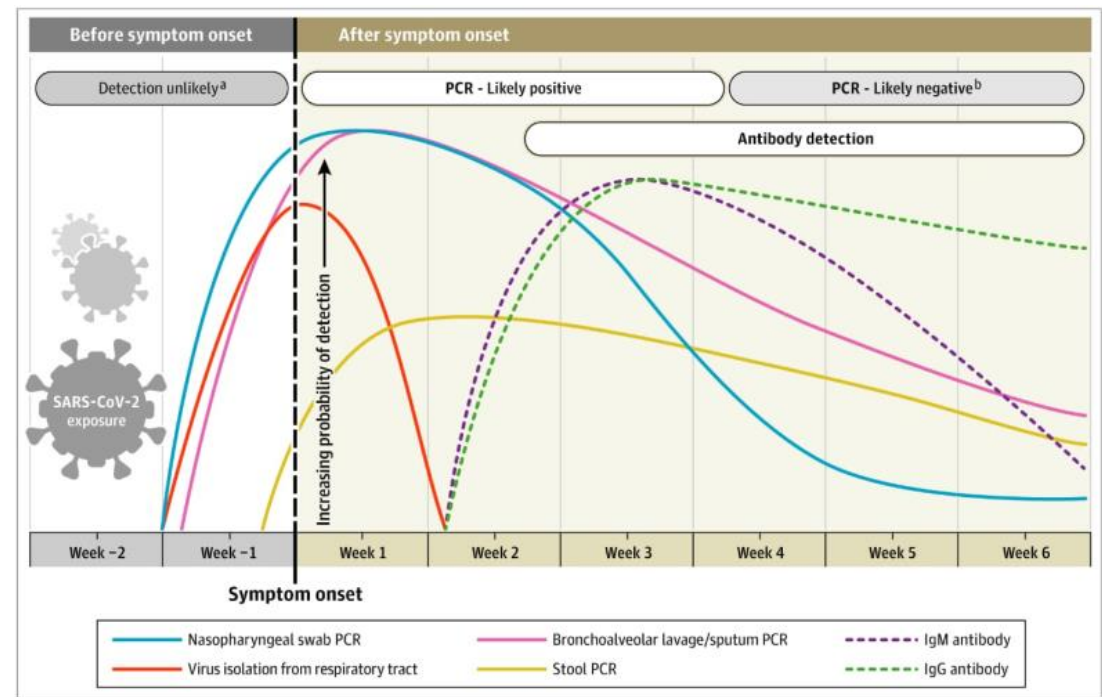

Gambar 4. Fase infeksi SARS-CoV-2 hingga timbul respon antibodi (Sethuraman, dkk, 2020)

\section{b. Fase infeksi SARS-CoV-2}

Infeksi virus SARS-CoV-2 dapat dibagi menjadi 3 fase (Nile dkk, 2020) yaitu:

1) Tanpa gejala (yang bermanifestasi pada kelompok OTG).

2) Gejala ringan yang disertai dengan gangguan saluran nafas atas. 
3) Gejala berat yang berpotensi mematikan disertai hipoksia, infiltrasi ground glass opacity (GGO) pada paru-paru dan berkembang menjadi Acute Respiratory Distres Syndrome (ARDS) dengan jumlah virus yang tinggi.

\section{c. Cytokine Storm}

Salah satu fitur utama dari ARDS adalah cytokine storm. Cytokine storm merupakan respon inflamasi sistemik yang tidak terkendali, yang dihasilkan dari pelepasan sitokin dan kemokin proinflamasi secara imun sel efektor ( $\mathrm{Li}$ dkk, 2020). Pada pasien COVID-19, kadar sitokin dan kemokin yang ditemukan sangat tinggi, yaitu IL1- $\beta$, IL1RA, IL7, IL8, IL9, IL10, basic FGF2, GCSF, GMCSF, IFN $\gamma$, IP10, MCP1, MIP1 $\alpha$, MIP1 $\beta$, PDGFB, TNF $\alpha$, dan VEGFA (Rothan dan Byrareddy, 2020). Selanjutnya cytokine storm akan memicu respon inflamasi yang berkontribusi pada terjadinya ARDS, dengan adanya kegagalan pada berberapa fungsi organ (seperti paru-paru, jantung, ginjal dan hati) hingga kematian. Pasien yang terinfeksi COVID-19 juga menunjukkan adanya jumlah leukosit yang tinggi. Skema patogenesis COVID19 dapat dilihat pada gambar 5 .

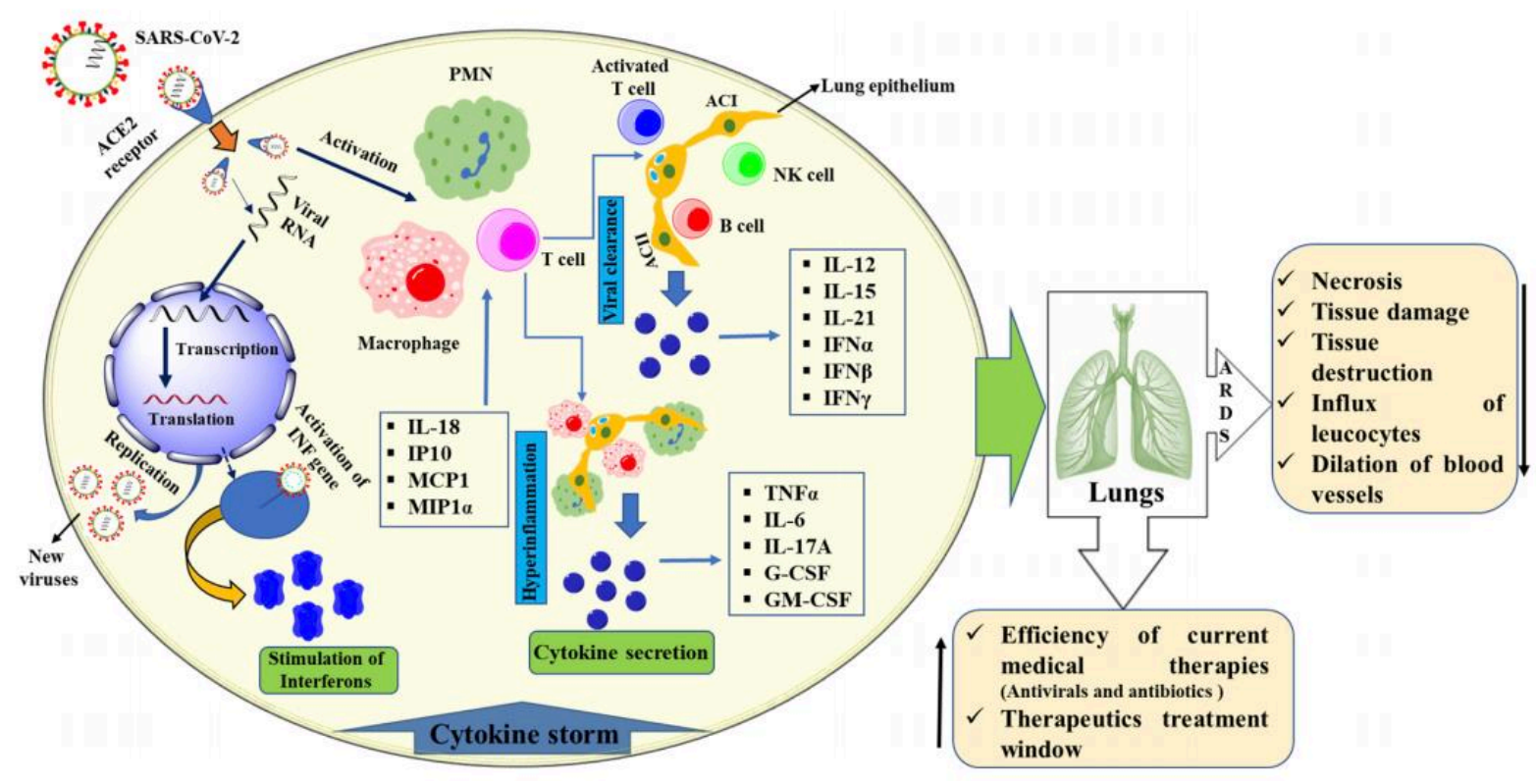

Gambar 5. Skema patogenesis COVID-19 dan cytokine storm dan dampaknya terhadap kerusakan fungsi organ (Nile dkk, 2020). 


\section{Virus SARS-CoV-2 Dalam Saliva}

Dengan ditemukannya reseptor sel inang yang dapat berikatan dengan virus SARS-CoV-2 di rongga mulut, maka dapat dijumpai korelasi dengan jumlah virus yang terdeteksi. Jumlah virus yang terkandung di dalam saliva memiliki konsentrasi yang tinggi yaitu sebanyak 1-1,2 x108 copies/mL dan dapat terdeteksi pada awal gejala infeksi virus (Tsang dkk, 2020). Oleh sebab itu, pendekatan diagnosis melalui sample saliva masih perlu diteliti lebih lanjut. Walau demikian dapat disimpulkan bahwa rongga mulut sangat berpotensi dan rentan terhadap infeksi virus SARS-CoV-2 (Xu dkk, 2020) 


\section{BAB II \\ RUANGAN PRAKTIK}

Pembagian zonasi ruang dalam fasilitas pelayanan kesehatan bidang kedokteran gigi sangat diperlukan pada era new normal. Pembagian zonasi kuning dan merah. Selain zonasi perlu diperhatikan arah alur pergerakan pasien dan pergerakan tenaga medis harus teridentifikasi jelas, diatur dengan sign/tanda khusus yang dapat dipahami dengan baik. Alur pergerakan pasien dari mulai masuk fasilitas pelayanan kesehatan harus di atur agar selalu menjaga jarak dan kepadatan. Alur pergerakan tenaga medis baik dokter gigi, dan asisten yang beraktifitas di dalam ruang praktik harus dibuat khusus dan terdapat jalur ke ruang ganti atau dekontaminasi yang dibuat tidak bertemu dengan petugas atau ruang tunggu pasien secara langsung. Pengaturan ruang praktik dokter gigi sangat perlu memperhatikan aliran udara di dalam ruang.

\section{A. Aliran Udara}

Pandemi COVID-19 mengharuskan perubahan kebiasaan dan tatanan dalam praktik bidang Kedokteran Gigi. Perubahan tatanan memerlukan penambahan pembiayaan akibat dari penyesuaian yang harus dilakukan oleh dokter gigi. Panduan ini dibuat berdasarkan beberapa referensi berbasis evidence based dentistry. Dokter gigi diharapkan dapat menyesuaikan kebutuhan perubahan-perubahan tersebut sesuai kondisi di tempat praktiknya masing-masing, tanpa mengesampingkan keamanan terhadap kontaminasi coronavirus yang bisa terjadi.

Pengaturan alur pelayanan dengan memperhatikan hubungan antar ruangan dan potensi risiko infeksi. Idealnya alur pelayanan satu arah dari bersih ke kotor. Ventilasi bangunan memiliki tiga elemen dasar:

1) Tingkat ventilasi - jumlah udara luar yang disediakan ke dalam ruang, dan kualitas udara luar.

2) Arah aliran udara - arah aliran udara keseluruhan dalam suatu bangunan, yang seharusnya berasal zona bersih ke zona kotor.

3) Distribusi udara atau pola aliran udara - udara eksternal (luar) harus dialirkan ke setiap bagian ruang secara efisien dan polutan udara yang dihasilkan di setiap bagian ruang juga harus dihilangkan secara efisien.

Ada tiga metode yang dapat digunakan untuk ventilasi bangunan: alami, mekanis dan ventilasi hybrid (mode campuran). 
Rekomendasi WHO yang berkaitan dengan persyaratan ventilasi:

1) Ventilasi yang memadai pada semua area fasilitas pelayanan kesehatan untuk membantu mencegah infeksi yang ditularkan melalui udara, yaitu menggunakan bahan aliran udara bersih untuk masuk ke dalam ruangan, di ikuti dengan model sirkulasi yang diatur bisa mengeluarkan sirkulasi udara dalam ruangan tersebut untuk dikeluarkan menggunakan penyedot yang mempunyai tekanan khusus (exhauster). Rekomendasi 1 ini mendapatkan rekomendasi kategori kuat dari WHO.

Perlu diperhatikan: terdapat bukti ilmiah yang menunjukkan bahwa ventilasi yang tidak memadai sangat berkaitan dengan meningkatnya risiko penularan infeksi sehingga diperlukan penggunaan ventilasi yang tepat untuk pengendalian infeksi melalui udara.

2) Penggunaan ventilasi alami mendapatkan rekomendasi bersyarat dari WHO, dengan tata aliran ventilasi rata-rata minimum per jam seperti berikut harus tersedia:

a) $160 \mathrm{~L} / \mathrm{dt} /$ pasien (tingkat ventilasi rata-rata per jam) untuk ruang tindakan pencegahan melalui udara (perhatikan bahwa ini hanya berlaku untuk fasilitas layanan kesehatan baru dan yang melakukan renovasi besar);

b) $80 \mathrm{~L} / \mathrm{dt} /$ pasien untuk ruang poli rawat jalan non aerosol; dan

c) $2,5 \mathrm{~L} / \mathrm{dt} / \mathrm{m} 3$ untuk koridor dan ruang tunggu sementara tanpa jumlah pasien yang tetap; Namun, ketika perawatan pasien dilakukan di koridor selama keadaan darurat atau situasi lain, persyaratan tingkat ventilasi yang sama untuk ruang pencegahan udara atau bangsal umum akan berlaku.

d) Desain harus memperhitungkan fluktuasi tingkat ventilasi (=perputaran aliran udara).

e) Ketika ventilasi alami saja tidak dapat memenuhi persyaratan ventilasi yang disarankan, sistem ventilasi alternatif, seperti sistem ventilasi alami hybrid (mode campuran), harus dipertimbangkan, dan kemudian jika itu tidak cukup, ventilasi mekanis harus digunakan.

Perlu diperhatikan: Penerapan ventilasi alami tergantung pada kondisi iklim yang menguntungkan.

3) Ketika merancang fasilitas pelayanan kesehatan menggunakan sistem ventilasi alami, maka keseluruhan aliran udara harus membawa udara dari sumber-sumber dari daerah bersih di mana volume aliran udara bersih akan bercampur cukup baik dengan udara di dalam ruangan. WHO tetap 
memberikan kategori bersyarat untuk poin 3 ini.

Perlu diperhatikan: Meskipun beberapa bukti menunjukkan kemungkinan adanya hubungan antara arah aliran udara dengan penyebaran infeksi di udara, ternyata penyebaran tersebut dapat terjadi pada tingkat aliran ventilasi udara yang sangat rendah (lebih rendah dari 4 air changes hour/ACH). Dapat disimpulkan bahwa jika tingkat aliran ventilasi udara di ruang cukup tinggi, maka risiko penyebaran infeksinya juga akan minimal. Namun, seberapa besar tingkat aliran ventilasi udara pada ruang tertutup yang tepat diperlukan untuk risiko penyebaran belum diketahui. Penerapan aliran ventilasi alami sangat tergantung pada kondisi iklim yang sesuai.

4) Untuk ruang prosedur tindakan yang menghasilkan aerosol dengan transmisi patogen maka persyaratan ventilasi alami harus mengikuti rekomendasi aliran udara pada poin 1, dan jika bersifat airborne maka rekomendasi pada poin 1, 2 dan 3 harus diikuti.

Perlu diperhatikan: bahwa terdapat bukti tidak langsung yang menunjukkan bahwa beberapa prosedur tindakan yang menghasilkan aerosol berkaitan dengan peningkatan risiko penularan infeksi. Jumlah aliran ventilasi udara sangat berperan, sehingga diperlukan penelitian dan perhitungan lebih lanjut untuk penetapan seberapa aliran ventilasi udara minimum untuk ruangan tindakan yang menghasilkan aerosol.

Meskipun masih memerlukan penelitian lebih lanjut, rekomendasi yang ditetapkan untuk aliran udara tingkat ventilasi mekanik yang direkomendasikan saat ini adalah >12 ACH untuk ruang zona merah infeksius (CDC, 2020). Berdasarkan hal tersebut maka disarankan bahwa jika menggunakan ventilasi alami untuk pengendalian infeksi, maka tingkat aliran ventilasi minimum harus lebih tinggi dari persyaratan yang ada untuk ventilasi mekanis diatas. Hal ini untuk mengimbangi fluktuasi yang mungkin timbul dan kesulitan dalam mengendalikan arah aliran udara.

Pedoman WHO menyarankan penggunaan volume ruangan, tingkat aliran ventilasi udara dalam hitungan liter per detik per pasien atau L/detik/pasien atau $\mathrm{L} / \mathrm{s} / \mathrm{p}$. Berbeda dengan CDC yang menggunakan tingkat perubahan udara per jam $(\mathrm{ACH})$, meskipun sebenarnya perhitungan $\mathrm{ACH}$ (tingkat perubahan udara) tersebut lebih sering digunakan secara umum sebagai pedoman. Penggunaan tingkat ventilasi (L/detik/pasien) lebih dapat mengidentifikasi hubungan langsung antara tingkat paparan dan tingkat aliran ventilasi udara yang dibutuhkan, sehingga rancangan perhitungan jumlah pasien yang dapat ditampung dalam ruangan tersebut dapat dikalkulasikan. 
CDC merekomendasikan $12 \mathrm{ACH}$ untuk pencegahan infeksi pada ruang tindakan yang menimbulkan aerosol, yang setara dengan, $160 \mathrm{~L} / \mathrm{dt} /$ pasien di ruang $4 \times 2 \times 3 \mathrm{~m}^{3}$. Pedoman ini merekomendasikan untuk melipatgandakan tingkat aliran ventilasi udara untuk pencegahan ruang tindakan yang menimbulkan aerosol dengan menggunakan ventilasi alami. Oleh karena itu, direkomendasikan untuk ruangan dengan volume yang sama (ruang praktik dokter gigi $4 \times 3 \mathrm{~m}$ ), maka harus mempunyai tingkat aliran ventilasi udara ratarata per jam $12 \mathrm{ACH}: 160 \mathrm{~L} / \mathrm{dt} /$ pasien dan atau tingkat aliran ventilasi udara minimum $160 \mathrm{~L} / \mathrm{dt} /$ pasien setiap saat.

Pengaturan aliran udara bersih dan kotor (terkontaminasi) perlu di identifikasi dan dibuat alur baru agar udara bersih dapat mengalir baik masuk ke dalam ruangan sampai dapat menuju keluar dengan arah yang berbeda dengan arah masuk udara bersih. Bagi dokter gigi yang menggunakan air conditioner (AC) maka harus memastikan adanya perputaran aliran udara. Penggunaan AC dengan konsep bukan mengalirkan air bersih dari luar atau tipe sirkulasi, yaitu mengambil udara bekas (udara yang disedot kembali dari dalam ruangan) sebagai supply udara, sehingga tidak ada pergantian udara yang terjadi sangat tidak direkomendasikan di ruang tindakan praktik dokter gigi. Tipe AC split wall, floor standing atau cassete, merupakan tipe yang sebaiknya tidak dipergunakan dalam ruang tindakan praktik dokter gigi. Tipe AC ini bisa digunakan pada zona non infeksius namun tetap wajib mengatur aliran udara di dalam ruangan agar tetap ada sirkulasi yang baik maka untuk itu dokter gigi diwajibkan mengidentifikasi aliran ventilasi dan air conditioning sistem (heating, ventilation, and air conditioning/HVAC). Sangat diperlukan konsultasi pada ahli nya untuk menentukan perputaran aliran udara dalam ruangan terjamin proses aliran ventilasi dari udara bersih dan keluar yang kemungkinan sudah terkontaminasi.

Pertukaran udara harus bisa terukur dengan baik untuk dapat memastikan proses pergantian untuk tindakan pasien berikutnya. Pengukuran pertukaran udara bersih dapat dipelajari dengan mengukur air changes hour $(\mathrm{ACH})$, yang ditetapkan lebih dari $12 \mathrm{ACH}$.

\section{B. Tata Kelola Ruangan}

Peralatan yang ada di dalam ruang praktik dokter gigi harus disimpan tertutup tidak boleh dibiarkan terbuka, usahakan semua tersimpan dalam laci atau lemari. Peralatan dan bahan medis yang akan dipergunakan dalam tindakan praktik yang dapat dikeluarkan dan dalam keadaan tertutup, hal ini untuk meminimalisir adanya kontaminasi silang yang mungkin terjadi. Kurangi kepadatan orang didalam ruang 
praktik dokter gigi, dengan meng gunakan skema four handed maka maksimal yang berada di dalam ruang praktik dokter gigi adalah 3 orang (dokter gigi, asisten dan pasien).

Ventilasi udara dan manajemen kualitas udara di klinik gigi dapat menjadi pedoman praktik dokter gigi sebagai berikut:

1) Pembagian zonasi kuning yaitu ruang receptionist/front office, ruang tunggu pasien, dan ruang staf. Zona merah adalah ruang yang dipergunakan untuk praktik (menghasilkan aerosol), dan dekontaminasi (doffing-melepas APD). Penggunaan APD merujuk ke bab 3.

2) Arah alur pergerakan pasien dan pergerakan tenaga medis harus teridentifikasi jelas, diatur dengan sign/tanda khusus yang dapat dipahami dengan baik. Alur pergerakan pasien dari mulai masuk fasilitas pelayanan kesehatan harus di atur agar selalu menjaga jarak dan kepadatan. Alur pergerakan tenaga medis baik dokter gigi, dan asisten yang beraktifitas di dalam ruang praktik harus dibuat khusus dan terdapat jalur ke ruang ganti atau dekontaminasi yang dibuat tidak bertemu dengan petugas atau ruang tunggu pasien secara langsung. Pertahankan sirkulasi udara dengan menggunakan udara alami melalui jendela yang sering dibuka dan gunakan exhaust blower independen untuk mengekstraksi udara ruangan keluar ruang bertemu udara terbuka sehingga terjadi dilusi.

3) Hindari penggunaan kipas angin atau AC yang diletakkan di langit-langit atau depan dental unit/kursi gigi yang arah anginnya mengarah dari pasien ke operator saat melakukan prosedur.

4) Sistem ventilasi yang memberikan pergerakan udara dari arah aliran yang bersih (area kerja atau area tim tenaga kesehatan gigi) ke yang terkontaminasi (area perawatan pasien klinis) harus dipasang dan dirawat dengan baik.

5) Letakkan kipas angin atau tipe AC yang tepat dengan posisi di belakang operator dan biarkan aliran udara menuju pasien. Kipas dengan aliran yang kuat ditempatkan sedemikian rupa untuk menciptakan aliran udara dari belakang operator dan menjauh posisi baik operator ataupun asisten.

6) Apabila menggunakan AC pastikan gunakan AC yang menggunakan aliran udara dari luar. Apabila yang digunakan ternyata AC split maka diperlukan pemasangan filter dan dipastikan tidak menyedot angin dari dalam ruangan. AC harus sering diservis, dan filter dibersihkan.

7) Arah aliran udara sejajar dengan petugas dari bersih ke kotor dengan mengatur letak posisi outlet udara masuk dan outlet (exhauster) udara kotor keluar, berfungsi mengarahkan atau menolak aerosol mengenai langsung ke petugas. 
8) Posisi dental unit juga diatur dengan posisi kepala pasien berada pada arah masuk aliran udara bersih, yang terletak di belakang dokter gigi ke arah pasien dan dihisap dengan exhauster yang diletakkan $20 \mathrm{~cm}$ dari lantai sebagai penghisap aliran udara kotor.

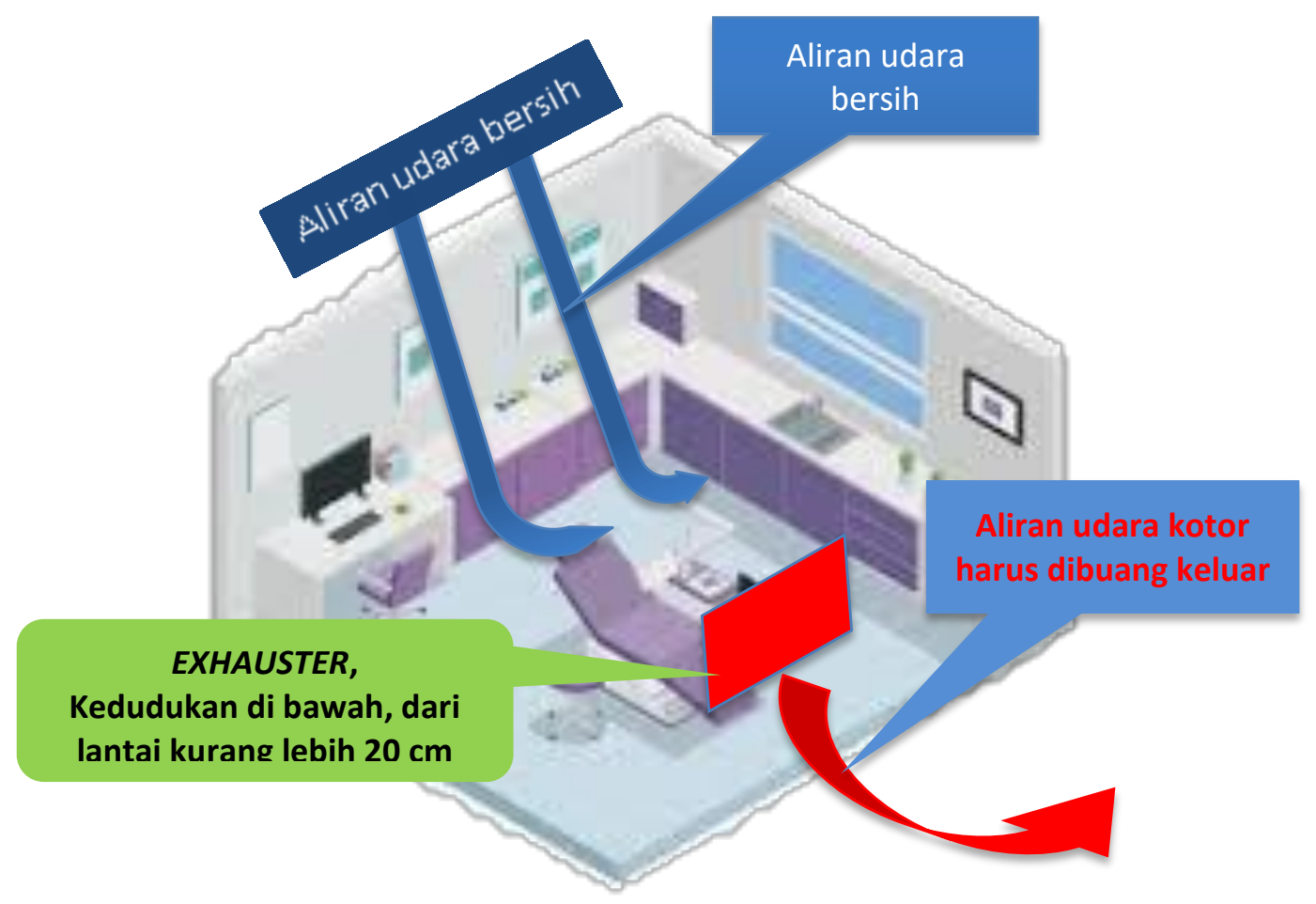

Gambar 6. Simulasi arah aliran udara dalam ruang praktik dokter gigi.

9) Penggunaan sistem pembersihan udara portabel dalam ruangan yang dilengkapi dengan filter HEPA dan sinar UV, sangat dianjurkan untuk dapat digunakan namun perlu diperhatikan bahwa pembiayaan yang diperlukan cukup mahal. Apabila bekerja pada gedung dengan menggunakan pola AC terpusat (centralized), maka harus dipastikan sirkulasi udara mengambil udara bersih dari luar (bukan dari dalam ruang praktik). Hal ini sering dijumpai ada ruangan yang menggunakan AC sentral. Ketentuan yang wajib di ikuti adalah biarkan udara segar/bersih masuk ke ruang praktik dokter gigi dan dikeluarkan menggunakan exhauster bertekanan kuat agar tercipta sirkulasi udara bersih dan kotor yang tepat. Penempatan exhauster yang baik adalah diletakkan di bawah, kurang lebih dari lantai $20 \mathrm{~cm}$. Exhauster yang diletakkan di langit-langit ruangan akan menimbulkan udara berputar dan tidak terbentuk sirkulasi udara yang baik. Udara yang dibuang melalui exhauster harus langsung terhubung dengan udara luar gedung/ruang praktik dokter gigi.

10) Penggunaan high volume evacuator (HVE) adalah mesin evacuator volume 
tinggi dengan kemampuan hisap besar selama periode waktu tertentu dandipasang pada sistem evakuasi yang dapat menghilangkan volume udara lebih besar dari 100 kaki kubik per menit (cfm). HVE dapat mengatasi pengurangan aerosol tetapi teknis dan spesifikasi harus dipertimbangkan oleh dokter gigi dalam menggunakan HVE.

11) Suction dental unit mempunyai saluran pembuangan menyatu dengan pembuangan dental unit. Penggunaan suction dental unit sebagai HVE harus digunakan saat praktik pada pasien yang menghasilkan aerosol. Kekuatan vakum harus lebih dari $100 \mathrm{cfm}$ menjadi syarat wajib yang harus terpenuhi dan di tera ukur ulang sebulan sekali.

12) Penggunaan HVE portable harus memastikan HEPA filter yang digunakan serta proses pembuangan air keluar produk HVE tersebut. Pastikan udara yang keluar sudah melalui tahap pemusnahan virus SARS-CoV-2 dan atau pastikan ada saluran pembuangan langsung ke lingkungan luar yang terbuka sehingga terjadi proses dilusi.

13) Penggunaan unit-unit HEPA filter portabel juga akan mengurangi jumlah partikel (termasuk droplet) di dalam ruangan dan akan mengurangi jumlah waktu pertukaran udara, daripada hanya mengandalkan kapasitas aliran udara di dalam gedung (sistem HVAC). Namun penggunaan unit HEPA filter memerlukan pembiayaan yang cukup tinggi.

14) Apabila menggunakan unit HEPA portable tempatkan di sekitar kursi pasien, tetapi tidak di belakang tenaga kesehatan gigi yang sedang melakukan tindakan kepada pasien. Pastikan dokter gigi dan asisten tidak berada di antara unit dan mulut pasien. Posisikan unit HEPA portable tidak menarik udara ke dalam atau melewati zona pernafasan tenaga kesehatan gigi.

Tabel 3. Spesifikasi high volume evacuator.

\begin{tabular}{|l|c|c|}
\hline \multicolumn{1}{|c|}{ Keterangan } & Diluar dental unit & Menyatu dental unit \\
\hline Voltage & $220 / 50 \mathrm{~Hz}$ & $220 / 50 \mathrm{~Hz}$ \\
\hline Power & $500-1000 \mathrm{KW}$ & $250-500 \mathrm{KW}$ \\
\hline Kekuatan vakum & $10-35 \mathrm{Kpa}$ & $10-35 \mathrm{Kpa}$ \\
\hline Kekuatan aliran udara minimal & $3000 \mathrm{Itr} / \mathrm{menit}$ & lebih besar dari $100 \mathrm{cfm}$ \\
\hline HEPA Grade & 13 & $\mathrm{NA}$ \\
\hline HEPA Filter efisiensi & $99.9 \%$ & $\mathrm{NA}$ \\
\hline HEPA Filter element's use life & $6-12$ bulan & $\mathrm{NA}$ \\
\hline Kebisingan & kurang dari 65 & kurang dari 65 \\
\hline Diameter pipa suction $(\mathrm{mm})$ & $40-60$ & $25-50$ \\
\hline Panjang pipa suction/arm length $(\mathrm{cm})$ & $150-200$ & $150-200$ \\
\hline
\end{tabular}


15) Dokter gigi perlu memeriksa kekuatan dan volume aliran udara HVE secara berkala, karena ada HVE dengan sistem yang memiliki aliran udara bersih dan menunjukkan aliran udara yang cukup tetapi ternyata dalam pengukuran statis tekanan vakum $(\mathrm{mmHg}$ ) tekanan yang ada sangat rendah. HVE dengan pola sistem seperti ini, akan menghasilkan arus balik yang tidak diharapkan.

16) Jarak yang tepat harus dijaga oleh dokter gigi saat memegang perangkat HVE. Perangkat harus dipegang dengan jarak sekitar $6-15 \mathrm{~cm}$ dari ujung aktif atau polisher udaranya. Saat menggunakan HVE, dokter gigi perlu mencari posisi saat mengakses mulut dengan nyaman. Sudut kemiringan (angulasi) dari perangkat HVE ke mulut pasien harus dilakukan untuk menghindari kontak dengan pipi/lidah pasien. Ada keterbatasan gerakan yang ergonomis bagi dokter gigi dan mungkin akan menghadapi kesulitan dalam memegang HVE yang berat; atau akan mengakibatkan akses visibilitas penglihatan langsung menjadi terhalang. Untuk mengatasi permasalahan ini dapat menggunakan HVE Mirror system yang di design oleh Nu-Bird (Gambar 7).
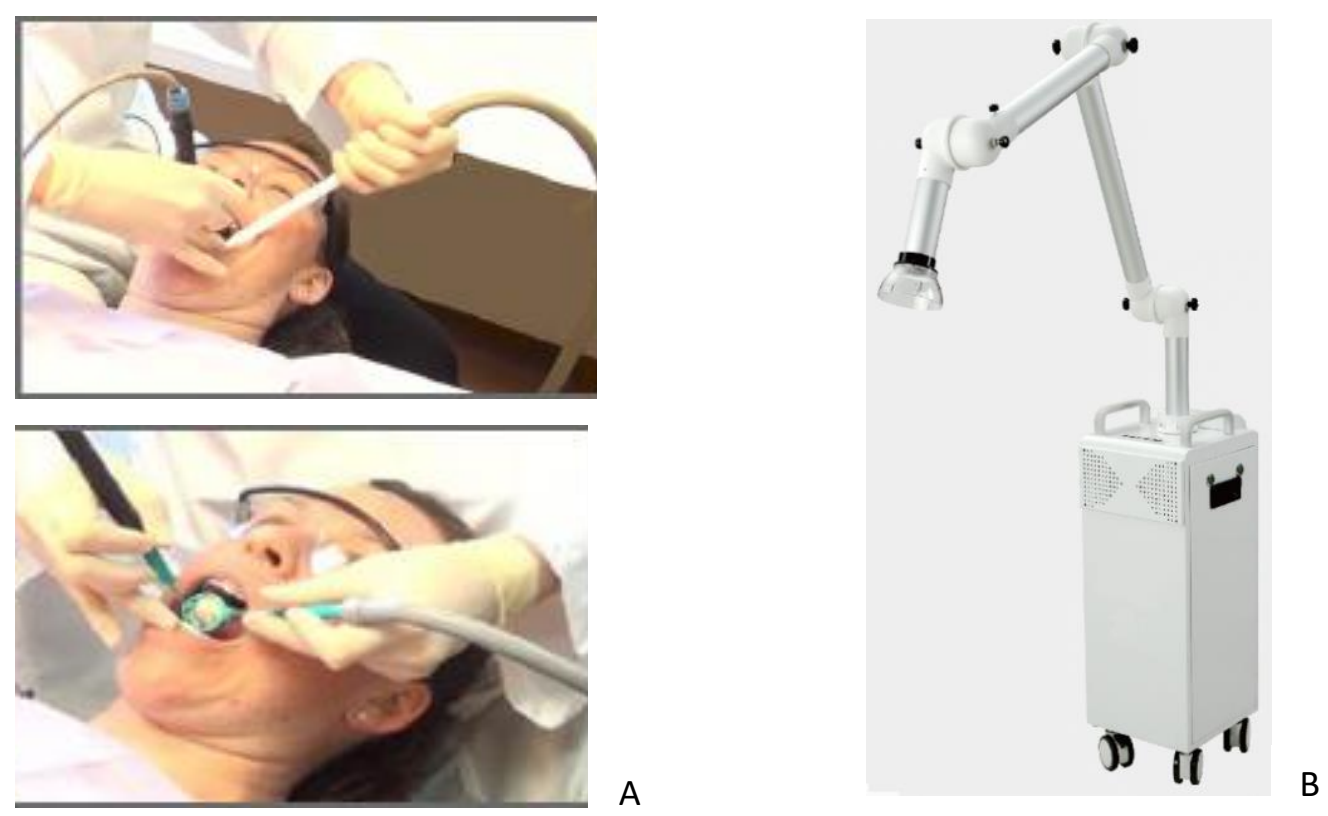

Gambar 7. A. High volume evacuator yang terpasang langsung di dental unit.

B. High volume evacuator yang diluar dental unit.

17) Pertimbangkan penggunaan iradiasi ultraviolet (UV) pada ruang praktik sebagai tambahan untuk pembersihan udara yang lebih tinggi. Penggunaan lampu UV merujuk ke bab 4. 


\section{Exhaust Fan}

Cara menghitung kapasitas kipas angin untuk aliran udara dalam ruang praktik. Rumus kekuatan exhaust fan = volume ruang (dalam feet) $\times 12$ ach (rekomendasi CDC) Misalkan ruang $4 \mathrm{~m} \times 3 \mathrm{~m}$ dengan tinggi (dari lantai ke atap langit-langit) $2 \mathrm{~m}$.

Maka perhitungannya adalah:

Volume ruangan $4 \times 3 \times 2=24 \mathrm{~m}^{3}$

$$
24 \mathrm{~m} 3 \times 12 \mathrm{ach}=288 \mathrm{~m}^{3} / \mathrm{h}
$$

Konversikan ke cfm (Cubic feet/menit)

1 jam $=60$ menit,

$1 \mathrm{~m} 3=35.31 \mathrm{ft}^{3}$,

Jadi $1 \mathrm{~m} 3 /$ hour $=35.31 / 60=0.58 \mathrm{ft}^{3} /$ menit,

sehingga $288 \mathrm{CMH}=288 \times 0.58=167 \mathrm{CFM}$

kekuatan exhauster fan yang harus dicari adalah $167 \mathrm{cfm}$.

Untuk memudahkan perhitungan cfm, dapat menggunakan tautan

berikut https://www.convertunits.com/from/cubictm/hr/to/cfm

\section{Ruang Ganti APD}

Desain ruang untuk praktik dokter gigi atau klinik wajib mengalokasikan ruang yang dipergunakan untuk ganti baju. Ruang ganti tersebut harus tersedia bagi dokter gigi, staf dan semua pekerja untuk mengganti baju untuk bekerja di dalam praktik dokter gigi sesuai rekomendasi. Suatu area khusus harus dibuat untuk memakai dan melepas APD/PPE. Ruangan ganti baju APD (donning PPE) dan ruang untuk melepas APD (doffing PPE) sebaiknya dibedakan. Di dalam ruang untuk melepas APD (doffing PPE) wajib diberi fasilitas untuk cuci tangan (hand hygiene) dan pengelolaan limbah. Pastikan di dalam kedua ruangan aliran ventilasi udara mempunyai sirkulasi sesuai petunjuk diatas. Tata letak ruang ganti atau ruang melepas APD dibuat alur sebagai zona merah dan tidak bertemu dengan pasien atau staff pendukung yang mobilitasnya ada di zona kuning atau hijau. 


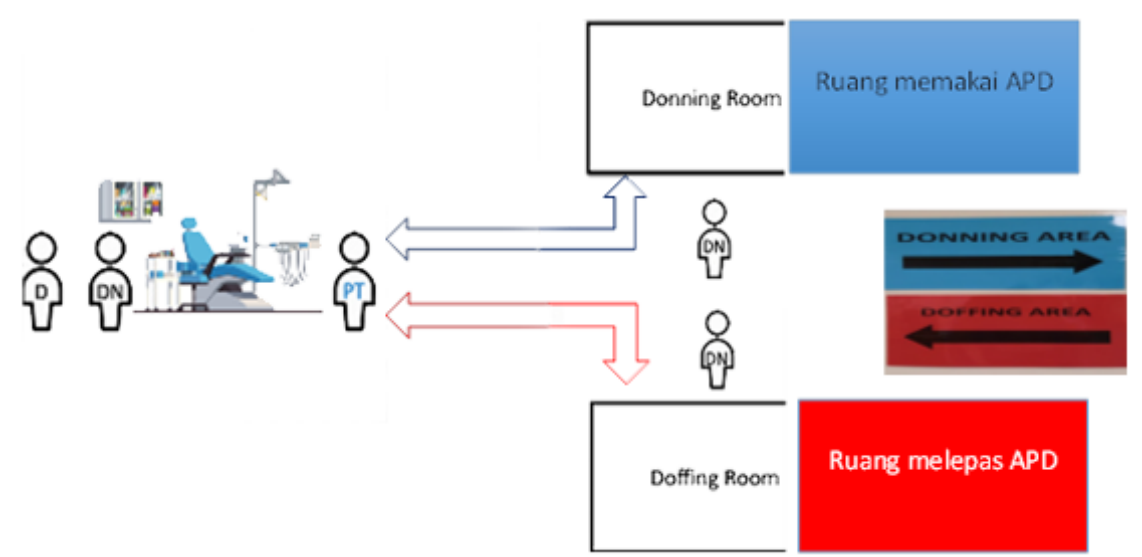

Gambar 8. Pemisahan ruang antara ruang praktik dental unit, ruang donning dan doffing APD. Signage ruang donning dan doffing perlu dilekatkan di dinding untuk mengingatkan kewaspadaan APD.

Ruang donning dan doffing wajib berbeda dan di dalam setiap ruangan wajib ditempelkan tahapan donning dan doffing.

\section{Ruang pemakaian (donning) APD}

1) Pemakaian APD harus dilakukan sebelum tenaga kesehatan memasuki ruang tindakan praktik dokter gigi, sehingga tata letak diatur dengan alur khusus.

2) Ruang pemakaian APD wajib ada gambar tahapan donning APD (Gambar 22).

3) Penyediaan bahan disinfektan menggunakan hand sanitizer berbahan dasar alkohol $70 \%$ yang dipasang/dipaku di dinding.

4) Penyediaan sarung tangan, masker bedah disediakan di ruang pemakaian donning.

5) Pemasangan cermin untuk membantu operator/petugas kesehatan saat memakai APD.

6) Apabila diperlukan di dalam ruangan pemakaian APD (donning) terdapat loker atau lemari untuk menyimpan baju pakaian tenaga kesehatan (baju dari rumah) yang disimpan dalam plastik atau hanger yang digantung di dalam lemari atau loker tertutup.

7) Perlengkapan APD lengkap (baju, gown all cover, head cover, shoe cover dan lain-lain) sudah disiapkan dalam packing bertanda steril (yang menandakan bahwa bahan APD telah dilakukan disinfeksi)

8) Goggle, facemask diberi label berisi nama tenaga medis, tanggal pemakaian dan berapa kali sudah dipakai. Pemakaian ulang goggle dan facemask harus dipastikan di dalam wadah steril (kontainer plastik) dan ditandai telah dilakukan disinfeksi pada tanggal berapa dan diberi paraf petugas yang melakukan disinfeksi. 
9) Apabila menggunakan sepatu boot, disediakan tempat sepatu untuk menempatkan sepatu dan diberi tanda label nama tenaga kesehatan, dan label telah di disinfeksi.

\section{Ruang melepas (doffing) APD}

1) Harus sesuai dengan pedoman untuk pencegahan dan pengendalian infeksi yang direkomendasikan.

2) Jika tidak ada kamar, CDC merekomendasikan melepas APD (doffing) dan sarung tangan di lakukan ruang tindakan pasien. Sedangkan untuk melepas pelindung wajah/goggle/face shield dan masker dilakukan di luar ruang tindakan pasien. Apabila APD sudah dilepas semua wajib melakukan kebersihan tangan dengan urutan yang benar.

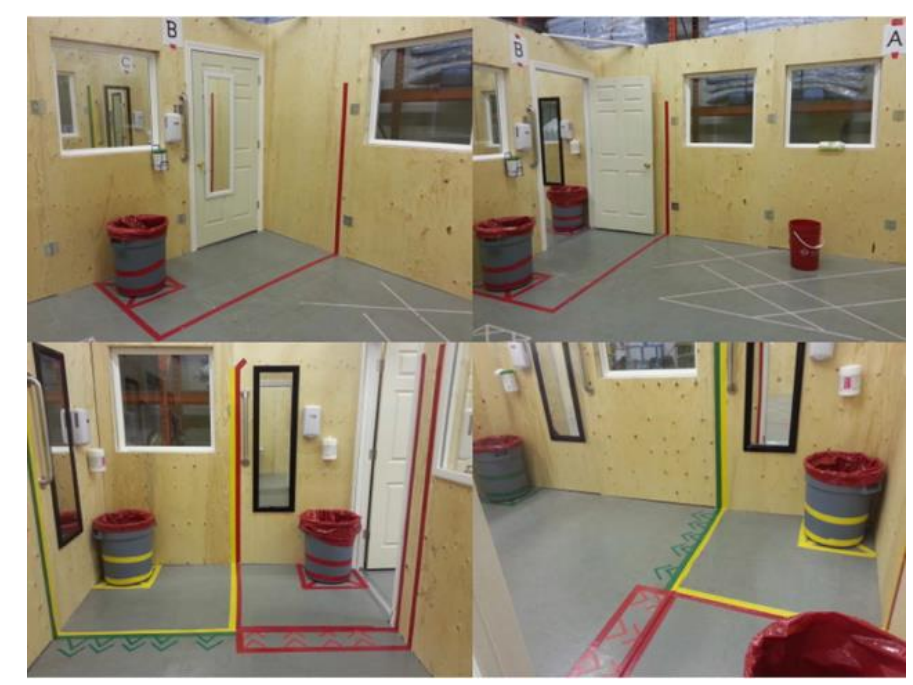

Gambar 9a. Pengaturan ruang pelepasan APD.

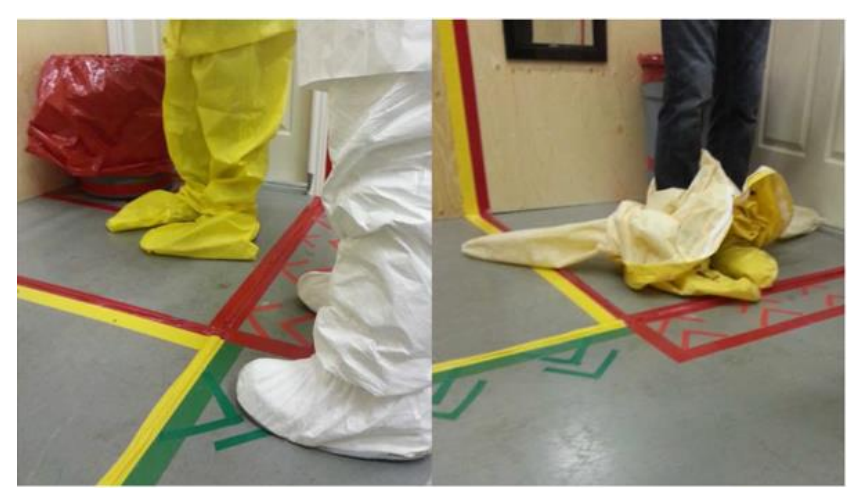

Gambar 9b. Demarkasi zona dapat mencegah operator (tetapi bukan sarana prasarana) menyeberang dari zona bersih ke zona "kotor". (Merah = "tata laksana infeksius", Kuning= "kehati-hatian", dan Hijau = "Jalur bersih"). 
Pengelolaan area doffing harus dilakukan penuh kehati-hatian tinggi untuk membatasi penyebaran kontaminasi. Pengaturan harus dilakukan menggunakan tanda stiker untuk membagi ruang menjadi zona yang lebih kecil yang berfungsi untuk membatasi pergerakan petugas kesehatan selama proses doffing. Zona yang lebih kecil ini berhasil membatasi pergerakan petugas kesehatan, dan kontaminasi tidak menyebar di luar zona kotor.

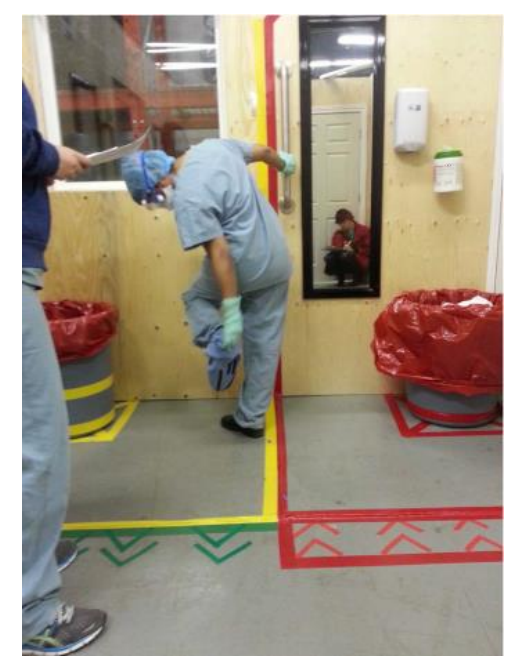

Gambar 10. Pegangan tangan saat doffing APD.

Sarana yang wajib dilengkapi dalam ruang doffing

1) Penyediaan bahan disinfektan menggunakan hand sanitizer berbahan dasar alkohol 70\% yang dipasang/dipaku di dinding.

2) Pemasangan gambar tahapan doffing APD (Gambar 23).

3) Penempatan semua alat bantu doffing harus dipertimbangkan dengan cermat untuk meminimalkan kontak dengan peralatan dan untuk memastikan aliran yang benar selama proses doffing.

4) Ruang doffing sebaiknya tidak ada perabot atau furniture, sehingga seperti ruang terbuka. Pembersihkan ruang lantai (disinfeksi) sangat diperlukan untuk mencegah kontaminasi silang. Oleh sebab itu dengan mengurangi jumlah perabotan di area doffing (misalnya lemari dan kursi dan lain-lain), membuat area doffing lebih mudah di lakukan disinfeksi berkala. Pastikan peralatan tetap berada di lokasi yang sama (misalnya pembersih tangan, tisu desinfektan, dan cermin), agar alur urutan doffing tetap terkontrol.

5) Tandai area perbedaan zona dengan menggunakan stiker berbeda warna berupa garis memanjang ke atas dinding yang mudah terlihat, berguna untuk membantu meningkatkan kewaspadaan dalam mencegah kontaminasi. 
6) Selama doffing, diperlukan cermin untuk membantu operator/petugas kesehatan saat melepas APD. Sebagai contoh ketika petugas kesehatan akan melepas ritsleting coverall baju di bawah dagu, maka cermin dapat membantu menunjukkan tingkat kekotoran APD sebelum doffing, sehingga petugas dapat lebih berhati hati.

7) Pegangan tangan ditempatkan pada dinding agar menghemat ruang, dan terbuat dari bahan yang mudah dibersihkan/disinfeksi. Pegangan tangan ini sangat diperlukan untuk menjaga keseimbangan yang cukup saat melepas APD, khususnya ketika membuka (doffing) menutup sepatu/alas kaki.

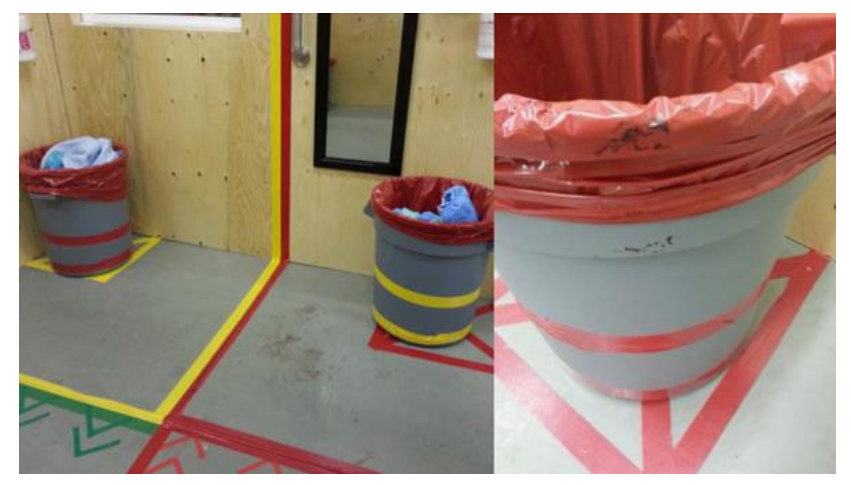

Gambar 11. Tanda demarkasi pembagian lokasi doffing.

8) Ukuran kontainer tempat pembuangan yang akan digunakan sebagai tempat pembuangan diatur dengan beberapa ukuran yang berbeda di setiap zona yang di telah ditetapkan (warna kuning dan warna merah), hal ini perlu disesuaikan dengan jumlah APD yang akan dilepas di zona tersebut. Kontainer pembuangan baju APD berukuran lebih besar, dapat ditempatkan di zona merah. Untuk baju APD yang digunakan kembali, dapat dimasukkan ke dalam kontainer yang berisi air detergen dan direndam selama 10 menit. Alasan mendasar untuk mengatur ukuran kontainer pembuangan adalah karena pembuangan baju APD cenderung terisi dengan cepat. Sehingga sangat penting untuk menerapkan prosedur pembuangan yang efektif di tempat kontainer pembuangan dan agar dapat dipastikan bahwa sampah infeksius hasil APD tidak meluap melebihi kapasitas kontainer. Pengaturan ini perlu dilakukan agar saat melakukan pengangkatan sampah infeksius APD tidak dilakukan berkali-kali, sehingga meminimalkan risiko kontaminasi ke dan dari petugas cleaning yang akan melaksanakan tugasnya.

9) Kontaminasi dapat menyebar dari APD ke tempat pembuangan atau kontainer. Pergerakkan kontainer saat akan dilakukan pembuangan ini sangat memerlukan perhatian, karena dapat mengkontaminasi tenaga kesehatan. 
Oleh karena itu perlu diatur dengan stiker tanda serta nama kontainer pembuangan APD dan kontainer perendaman APD yang dapat digunakan kembali.

\section{E. Fasilitas Pendukung dan Ketentuan Lain}

Selain ruangan dan ventilasi udara, dalam praktik dokter gigi perlu melakukan beberapa fasilitas pendukung agar pengendalian infeksi COVID-19 dapat dilakukan dengan maksimal. Beberapa catatan alur pengelolaan praktik dokter gigi perlu lakukan adalah sebagai berikut:

1) Pada pintu masuk utama pastikan ditempel signage (tanda khusus) atau di tempel pada strategis seperti ruang tunggu yang mudah dibaca pasien tentang: tentang kebersihan pernapasan, penggunaan masker, etiket batuk, jarak yang harus dijaga (physical distancing), dan pembuangan limbah yang terkontaminasi dalam sampah infeksius.

2) Pasang penghalang kaca, plastik atau fiber pada meja bagian penerima tamu (recepsionist/front office). Pastikan ketersediaan masker dan hand sanitizer yang cukup dan tisu kertas di meja pendaftaran, serta tempat sampah infeksius.
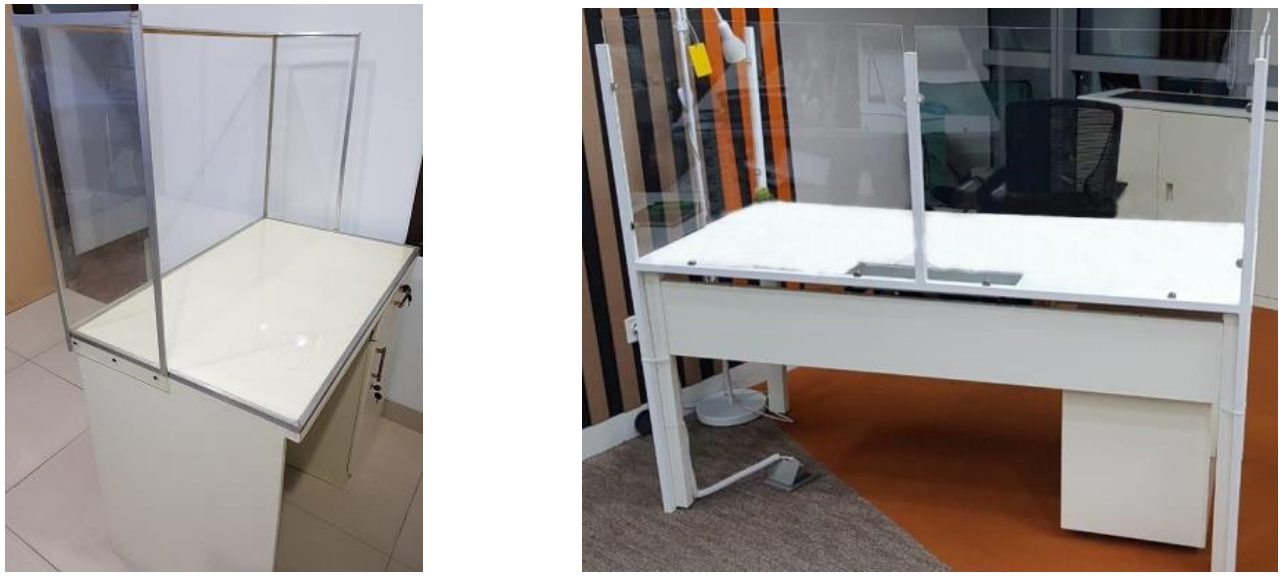

Gambar 12. Separator wall (dinding penghalang) yang terpasang di meja dokter gigi. 
3) Kursi tunggu ditata dengan letak yang sebaiknya terpisah satu meter antar pasien.

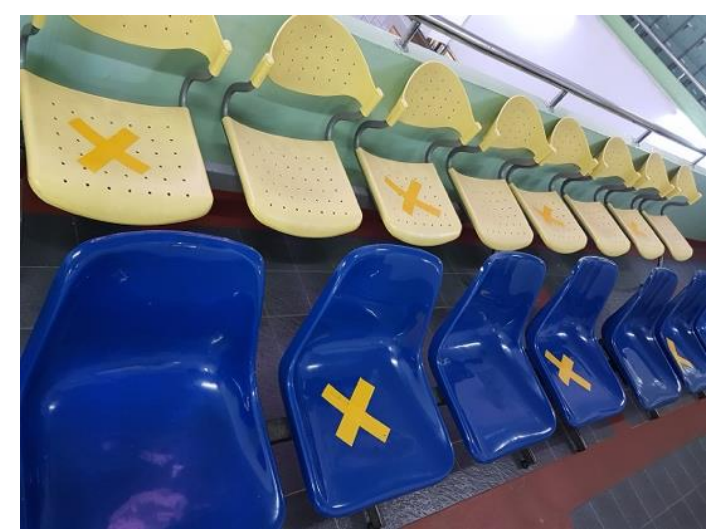

Gambar 13. Signage di kursi ruang tunggu agar pasien saling menjaga minimal 1 meter.

4) Semua area harus bebas dari semua konten seperti majalah, mainan anak, remote TV, atau artikel serupa.

5) Metode pembayaran diupayakan dengan menggunakan debit atau kartu kredit (cashless/contactless) lebih di prioritaskan.

6) Tempat sampah harus dengan penutup dan tersedia di triase mudah terlihat pasien agar dapat membuang benda-benda yang tidak dibutuhkan. Tempat sampah dalam ruang tunggu pasien tersedia 2 macam yaitu organik dan non organik, sedangkan tempat sampah di ruang dental unit tersedia 2 macam, yaitu infeksius dan non infeksius.
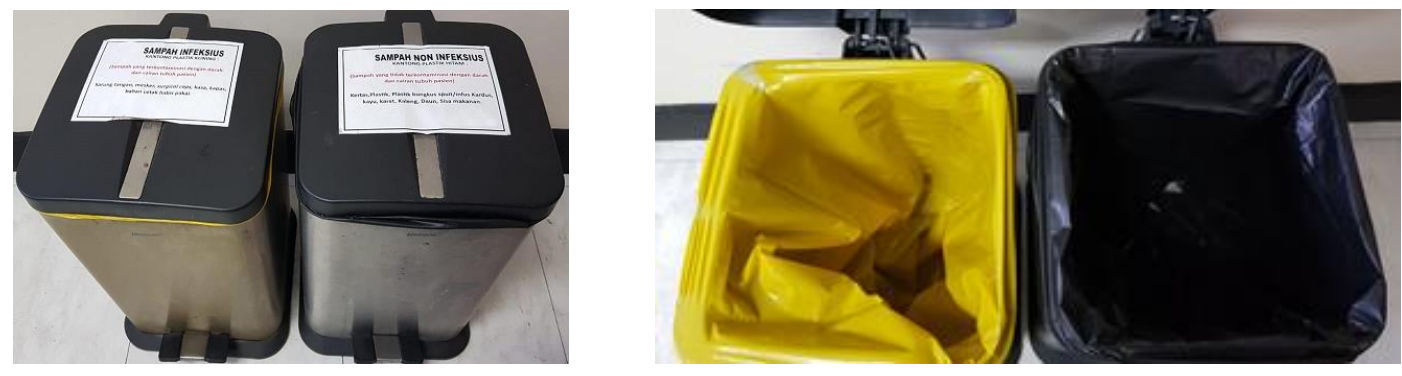

Gambar 14. Tempat sampah di ruang dental unit terdiri dari infeksius dan non infeksius. Tempat sampah infeksius dilapisi dengan kantong plastik warna kuning, sedangkan non infeksius dilapisi dengan kantong plastik warna selain kuning (contoh hitam). 
7) Ruang sterilisasi harus dioperasikan oleh tenaga yang terlatih untuk melakukan sterilisasi alat dengan tepat, transportasi alat, pembersihan alat, pengeringan alat, pengepakan alat, penyimpanan alat dilakukan dalam proses satu kesatuan sterilisasi sesuai dengan pedoman standar dan instruksi pabrik.

8) Harus dipastikan tersedia ruang yang memadai untuk penyimpanan instrumen steril, item APD tambahan dan bahan disinfektan.

9) Atur ruang praktik dokter gigi agar hanya persediaan dan instrumen yang bersih atau steril yang diperlukan untuk prosedur gigi yang mudah diakses. Semua persediaan dan instrumen lainnya harus berada dalam penyimpanan tertutup atau pack steril, di dalam laci atau lemari (lemari sterilisasi/box UV), dan jauh dari kemungkinan kontaminasi. Persediaan dan peralatan apa pun yang terpapar tetapi tidak digunakan selama prosedur harus dianggap terkontaminasi dan harus dibuang atau diproses ulang disinfeksinya setelah prosedur selesai.

10) Volume pasien, tentukan jumlah maksimum pasien yang dapat dikerjakan selama jadwal jam praktik. Hal ini dapat ditetapkan berdasarkan jumlah kamar praktik dokter gigi, luas ruang praktik dokter gigi, tata letak fasilitas prasarana yang digunakan di dalam ruangan, dan waktu yang diperlukan untuk membersihkan dan mendisinfeksi prasarana tersebut. Untuk memberikan waktu disinfeksi droplet yang terjadi setelah tindakan prosedur gigi, tim tenaga kesehatan gigi harus menunggu setidaknya 15 menit setelah selesainya perawatan gigi dan memulai pembersihan kamar dan proses disinfeksi sebelum memasukkan pasien baru.

11) Bila memungkinkan, hindari prosedur tindakan yang menghasilkan aerosol.

12) Jika prosedur yang menghasilkan aerosol diperlukan untuk perawatan gigi, gunakan konsep four handed dentistry (terdapat asisten yang membantu), yang dapat melaksanakan prosedur suction evakuasi tinggi dan penggunaan rubber dam/dental dum untuk meminimalkan percikan droplet dan aerosol.

13) Minimalisir jumlah tenaga kesehatan di dalam ruang praktik dokter gigi selama prosedur tindakan dilakukan. Hanya operator (dokter gigi), asisten dan pasien yang ada di dalam ruang praktik. Penunggu pasien dewasa disarankan untuk tidak masuk dalam ruang praktik dokter gigi. 


\section{F. Alat Kedokteran Gigi Tambahan}

Dalam melakukan tindakan preparasi kavitas gigi, dokter gigi memerlukan isolasi daerah kerja. Tujuan dari isolasi ini adalah

1) Mencegah masuknya cairan sulkus gingiva, saliva dan darah.

2) Retraksi jaringan lunak sehingga pandangan secara klinis menjadi lebih jelas.

3) Mencegah terjadinya kecelakaan (trauma mekanik) selama prosedur kerja.

4) Proteksi operator

5) Efisiensi kerja.

Beberapa jenis alat isolasi daerah kerja yang telah dikenal antara lain high volume evacuator, saliva ejector, absorbent, pelindung kerongkongan, alat bantu (benang retraksi, kaca mulut pengganjal mulut) dan rubber dam (isolator karet). Penggunaan rubber dam ini telah disarankan oleh CDC untuk mencegah transmisi partikel virus yang terkandung dalam aerosol saat dilakukan preparasi dengan handpiece. Menurut Cochran dkk (1989), efektivitas rubber dam dalam mencegah penularan mikroorganisme sebesar 95-99\%. Namun, penggunaan rubber dam juga memiliki kontra indikasi yaitu:

1) Gigi dengan restorasi mahkota porselen

2) Gigi belum erupsi sempurna

3) Pasien asma

4) Pasien penyakit Parkinson

5) Alergi terhadap karet (rubber)
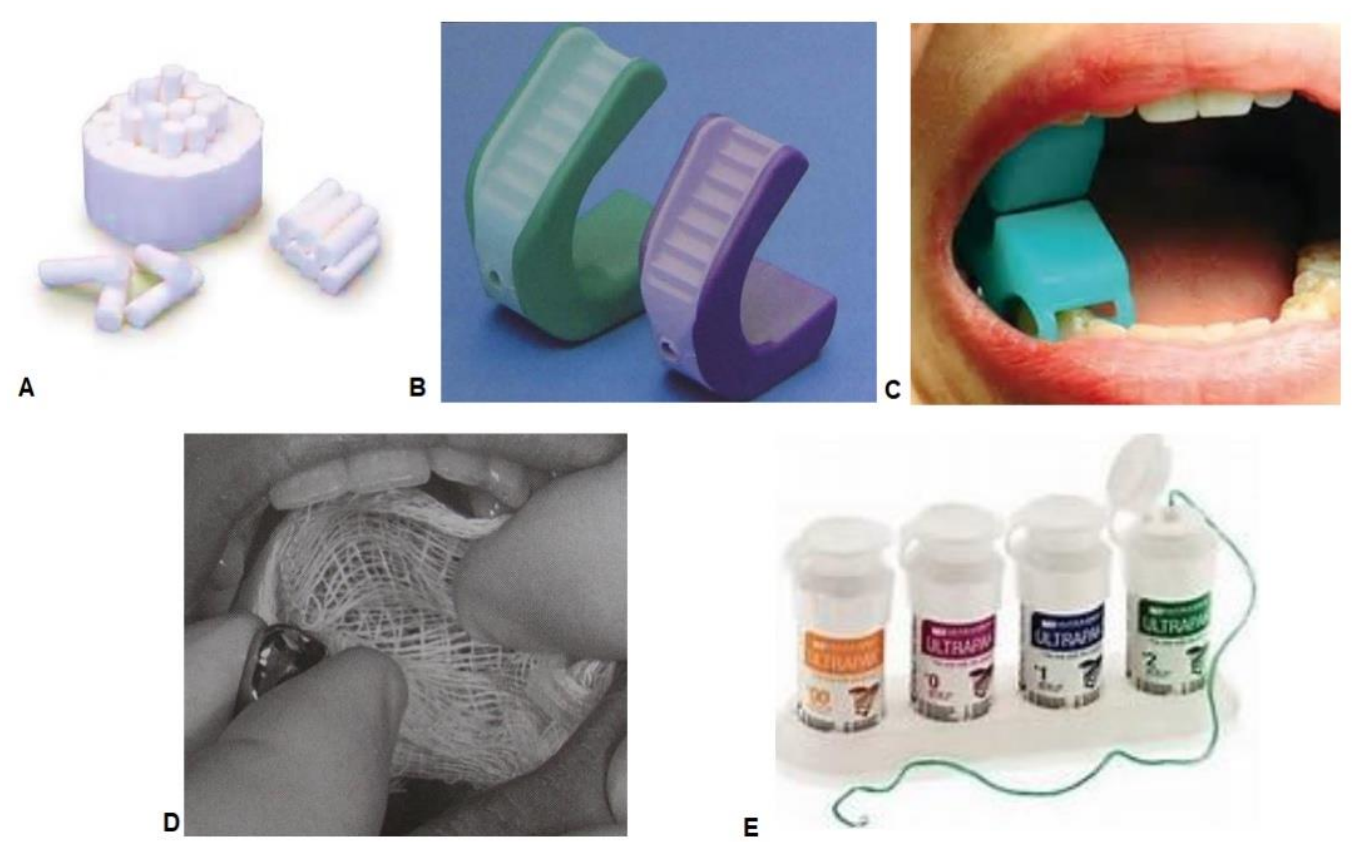

Gambar 15. A. Absorbent. B. dan C. Mouth prop. D. Throat shield. E. Benang retraksi. 
Untuk dapat melakukan pemasangan rubber dam yang sempurna, diperlukan beberapa alat kedokteran gigi yaitu:

1) Rubber dam
a) Rubber dam sheet
b) Rubber dam frame
c) Rubber dam clamp
d) Rubber dam punch
e) Rubber dam forceps

2) Instrument

a) Plastic filling instrument

b) Burnisher

c) Dental floss

d) Saliva ejector

e) Tisu kertas (opsional)

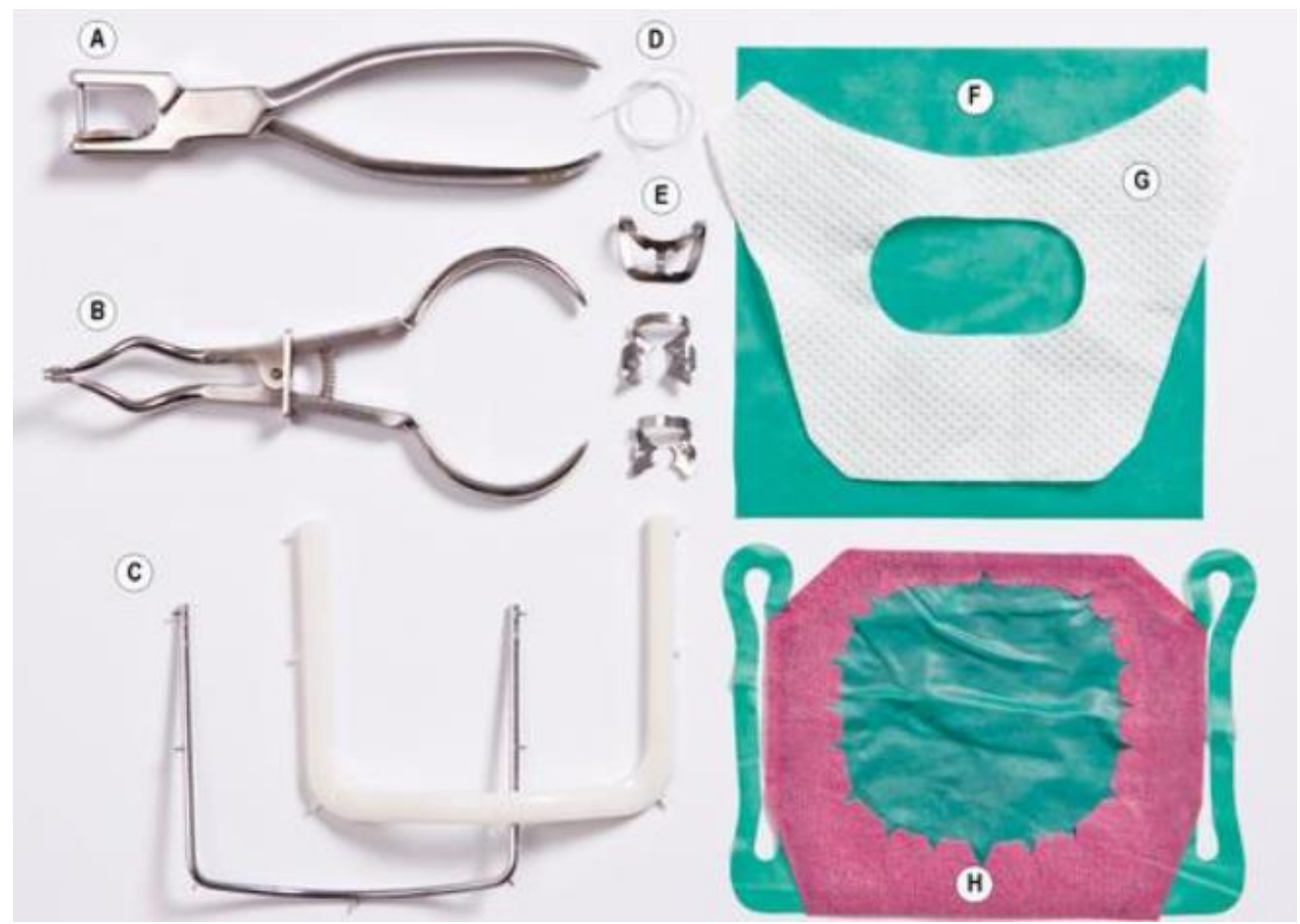

Gambar 16. A. Rubber dam punch. B. Rubber dam forceps. C. Rubber dam frame. D. Dental floss. E. Rubber dam clamp. F. Rubber dam sheet. G. Tisu kertas (diletakkan antara kulit dan rubber dam sheet, sehingga dapat menyerap saliva jika ada kebocoran saliva dari rubber dam). H. Rubber dam sheet yang menyatu dengan napkin dan frame. 
Tehnik pemasangan rubber dam dapat dibagi menjadi beberapa jenis, yaitu:

(Walton dan Torabinejad, 2002)

1) Teknik pemasangan clamp sebelum pemasangan rubber dam

- Clamp dipasang terlebih dahulu pada gigi, sehingga tepi gingiva dan gigi lebih jelas selama pemasangan.

- Clamp yang dianjurkan adalah clamp dengan kekuatan retentif yang besar yaitu bersayap atau tidak bersayap dengan jaws yang tajam.

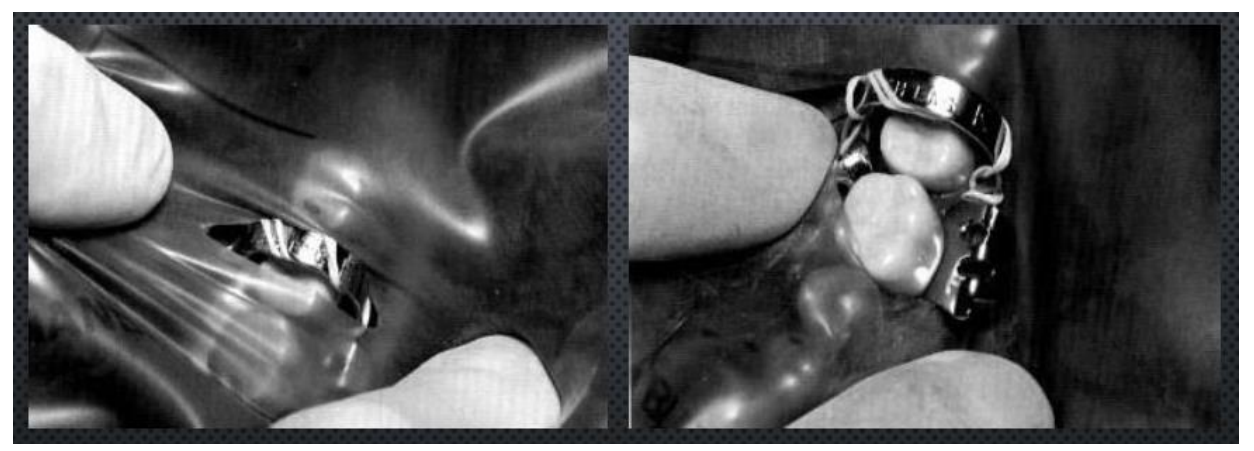

Gambar 17. Teknik pemasangan clamp sebelum pemasangan rubber dam.

2) Teknik pemasangan clamp bersamaan dengan rubber dam

- Clamp bersayap yang dicobakan terlebih dahulu

- Pandangan ke arah gigi dan ke tepi gingiva menjadi terbatas

- Direkomendasikan untuk molar ketiga dimana teknik lain akan sulit dilakukan

- Penglihatan operator terhadap seluruh gigi menjadi terbatas

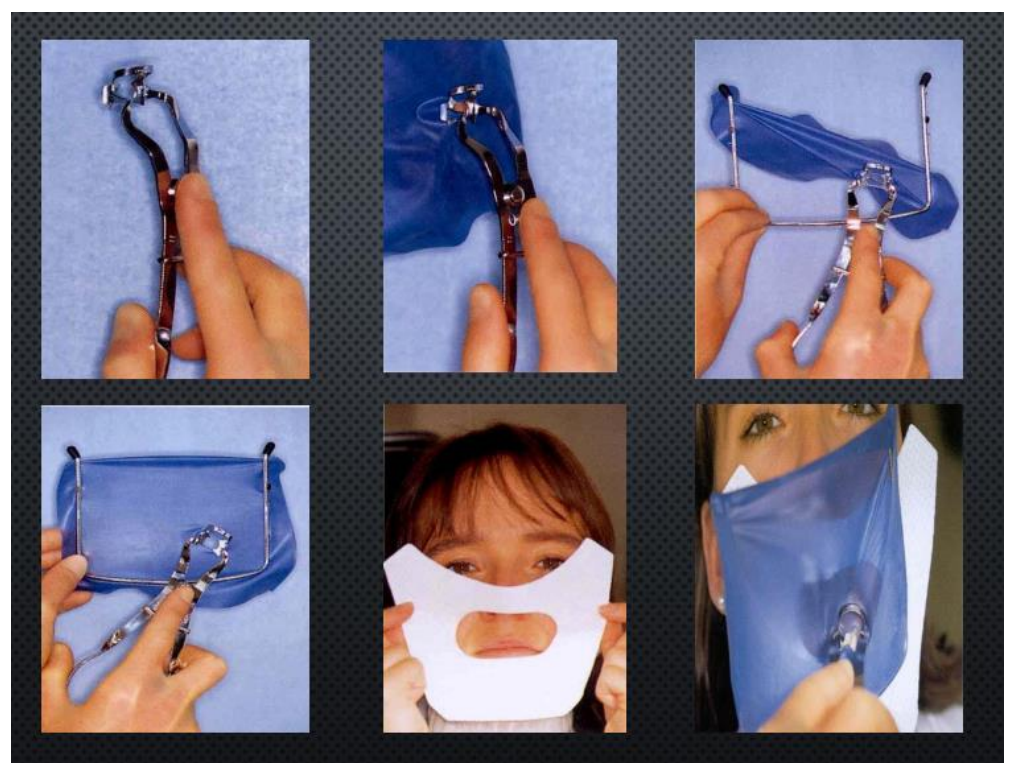

Gambar 18. Teknik pemasangan clamp bersamaan dengan rubber dam. 
3) Teknik pemasangan clamp setelah pemasangan rubber dam

- Sulit bila operator bekerja sendiri.

- $\quad$ Teknik dipakai bila clamp yang digunakan berukuran besar sehingga lubang yang dibuat akan menjadi sangat besar, menyebabkan kemampuan isolasi berkurang.

- Clamp yang diperlukan untuk teknik ini adalah jenis butterfly clamp.

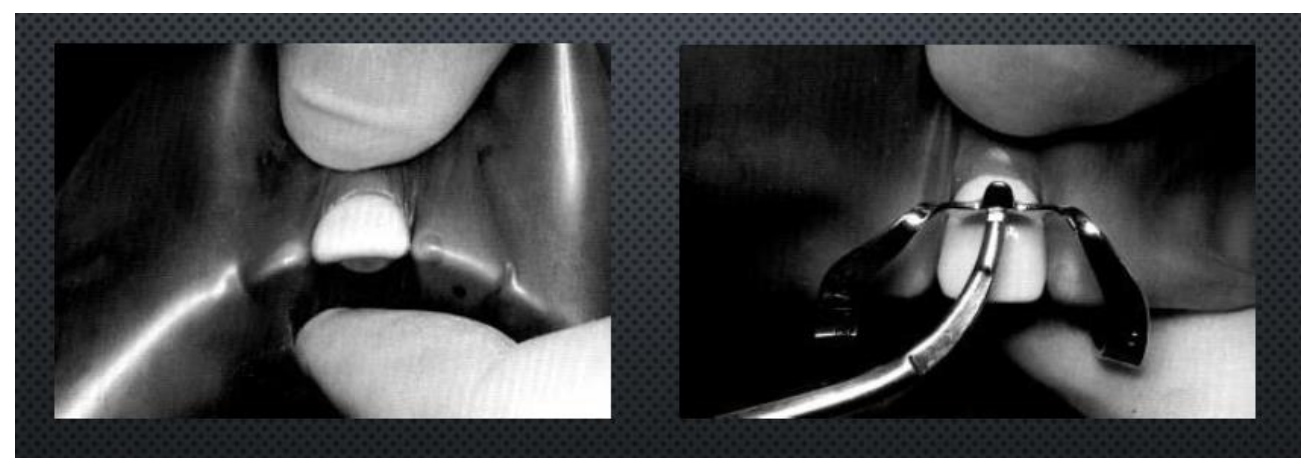

Gambar 19. Teknik pemasangan clamp setelah pemasangan rubber dam.

4) Teknik split dam

- Jika dilakukan pada gigi anterior, tidak menggunakan clamp.

- Keuntungannya dapat dilakukan pada gigi dengan kehilangan struktur yang luas, adanya fraktur horisontal dan mencegah pecahnya tepi restorasi porselen.

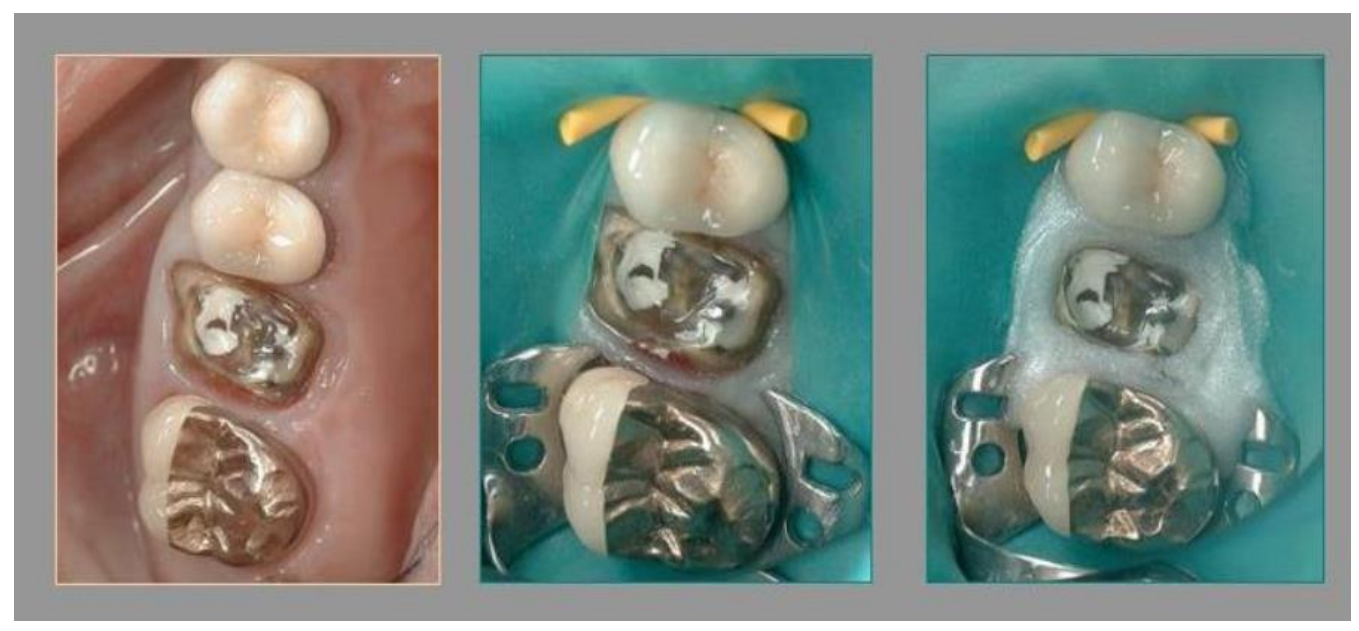

Gambar 20. Teknik split dam. 


\section{5) Teknik bow}

- Clamp yang digunakan jenis wingless.

- Dapat digunakan pada gigi belakang.

- Bow clamp dikaitkan dahulu dengan rubber sheet.

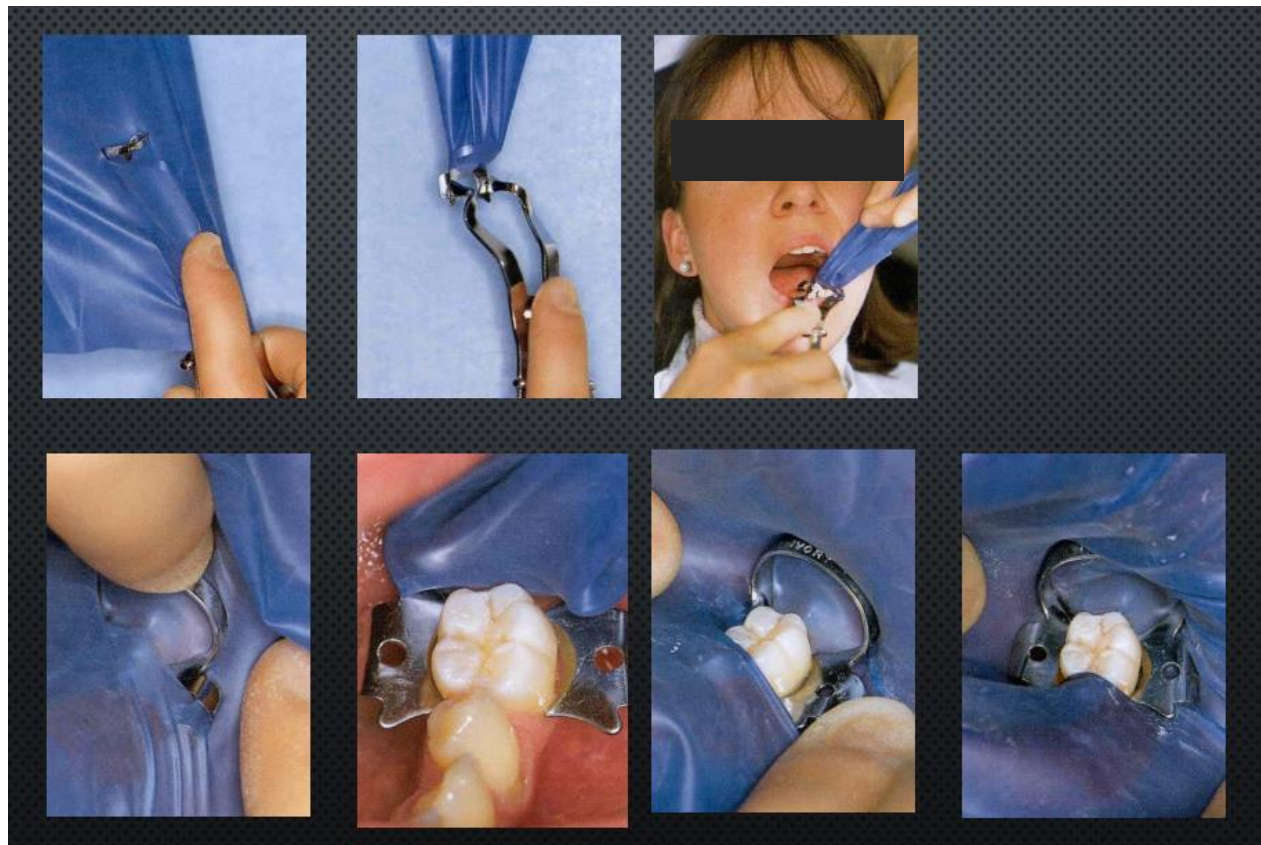

Gambar 21. Teknik bow. 


\section{SUMMARY BOX}

Syarat yang Wajib dilakukan terkait pengelolaan di ruang praktik dokter gigi:

- Pengaturan zonasi.

- Pengaturan signage (tanda/alur).

- Pengaturan volume pasien.

- Pengaturan aliran udara wajib tercapai minimal $12 \mathrm{ACH}$ dengan posisi udara bersih masuk dari arah belakang operator dan asisten (membelakangi kepala pasien) dan arah aliran udara keluar diletakkan di bawah, kurang lebih $20 \mathrm{~cm}$ dari lantai.

- Menggunakan HVE dental suction (dengan aliran pembuangan menyatu dengan dental unit), pastikan kekuatan HVE suction melebihi $100 \mathrm{cfm}$ dan bentuk corong penyedot yang efektif.

- Penggunaan rubber dam.

- Penggunaan separator wall di meja konsultasi.

Tambahan fasilitas sebagai rekomendasi bersyarat memerlukan perhatian terkait pengelolaan di ruang Praktik dokter gigi:

- Penggunaan HVE portable.

- Penggunaan lampu UV-C. 


\section{BAB III \\ ALAT PELINDUNG DIRI}

Personal protective equipment (PPE) atau yang dikenal sebagai alat pelindung diri (APD) merupakan alat yang digunakan oleh tenaga kesehatan setiap hari untuk melindungi diri mereka sendiri, pasien dan orang lain saat melakukan tindakan medis. APD ini dapat melindungi tenaga kesehatan dari segala potensi mikroorganisme atau bahan toksik yang digunakan dalam bidang kedokteran maupun kedokteran gigi.

\section{A. Jenis}

Jenis APD tergantung dari tupoksi (tugas pokok dan fungsi) masing-masing tenaga kesehatan yang terlibat dalam praktik dokter gigi. Berdasarkan CDC, tidak ditentukan level APD tersebut, tetapi level ini dibuat untuk memudahkan tenaga kesehatan mengkategorikan APD apa yang akan dipakai berdasarkan tupoksi tersebut. Daftar tupoksi dapat dilihat pada tabel 4.

Tabel 4. Level APD berdasarkan tupoksi dalam ruang praktik dokter gigi.

\begin{tabular}{lc}
\hline \multicolumn{1}{c}{ Operator } & Minimal level APD \\
\hline Asisten dalam ruang tunggu & 1 \\
Petugas kebersihan & 2 \\
Asisten dalam ruang dental unit & 3 \\
Dokter gigi & 3 \\
\hline
\end{tabular}


Tabel 5. Rekapitulasi kebutuhan alat dan bahan minimal sesuai dengan level APD. (Lammers dkk, 2020).

\begin{tabular}{lccc}
\hline \multicolumn{1}{c}{ Alat dan bahan } & Level 1 APD & Level 2 APD & Level 3 APD \\
\hline Head cap & X (opsional) & X & X \\
Google (A) & A / B & A / B & A / B \\
Face shield (B) & & & \\
Masker bedah & $\mathrm{X}$ & $\mathrm{X}$ & $\mathrm{X}$ \\
Masker N95/setara & & & $\mathrm{X}$ \\
Surgical scrub & $\mathrm{X}$ & $\mathrm{X}$ & $\mathrm{X}$ \\
Gaun sekali pakai (sampai lutut) & $\mathrm{X}$ & $\mathrm{X}$ & $\mathrm{X}$ \\
Gown all cover (Baju hazmat) & & & $\mathrm{X}$ \\
Sarung tangan dalam & & $\mathrm{X}$ & $\mathrm{X}$ \\
Sarung tangan luar & & $\mathrm{X}$ & $\mathrm{X}$ \\
Sepatu tertutup dan shoe cover & & $\mathrm{X}$ & $\mathrm{X}$ \\
Sepatu boot* & & &
\end{tabular}

* Dianjurkan tambahan

Ket: Apabila baju hazmat tidak menutupi sampai tumit kaki dan tidak memiliki sepatu boot, maka pelindung kaki dapat menggunakan shoe cover yang disebut sebagai leg cover. 

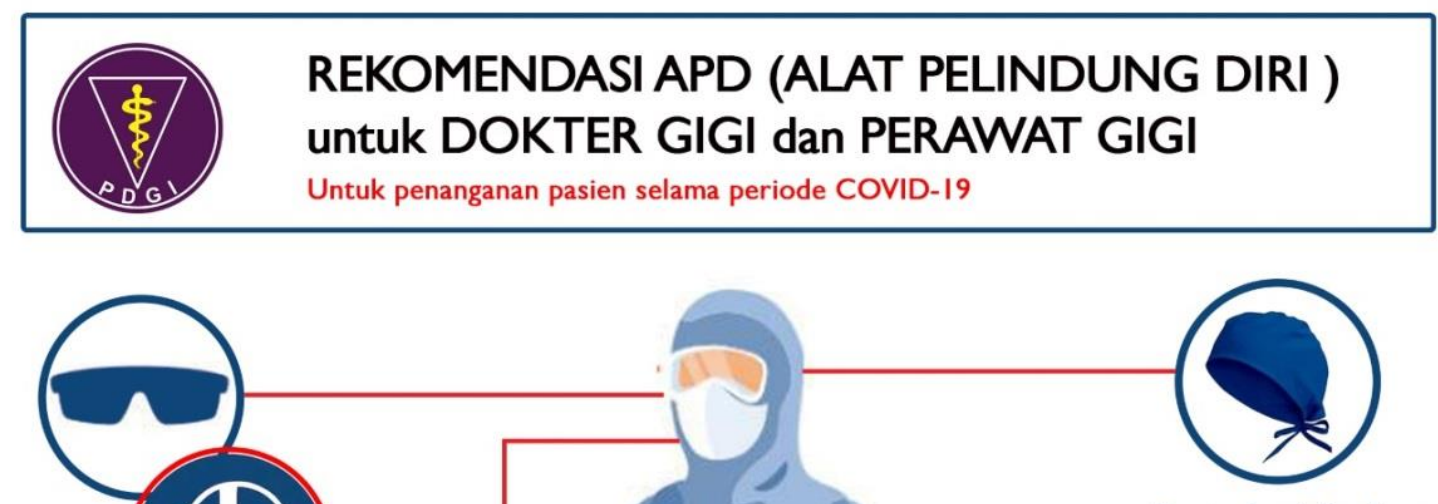

Penutup kepala/headcape

Pelindung mata atau Pelindung wajah

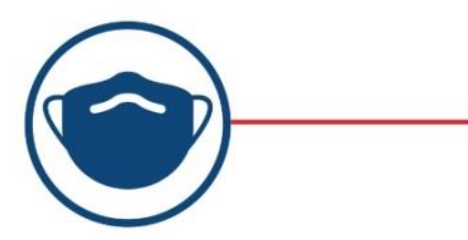

Masker N95 atau ekuivalen

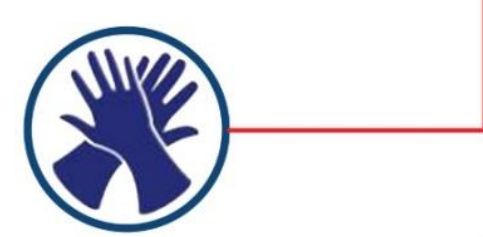

Sarung tangan double steril sekali pakai

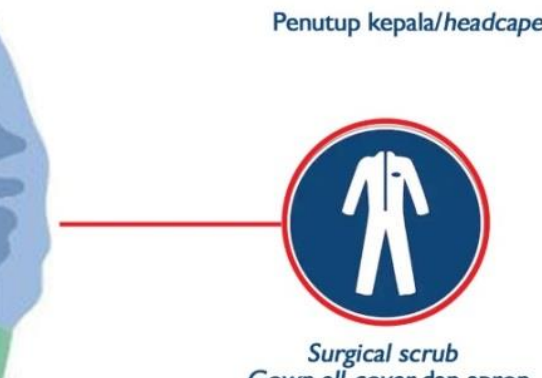

Gown all-cover dan apron

\begin{tabular}{|l|l|}
\hline KELOMPOK & LOKASI / CAKUPAN \\
\hline DOKTERGIGI & $\begin{array}{l}\text { - Ruang prosedur dan tindakan kedokteran gigi pada pasien asimtomatik / suspek atau } \\
\text { terkonfirmasi COVID-19 } \\
\text { PERAWAT GIGI }\end{array}$ \\
& Tindakan kedokteran gigi yang menimbulkan penyebaran droplet atau aerosol \\
\hline
\end{tabular}

\section{PDGI lawan COVID-19}

\#stayathome

\#physicaldistancing

\#tidakmudik

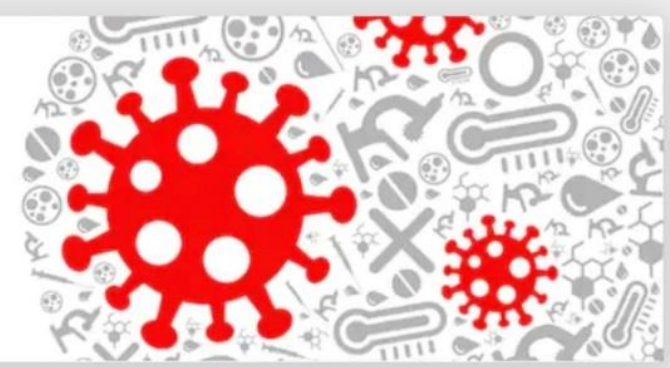


PELINDUNG MATA ATAU FACE SHIELD

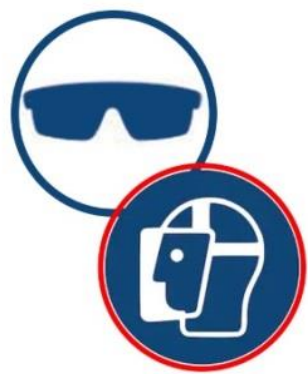

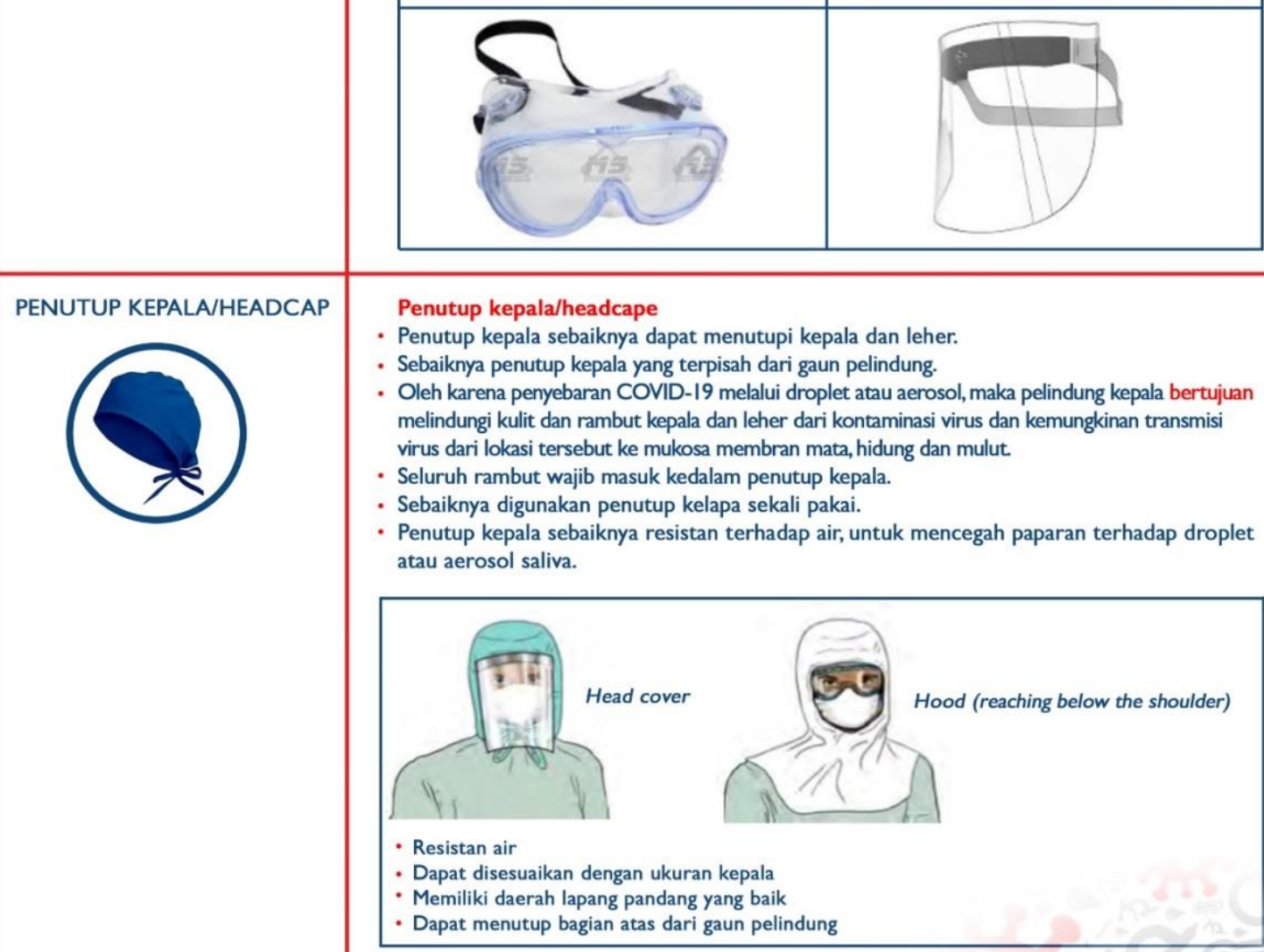

Pelingung mata atau face shiled ditujukan untuk melindungi membran mukosa dari paparan droplet atau aerosol yang timbul saat melakukan tindakan perawatan gigi mulut. Proteksi membran mukosa dari mata, hidung dan mulut merupakan standar dari penanganan pasien yang memiliki infeksi dengan penyebaran melalui droplet. Patogen dalam droplet menyebar melalui droplet dengan ukuran lebih dari $5 \mu \mathrm{m}$, sedangkan ukuran aerosol sebesar $0.01-0.05 \mu \mathrm{m}$.

jika menggunakan pelindung mata atau face shiled yang dapat dibersihkan, lakukan prosedur dekontaminasi menggunakan bahan disinfeksi yang dianjurkan.

\begin{tabular}{|c|c|}
\hline GOOGLES & FACE SHIELD \\
\hline - Seal baik terhadap kulit wajah & $\begin{array}{c}\text { Terbuat dari plastik tembus pandang sehing- } \\
\text { - Frame fleksibel yang dapat menutup seluruh }\end{array}$ \\
\begin{tabular}{l} 
ga merikan visibilitas baik bagi tenaga \\
\hline
\end{tabular}
\end{tabular}

- Frame fleksibel yang dapat menutup seluruh

kontur wajah tanpa menekan terlalu dalam kesehatan dan pasien

sekitarnya

- Resistan terhadap pembentukkan embun

atau scratch ("baret")

Memiliki tali ikat kepala yang dapat

disesuaikan dengan ukuran masing-masing

- Dapat digunakan secara berulang setelah prosedur disinfeksi

\section{\begin{tabular}{l|l}
\hline Standar WHO: & Standar WHO:
\end{tabular}}

EU Standard directive 86/686/EEC, $\quad$ EU Standard directive $86 / 686 / \mathrm{EEC}$,

EN 166/2002 atau ANSI/ISEA Z87.1-2010 EN 166/2002 atau ANSI/ISEA Z87.1-2010

\section{PDGI lawan COVID-19}


FLUID RESISTAN MEDICAL atau MASKER BEDAH

- Resistensi tinggi terhadap air

- Mudah untuk bernapas

- Seal yang baik terhadap kontur wajah

- Bentuk masker yang tidak berkontak langsung terhadap hidung atau mulut (bentuk "duckbill" atau "cup shape")

Standar WHO masker bedah: EN 14683 Tipe IIR preformance atau ASTM F2 I00 level 2 atau level 3 atau ekuivalen

\section{PDGI lawan COVID-19}

SATGAS PB-PDGI 


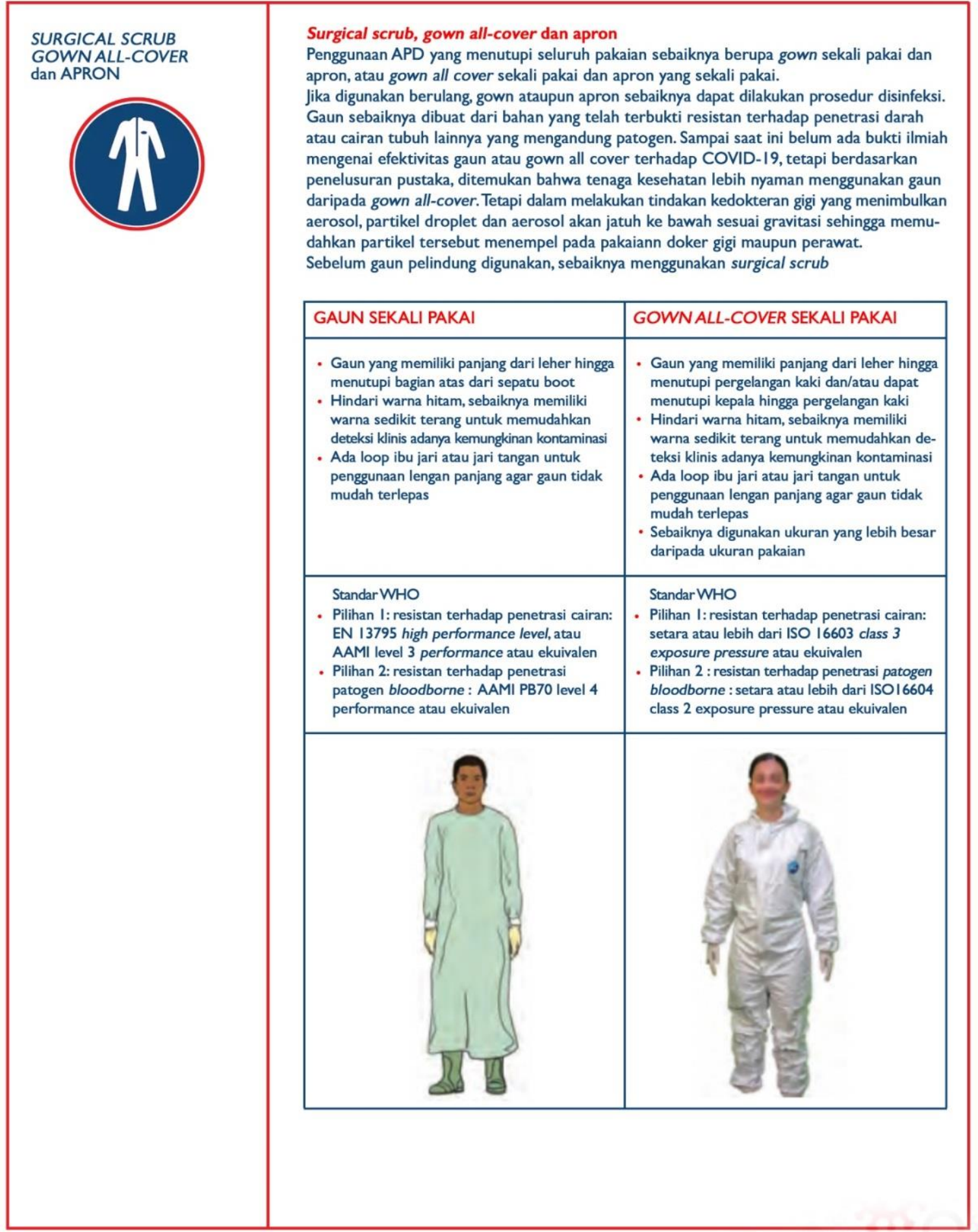

\section{PDGI lawan COVID-19}




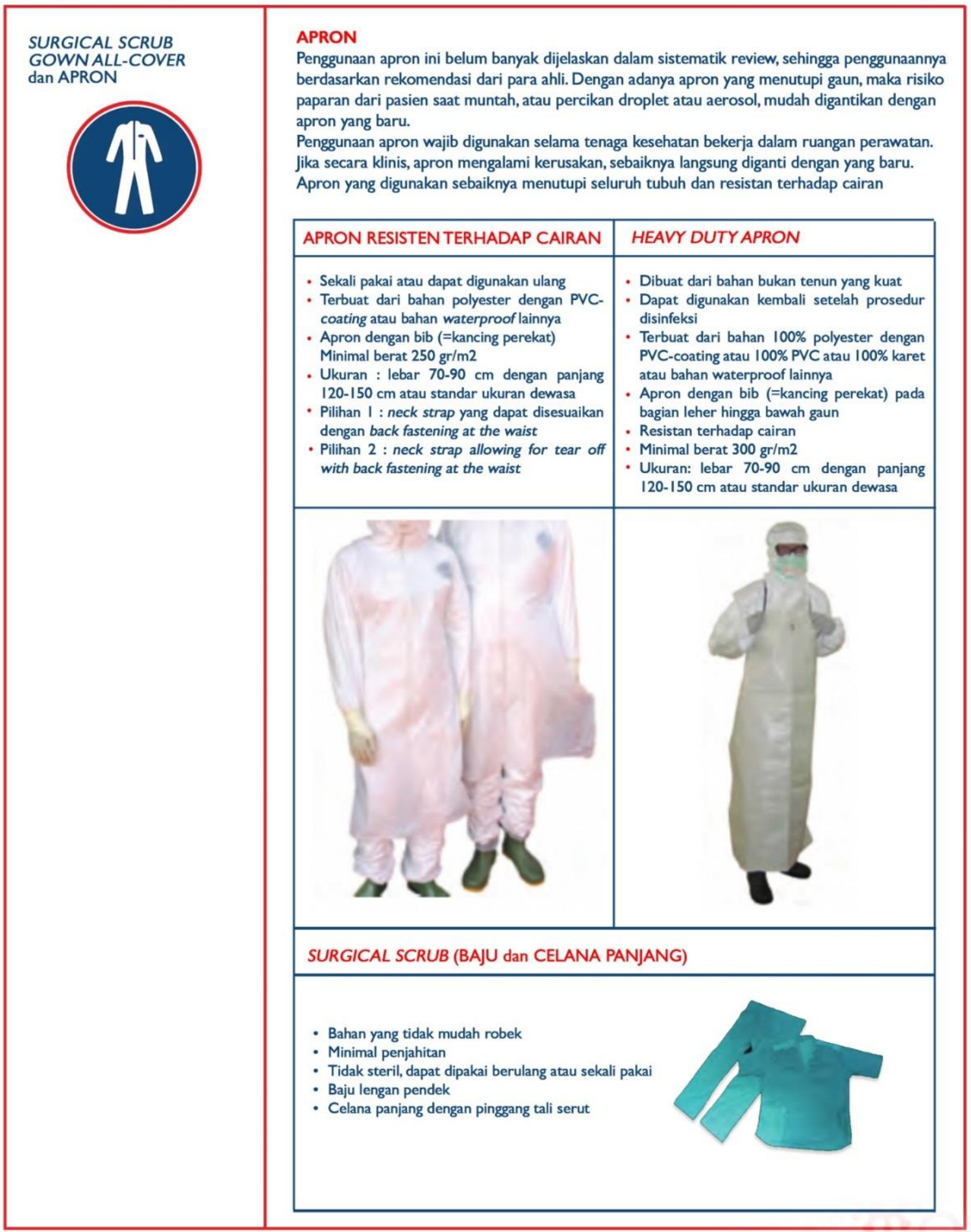

\section{PDGI lawan COVID-19}

SATGAS PB-PDGI 


\begin{tabular}{|l|l|}
\hline SARUNG TANGAN DOUBLE \\
STERIL SEKALI PAKAI
\end{tabular}$\quad \begin{aligned} & \text { Sarung tangan steril sekali pakai } \\
& \text { Sebaiknya digunakan sarung tangan biasa double atau sarung tangan bedah latex untuk } \\
& \text { menghindari risiko transmisi virus ke tenaga kesehatan akibat adanya perforasi atau } \\
& \text { kerusakan sarung tangan saat tindakan perawatan gigi mulut atau akibat bahan disinfeksi } \\
& \text { seperti klorin. Penggunaan sarung tangan double atau sarung tangan bedah ini tentunya dapat } \\
& \text { mengurangi rasa sensasi taktil saat palpasi, tetapi hal ini akan dapat menjadi terbiasa oleh } \\
& \text { tenaga kesehatan. Sarung tangan yang digunakan lebih dari dua, tidak dianjurkan karena akan } \\
& \text { menyebabkan hambatan dalam pergerakan dan kompleksitas saat melepaskan sarung tangan. } \\
& \text { Sarung tangan sebaiknya bagian luar memiliki panjang yang cukup mencapai idelanya } \\
& \text { pertengahan lengan bawah. Untuk melindungi lebih baik, sarung tangan pertama (bagian } \\
& \text { dalam) harus tertutup bagian lengan dari gaun dan sarung tangan kedua harus menutupi } \\
& \text { bagian ujung lengan dari gaun. Sarung tangan tidak boleh ditutupi menggunakan selotip karena } \\
& \text { akan menyebabkan hambatan saat melepaskan sarung tangan dan gaun. Penggunaan sarung } \\
& \text { tangan sebaiknya diganti yang baru saat melakukan tindakan ke pasien lain. Tetapi jika tidak } \\
& \text { mungkin, maka lakukan prosedur disinfeksi, lepaskan sarung tangan kedua, lalu lakukan } \\
& \text { kembali proses disinfeksi dan gunakan sarung tangan kedua yang baru. Bahan disinfeksi yang } \\
& \text { digunakan adalah hand rubs berbahan alkohol 70\%. Sarung tangan berbahan nitril lebih } \\
& \text { ditoleransi baik daripada sarung tangan berbahan dasar latex. Bahan nitril ini sangat baik } \\
& \text { karena tahan terhadap bahan disinfeksi seperti klorin. Disamping itu, populasi tenaga } \\
& \text { kesehatan yang alergi latex didunia sebanyak I2\%, menyebabkan dermatitis kontak, iritasi } \\
& \text { kulit, gatal, sensasi terbakar maupun alergi. }\end{aligned}$

\section{SARUNG TANGAN}

- Berbahan nitril atau latex

- Sarung tangan kedua (terluar) sebaiknya mencapai

pertengahan lengan bawah (minimal $280 \mathrm{~mm}$ dari

panjang total)

- Tersedia berbagai ukuran

Standar WHO

- EU standard directive 93/42/EEC class I, EN 45

- EU standard directive 89/686/EEC category III. EN 374

- ANSI/ISEA 105-2011

- ASTM D6319-10 atau ekuivalen

\begin{tabular}{|l|} 
\\
\hline SEPATU BOOT ATAU \\
SEPATU TERTUTUP DENGAN \\
PENUTUP SEKALI PAKAI
\end{tabular}

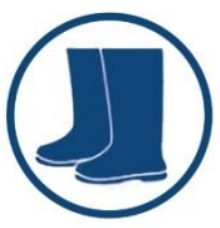

Sepatu boot atau sepatu tertutup dengan pembungkus sekali pakai

Penggunaan sepatu boot atau pembungkus sepatu dapat mencegah kontaminasi patogen virus dalam ruang perawatan dokter gigi. Sepatu boot resistan terhadap cairan sebaiknya digunakan dibandingkan sepatu biasa, karena sepatu boot mudah dibersihkan dan disinfeksi. Disamping itu, sepatu boot dapat melindungi tenaga kesehatan dari alat tajam atau bahan korosif saat terjatuh. Jika sepatu boot tidak tersedia, digunakan sepatu yang tertutup dan dibungkus oleh pembungkus sepatu yang tidak licin juga dapat menggantikan sepatu boot. Sepatu boot tidak perlu diganti dan dapat digunakan terus setelah prosedur disinfeksi.

\section{SEPATU BOOT RESISTEN TERHADAP CAIRAN}

- Tidak licin, dengan permukaan PVC

- Setinggi atau mencapai lutut, lebih tinggi daripada bagian bawan dari gaun (disarankan posis dokter gigi tegak saat mengerjakan pasien, dibandingkan posisi duduk karena akan menyebabkan gaun terbuka)

- Sebaiknya diipilih warna yang terang agar dapat dideteksi jika ada kontaminasi

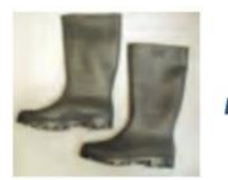

Boots

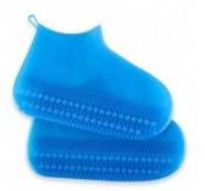

Shoe cover

\section{PDGI lawan COVID-19}




\section{B. Donning dan Doffing APD}

Donning APD adalah teknik memasang atau menggunakan APD. Tahapan teknik pemasangan APD, dapat meminimalkan atau bahkan mencegah penularan semua jenis mikroorganisme. Sebaiknya dokter gigi memasang poster teknik pemasangan ini di ruang APD untuk memudahkan pemasangan yang akurat. Doffing APD adalah teknik melepaskan APD. Tahapan teknik melepaskan APD sangat penting dipahami oleh tenaga kesehatan karena saat melepaskan APD, sangat berisiko tertular dari mikroorganisme yang menempel di APD tersebut.

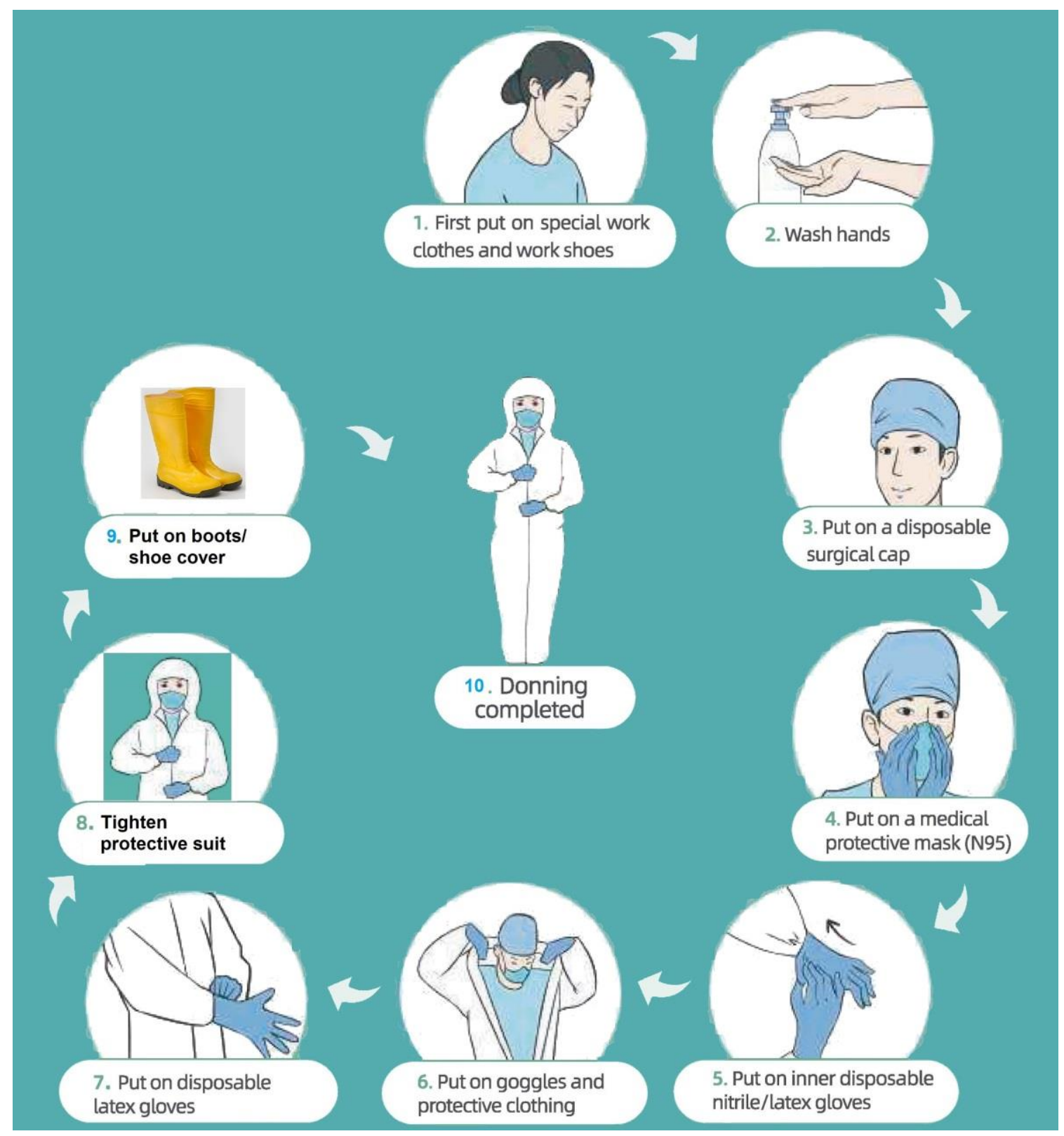

Gambar 22. Tahapan pemasangan APD (modifikasi dari Liang, 2020). 
Tahapan pemasangan APD

1) Baju

- $\quad$ Pasang baju dan celana surgical scrub.

2) Lakukan cuci tangan menggunakan hand sanitizer berbahan dasar alkohol $70 \%$.

3) Head cover

- Pasangkan head cover disposible hingga menutupi seluruh rambut sisi depan dan belakang. Bagi yang berambut panjang, ikat rambut sehingga dapat tertutup dalam head cover.

4) Masker atau respirator

a. Masker N95/setara

- Gunakan cup masker terlebih dahulu dan sangkutkan tali masker ke kepala.

- Posisikan masker agar menutupi bagian atas hidung, mulut dan bawah dagu.

- Tekan daerah tepi masker diatas hidung.

- $\quad$ Cek kembali posisi masker dan tepinya.

b. Surgical mask

- $\quad$ Posisikan tepi tengah atas masker di notch hidung (tulang hidung diatara kedua mata).

- Pasangkan tali pengikat ke kepala.

- $\quad$ Tarik dan pentangkan masker sehingga menutupi bawah dagu.

- $\quad$ Cek kembali posisi masker dan tepinya.

5) Sarung tangan dalam (sarung tangan pertama)

- Pasang sarung tangan pertama di bagian dalam. Tepi sarung tangan dalam wajib tertutup oleh tepi lengan gaun sekali pakai atau baju hazmat.

6) Baju gaun sekali pakai atau baju hazmat, kacamata atau face shield

- Pasangkan baju hazmat yang menutupi dari leher ke lutut, tangan sampai pundak dan ikat di belakang.

- Jika tersedia dalam set baju hazmat, maka gunakan leg cover.

- Pasang kacamata atau face shield yang disesuaikan dengan ukuran wajah dan kepala.

7) Sarung tangan luar (sarung tangan kedua)

- Pasang sarung tangan kedua di bagian luar. Tepi sarung tangan luar wajib menutupi tepi luar dari lengan baju. 
8) Baju

- Jika baju hazmat menyatu dengan penutup kepala (hood), pasangkan hood menutupi kepala.

- Kencangkan dan kancingkan atau rekatkan velcrow baju hazmat sehingga rapat tertutup.

9) Sepatu tertutup atau boot

- Sepatu tertutup, ditutupi dengan shoe cover atau leg cover atau menggunakan sepatu boot yang sesuai dengan ukuran.

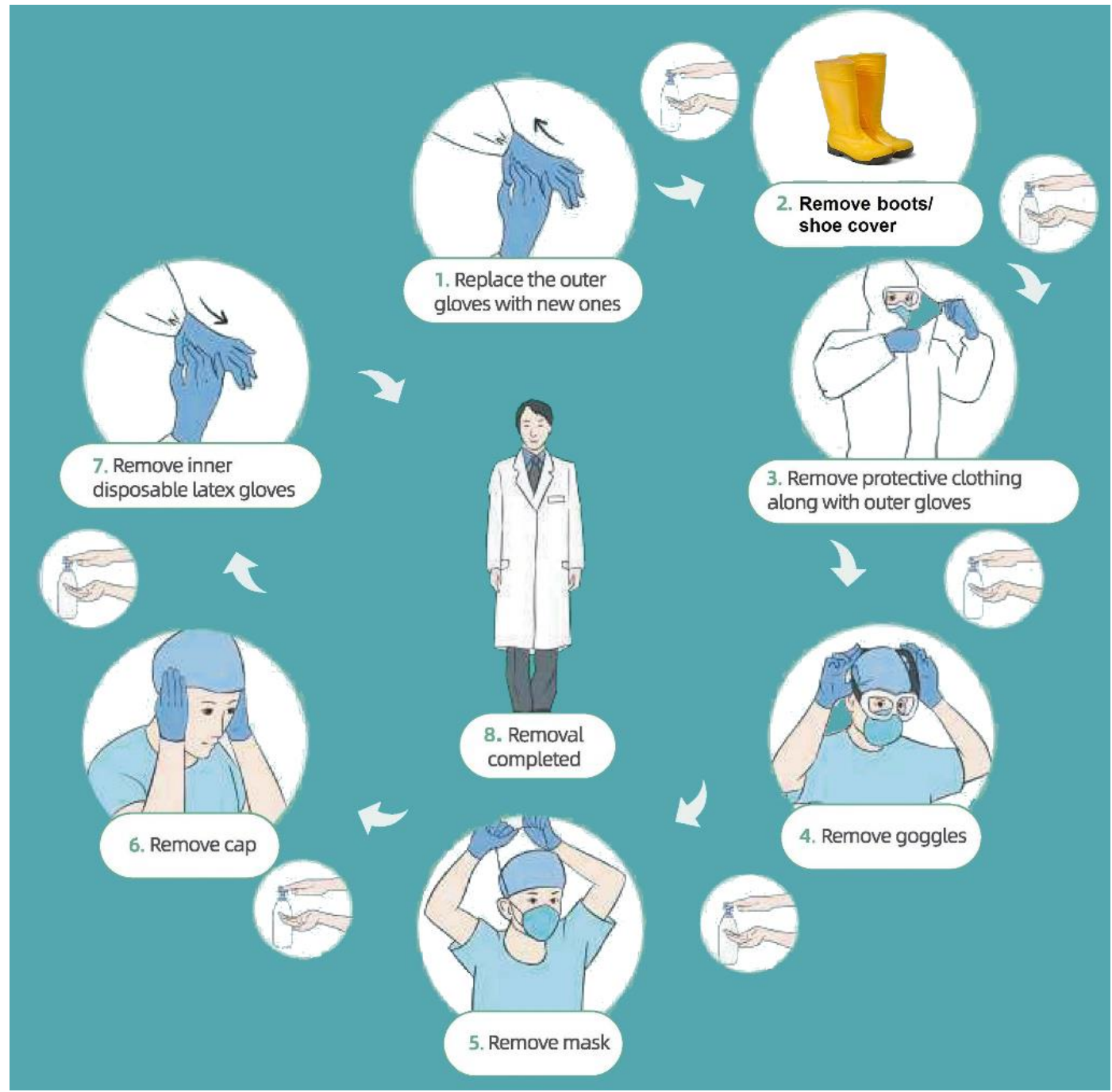

Gambar 23. Tahapan pelepasan APD (modifikasi dari Liang, 2020).

Tahapan pelepasan APD (Tahapan pelepasan APD, wajib mengikuti urutan dan setiap memasuki urutan selanjutnya, wajib didahului dengan cuci tangan sesuai WHO menggunakan disinfektan) sebagai berikut: 
1) Sarung tangan luar (sarung tangan kedua)

- PERHATIKAN: sarung tangan luar merupakan barang yang paling terkontaminasi.

- Jika tangan atau kulit (tidak sengaja) berkontak dengan barang paling terkontaminasi, segera cuci tangan menggunakan hand sanitizer berbahan dasar alkohol $70 \%$.

- Gunakan jari tangan lain untuk melepaskan sarung tangan luar tanpa berkontak dengan sarung tangan dalam.

Lakukan cuci tangan menggunakan hand sanitizer berbahan dasar alkohol $70 \%$.

2) Sepatu dengan shoe cover atau sepatu boot

- PERHATIKAN: shoe cover dan sepatu boot merupakan barang yang juga paling sering terkontaminasi.

- Jika tangan atau kulit (tidak sengaja) berkontak dengan barang paling terkontaminasi, segera cuci tangan menggunakan hand sanitizer berbahan dasar alkohol $70 \%$.

- Shoe cover dibuka dan dimasukkan ke dalam container (wadah) khusus barang kontaminasi.

- Lepaskan sepatu boot, hati-hati agar tidak terjatuh saat melepas sepatu tersebut.

- Selanjutnya sepatu boot didisinfeksi.

Lakukan cuci tangan menggunakan hand sanitizer berbahan dasar alkohol $70 \%$.

3) Baju gaun sekali pakai/baju hazmat

- $\quad$ PERHATIKAN: baju juga merupakan barang yang paling terkontaminasi.

- Jika tangan atau kulit (tidak sengaja) berkontak dengan barang paling terkontaminasi, segera cuci tangan menggunakan hand sanitizer berbahan dasar alkohol $70 \%$.

- Lepaskan tali pengikat/restletting/kancing/velcrow tanpa menyentuh kulit.

- Lepaskan baju dari kepala, arah leher, pundak dengan hanya menyentuh bagian dalam baju.

- Gulungkan baju agar sisi dalam baju berada di bagian luar.

- Jika baju akan digunakan kembali, letakkan dalam wadah khusus barang kontaminasi (berisi air dan detergen) yang digunakan ulang dan kemudian dilakukan disinfeksi.

- Jika baju sekali pakai, masukkan dalam kantong plastik limbah (berwarna kuning). 
Lakukan cuci tangan menggunakan hand sanitizer berbahan dasar alkohol $70 \%$.

4) Kacamata atau face shield

- $\quad$ PERHATIKAN: kacamata atau face shield juga merupakan barang yang paling terkontaminasi.

- Jika tangan atau kulit (tidak sengaja) berkontak dengan barang paling terkontaminasi, segera cuci tangan menggunakan hand sanitizer berbahan dasar alkohol $70 \%$.

- Lepaskan kacamata atau face shield dengan cara memegang tali pengikat di kepala.

- Jika operator menggunakan kacamata baca, setelah melepaskan kacamata baca, jangan lupa agar dicuci menggunakan air dan detergen.

- Jika kacamata atau face shield akan digunakan kembali, letakkan dalam wadah khusus barang kontaminasi yang digunakan ulang dan kemudian dilakukan disinfeksi. Jika kacamata atau face shield hanya dimiliki dalam jumlah terbatas, maka lakukan disinfeksi sebelum melepaskan baju dan sarung tangan dalam (sarung tangan pertama).

Lakukan cuci tangan menggunakan hand sanitizer berbahan dasar alkohol $70 \%$.

5) Masker

- $\quad$ PERHATIKAN: masker juga merupakan barang yang paling terkontaminasi.

- Masker dilepaskan dengan cara memegang tali pengikat dikepala, tanpa menyentuh kulit.

- Jika masker akan digunakan kembali, letakkan dalam wadah khusus barang kontaminasi yang digunakan ulang dan kemudian dilakukan disinfeksi. Jika masker sekali pakai, masukkan dalam kantong plastik limbah.

Lakukan cuci tangan menggunakan hand sanitizer berbahan dasar alkohol $70 \%$.

6) Head cover

- Lepaskan head cover tanpa menyentuh rambut dan buang ke kantong plastik limbah.

Lakukan cuci tangan menggunakan hand sanitizer berbahan dasar alkohol $70 \%$.

7) Sarung tangan dalam (sarung tangan pertama)

- Lepaskan sarung tangan dalam dan buang ke kantong plastik limbah. 
Jika tidak tersedia ruangan khusus untuk pelepasan APD, CDC merekomendasikan melepas APD (doffing) dan sarung tangan di lakukan ruang dental unit. Sedangkan untuk melepas pelindung wajah/goggle/face shield dan masker dilakukan di luar ruang tindakan pasien. Apabila semua APD sudah dilepas, maka tenaga kesehatan wajib melakukan kebersihan tangan.

\section{SUMMARYBOX}

Jenis APD tergantung dari tupoksi (tugas pokok dan fungsi)

1) Level 1: asisten dalam ruang tunggu

2) Level 2: petugas kebersihan

3) Level 3: dokter gigi dan asisten dalam ruang dental unit

- Donning APD adalah tehnik memasang atau menggunakan APD.

- Doffing APD adalah tehnik melepaskan APD.

- Seluruh tahapan donning dan doffing sebaiknya dipasang di dinding ruang donning dan doffing APD.

- Tahapan teknik melepaskan APD sangat penting dipahami oleh tenaga kesehatan karena saat melepaskan APD, sangat berisiko tertular dari mikroorganisme yang menempel di APD tersebut.

Tahapan donning APD

1) Baju surgical scrub

2) Cuci tangan

3) Head cover

4) Masker

5) Sarung tangan dalam

6) Baju gaun sekali pakai/baju hazmat

7) Sarung tangan luar

8) Kacamata atau face shield

9) Kencangkan baju hazmat

10) Sepatu boot atau shoe cover

Tahapan doffing APD (selalu lakukan cuci tangan menggunakan alkohol 70\% diantara tiap tahapan)

1) Sarung tangan luar

2) Sepatu dengan shoe cover atau sepatu boot

3) Baju gaun sekali pakai/baju hazmat

4) Kacamata atau face shield

5) Masker

6) Head cover

7) Sarung tangan dalam

Jika tidak tersedia ruangan khusus untuk pelepasan APD, maka APD dan sarung tangan dilepas dalam ruang dental unit. Sedangkan untuk melepas pelindung wajah/goggle/face shield dan masker dilakukan di luar ruang dental unit. 


\section{BAB IV \\ DISINFEKSI}

A. Definisi

Sterilisasi menggambarkan suatu proses menghancurkan atau meng- hilangkan semua bentuk kehidupan mikroorganisme yang dilakukan pada fasilitas kesehatan. Sterilisasi dapat dilakukan secara fisik atau kimiawi, steam under pressure (penguapan di bawah tekanan), panas kering, gas EtO (etilen dioksida), gas hidrogen peroksida, dan bahan kimia cair yang merupakan agen sterilisasi utama yang sering digunakan.

Disinfeksi menggambarkan suatu proses yang menghilangkan banyak atau semua mikroorganisme patogen, kecuali spora bakteri pada benda mati. Dalam pengaturan layanan kesehatan, objek biasanya didisinfeksi dengan cairan kimia atau pasteurisasi basah. Bahan yang digunakan sebagai bahan disinfeksi disebut disinfektan.

Disinfektan tingkat rendah dapat membunuh sebagian besar bakteri vegetatif, beberapa jamur, dan beberapa virus dalam periode waktu yang singkat (kurang dari 10 menit).

Disinfektan tingkat menengah dapat membunuh mikroorganisme, bakteri vegetatif, sebagian besar virus, dan sebagian besar jamur, tetapi tidak membunuh spora bakteri.

Disinfektan tingkat tinggi adalah disinfektan yang pada konsentrasi yang sama tetapi dengan periode paparan yang lebih pendek (contoh, 20 menit untuk 2\% glutaraldehyde), akan membunuh semua mikroorganisme kecuali sejumlah besar spora bakteri. Jika ingin membunuh spora, maka diperlukan paparan waktu yang lebih lama 3-12 jam.

Germisida adalah agen yang dapat membunuh mikroorganisme, terutama mikroorganisme patogen. Istilah germisida meliputi antiseptik dan disinfektan.

Antiseptik adalah germisida yang dapat dipakai ke jaringan hidup atau kulit. Secara umum, antiseptik hanya digunakan pada kulit dan bukan untuk disinfeksi permukaan.

Disinfektan adalah antimikroba yang diterapkan hanya pada benda mati dan disinfektan tidak digunakan untuk antisepsis kulit karena dapat melukai kulit dan jaringan lain. 
Berdasarkan The CDC Guideline for Handwashing and Hospital Environmental Control; Guidelines for the Prevention of Transmission of Human Immunodeficiency Virus (HIV) and Hepatitis B Virus (HBV) to Health-Care and Public-Safety Workers; Guideline for Environmental Infection Control in Health-Care Facilities dikenal beberapa terminologi untuk menunjukkan klasifikasi disinfeksi berdasarkan barang yang akan di sterilkan, sebagai Critical item, Semicritical item dan Non critical item.

\section{B. Kategori Barang (Item) Yang Terkontaminasi}

\section{Critical items}

Barang-barang kritis yang memberikan risiko tinggi terjadinya infeksi jika terkontaminasi mikroorganisme. Semua benda yang akan masuk ke jaringan tubuh harus steril karena mikroorganisme apapun dapat berisiko menularkan penyakit. Kategori ini mencakup instrumen bedah, kateter jantung dan urin, implan, dan probe ultrasonik (scaler, handpiece, bur, probe, alat diagnostik dental). Sebagian besar barang dalam kategori ini harus dibeli steril atau disterilkan dengan uap panas jika memungkinkan.

Benda yang peka terhadap panas dapat disterilkan dengan ethylene oxide, gas hidrogen peroksida; atau jika metode lain tidak sesuai dapat dengan alat sterilisasi kimia cair (contoh alkohol). Germisida yang berasal dari bahan kimia termasuk formulasi berbasis glutaraldehyde $\geq 2,4 \%$, glutaraldehyde $0,95 \%$ dengan fenol/phenate $1,64 \%$, hidrogen peroksida $\left(\mathrm{H}_{2} \mathrm{O}_{2}\right)$ yang distabilkan $7,5 \%$, hidrogen peroksida $\left(\mathrm{H}_{2} \mathrm{O}_{2}\right) 7,35 \%$ dengan asam perasetat $0,23 \%$, dan asam perasetat $0,08 \%$ dengan hidrogen peroksida $\left(\mathrm{H}_{2} \mathrm{O}_{2}\right) 1,0 \%$. Keberhasilan sterilisasi kimia cair sangat baik dilakukan sebelum perawatan dengan mengikuti pedoman mengenai konsentrasi, waktu kontak, suhu, dan $\mathrm{pH}$.

\section{Semicritical items}

Barang semi-kritis adalah barang yang berkontak dengan mukosa atau kulit yang tidak utuh (terjadi perlukaan atau kontak pada mukosa). Kategori ini termasuk alat pernapasan dan anestesi, beberapa endoskopi. Barang semi-kritis minimal membutuhkan disinfeksi tingkat tinggi menggunakan disinfektan kimia. Glutaraldehyde, hidrogen peroksida, dan asam perasetat dengan hidrogen peroksida diakui oleh Food and Drug Administration (FDA).

\section{Non critical items}

Barang non-kritis adalah barang yang bersentuhan dengan kulit utuh tetapi bukan mukosa. Kulit yang utuh dapat bertindak sebagai penghalang efektif untuk 
sebagian besar mikroorganisme. Dalam pedoman ini, barang non-kritis dibagi menjadi barang perawatan untuk pasien non-kritis dan barang yang terdapat di permukaan lingkungan non-kritis, contoh pispot, manset pengukur tekanan darah, kruk dan komputer. Pada kelompok ini, disinfektan yang digunakan mengandung bahan detergen atau alkohol.

\section{Jenis dan metode sterilisasi dan disinfeksi}

Protokol sterisilasi pada praktik dokter gigi selama New Normal COVID-19 tidak berbeda untuk patogen respiratorius. Lakukan protokol pembersihan, disinfeksi, dan sterilisasi secara rutin, dan ikuti rekomendasi untuk sterilisasi dan disinfeksi pasien, ruang, alat sesuai dengan rekomendasi dari the Guidelines for Infection Control in Dental Health-Care Settings 2003 (May, 2019). Disinfeksi dapat dibagi berdasarkan bahan aktif dan metode.

\section{Bahan aktif}

Sekarang banyak produk di pasaran yang mengandung bahan yang mempunyai kemampuan untuk mengatasi penyebaran virus SARS-CoV-2. Berdasarkan CDC (2020), pengembangan bahan sterilisasi dan disinfeksi sebanyak kurang lebih 400 variasi untuk berbagai mikroorganisme.

Tabel 6. Daftar disinfektan yang efektif untuk membunuh Human coronanvirus spesifik SARS-CoV-2 (List N CDC, 2020).

\begin{tabular}{lcccc}
\hline No $\quad \begin{array}{c}\text { Lama } \\
\text { Bahan Aktif }\end{array}$ & $\begin{array}{c}\text { Perkontak } \\
\text { (menit) }\end{array}$ & $\begin{array}{c}\text { Health } \\
\text { care }\end{array}$ & $\begin{array}{c}\text { Pemakaian } \\
\text { Institi- } \\
\text { onal }\end{array}$ & $\begin{array}{c}\text { Residen- } \\
\text { tial }\end{array}$ \\
\hline 1 Quaternary ammonium & 10 & $\mathrm{X}$ & $\mathrm{X}$ & $\mathrm{X}$ \\
2 Quaternary ammonium; \\
$\begin{array}{l}\text { Isopropanol (Isopropyl } \\
\text { alcohol) }\end{array}$ & 0,5 (30 detik) & $\mathrm{X}$ & $\mathrm{X}$ & $\mathrm{X}$ \\
3 Sodium hypochlorite & 5 & $\mathrm{X}$ & $\mathrm{X}$ & $\mathrm{X}$ \\
4 L-Lactic Acid & 5 & $\mathrm{X}$ & $\mathrm{X}$ & $\mathrm{X}$ \\
5 Peroxyacetic acid & 1 & $\mathrm{X}$ & $\mathrm{X}$ & $\mathrm{X}$ \\
$\begin{array}{l}\text { (Peracetic acid) } \\
6 \text { Phenolic }\end{array}$ & 10 & $\mathrm{X}$ & $\mathrm{X}$ & $\mathrm{X}$ \\
7 Ethanol (Ethyl alcohol) & 0,5 (30 detik) & $\mathrm{X}$ & $\mathrm{X}$ & \\
8 lodine solution & 1 & & & \\
\hline
\end{tabular}




\section{Metode disinfeksi}

Metode disinfeksi dapat menggunakan pencucian barang menggunakan air detergen, uap panas, sinar (matahari, UV-C), swab atau spray (semprot) menggunakan bahan berbasis disinfektan, serta fogging (mist/kabut)

a. Disinfeksi alat yang sudah dipakai

Disinfektan permukaan alat dapat menggunakan campuran air dan detergen atau sodium hipoklorit $5 \%$ dengan perbandingan 1:100 (konsentrasi final sebesar 0,05\%) selama 1 menit. Untuk barang dengan permukaan yang kecil, dapat dibersihkan menggunakan etanol $70 \%$ atau detergen dan air selama 10 menit.

Instrumen. Instrumen bedah dan instrumen lain yang biasanya berkontak dengan jaringan lunak atau tulang (misalnya, ekstraksi forceps, pisau bedah, chisel (pahat tulang), scaler periodontal, dan bur bedah, alat diagnostik) digolongkan critical item. Instrumen yang tidak untuk menembus jaringan lunak mulut atau tulang (seperti burniser (kondensor amalgam) dan three way syringe), tetapi tetap dapat berkontak dengan mukosa, diklasifikasikan sebagai semi critical item dan disterilkan dengan panas atau sekurang-kurangnya dengan air detergen, etanol atau disinfektan kimia lainnya (Tabel 6 tentang daftar disinfektan).

Handpiece. Khusus handpieces yang tahan panas, dapat disinfeksi menggunakan uap tekanan tinggi (autoklaf), uap kimia (formaldehida), dan panas kering (contoh $320^{\circ} \mathrm{F}$ atau $160^{\circ} \mathrm{C}$ selama 2 jam). Handpiece yang tidak tahan panas, dapat didisinfeksi alkohol $70 \%$ atau hidrogen peroksida $1 \%$.

Cetakan gigi atau rahang. Cetakan gigi atau rahang, dilakukan disinfeksi menggunakan sodium hipoklorit $2,5 \%$ dengan cara disemprotkan ke atas permukaan cetakannya, sebelum dikirim ke laboratorium. Jika protesa yang sedang dikerjakan di pasien, maka disinfeksi dapat menggunakan povidon iodin 1\%, atau hidrogen peroksida 1\%, atau klorin dioksida 2,5\% (Tabel 6 tentang daftar disinfektan).

Baju. Bahan pakaian yang dapat dipakai ulang (surgical scrub, baju hazmat, leg cover, plastic shoe cover), disinfeksi dengan cara mencuci menggunakan detergen dan air (direndam 30 menit). Sebaiknya penggunaan jenis bahan pakaian ini mengikuti anjuran yang berlaku seperti bahan yang tidak mudah tembus air dan kedap pori terhadap partikel virus. 
Masker. Disinfeksi masker N95/setara dengan menggunakan cahaya UV-C atau sinar matahari atau menggunakan uap panas dengan suhu $70 \circ \mathrm{C}$. Penggunaan alkohol $70 \%$ secara semprot kemudian didiamkan dahulu hingga kering, juga dapat menjadi alternatif untuk disinfeksi dari masker N95/setara.

Kacamata (goggles) atau face shield dan sepatu boot. Disinfeksi kacamata, face shield, sepatu boot dilakukan setiap selesai pasien dan setelah disinfeksi dengan cara dibasuh menggunakan air sabun atau kain lap yang dibasahi alkohol. Tidak disarankan menggunakan dalam bentuk semprot.

Ruangan. Pembersihan lingkungan kerja dan lingkungan lain meliputi ruang tunggu pasien, pintu, jendela, kursi, dental unit, dan sebagainya, dengan menggunakan swab (kain lap) alkohol 70\%, atau benzalkonium klorida 2\% (karbol), yang sudah banyak dijual dalam produk pasaran pembersih lantai. Walaupun pemakaian jangka panjang harus dipertimbangkan karena dapat menimbulkan korosi pada bahan metal. Pastikan bahwa prosedur pembersihan dan disinfeksi lingkungan diikuti secara konsisten dan benar setiap pasien usai dikerjakan. Lihat daftar $\mathrm{N}$ di situs web EPA (https://www.epa.gov/pesticide-registration/ list-ndisinfectants-use-against-SARS-CoV-2-COVID-19) untuk disinfek- tan yang terdaftar memenuhi syarat di bawah program patogen virus SARS-CoV-2.

Pembersihan dan disinfeksi area klinik gigi dilakukan setelah pasien (tanpa, dicurigai atau terkonfirmasi COVID-19) keluar dari ruang dental unit dan pasien selanjutnya baru dapat masuk setelah 15 menit pembersihan. Untuk membersihkan dan mendisinfeksi operasi gigi setelah pasien dengan COVID-19, dokter dan perawat harus menunda masuk ke dalam ruang operasi/kerja sampai waktu yang cukup untuk perubahan udara (minimal 1530 menit) dalam menghilangkan partikel aerosol yang berpotensi menularkan. Tidak terlalu disarankan untuk eradikasi bakteri, dengan melakukan disinfeksi ruang kerja gigi menggunakan fogging dengan bahan kimia seperti formaldehida, agen berbasis fenol, atau senyawa ammonium quartineri. Namun sejak tahun 2003, CDC menyatakan bahwa metode disinfeksi yang berbasis teknologi lebih baru seperti iradiasi UV-C (ultra violet-C), kabut ozon (stabilized ozon mist), hidrogen peroksida yang diuapkan untuk dekontaminasi ruang, dapat menjadi salah satu solusi disinfeksi ruangan akibat SARS-CoV-2 walaupun masih memerlukan 
penelitian lanjut. Ozon nanobubble water dilaporkan bahwa pada di Jepang, Nara Medical University, secara efektif untuk eradikasi virus SARS-CoV-2, oleh karena itu dapat menjadi salah satu pilihan untuk proses disinfeksi ruangan dengan keamanan yang tinggi (Nara University, 2020).

Jenis UV dapat dibagi menjadi UV-A, UV-B dan UV-C. Sinar UV-C sangat efektif dalam membunuh berbagai virus dengan cara dimerisasi molekul pyrimidine dari DNA atau RNA. Molekul pyrimidine ini terutama thymine (yang hanya ditemukan dalam DNA) yang menghasilkan dimer cyclobutane. Saat thymine mengalami penggabungan molekul, asam nukleat gen akan terhambat replikasinya, sehingga jika replikasi terjadi, maka akan menghasilkan defek yang letal untuk mikroorganisme tersebut. Paparan UVC menyebabkan inaktivasi parsial dalam waktu 1 menit paparan, yang semakin meningkat efektivitasnya dalam watu 6 menit paparan, sehingga jumlah virus (viral load) berkurang hingga 400 kali lipat. Setelah 15 menit, virus menjadi seluruhnya mati $(<1.0 T C I D 50(\log 10)$ per $\mathrm{mL}$, sedangkan UV-A tidak berefek apapun terhadap virus selama lebih dari 15 menit (Darnell dkk, 2004). Efektivitas virusidal dari UV-C hanya pada permukaan yang terpapar dengan sinar tersebut. Penggunaan UV-C perlu hati-hati karena dapat menimbulkan peningkatan suhu sekitar lampu UV-C tersebut sehingga menjadi lebih panas. Kondisi ini mungkin dapat diatasi dengan penggunaan AC (pendingin udara). Sinar UV-C juga sangat berbahaya jika terpapar ke sel tubuh manusia, sehingga operator wajib keluar selama paparan sinar dijalankan. Penggunaan simulasi sinar matahari secara in vitro juga efektif dalam membunuh virus SARS-CoV-2 dalam waktu 6,8-14,3 menit dengan panjang gelombang UV-B sebesar 0,3-1,6 W/m2 (Ratnesar-Shumate dkk, 2020). 


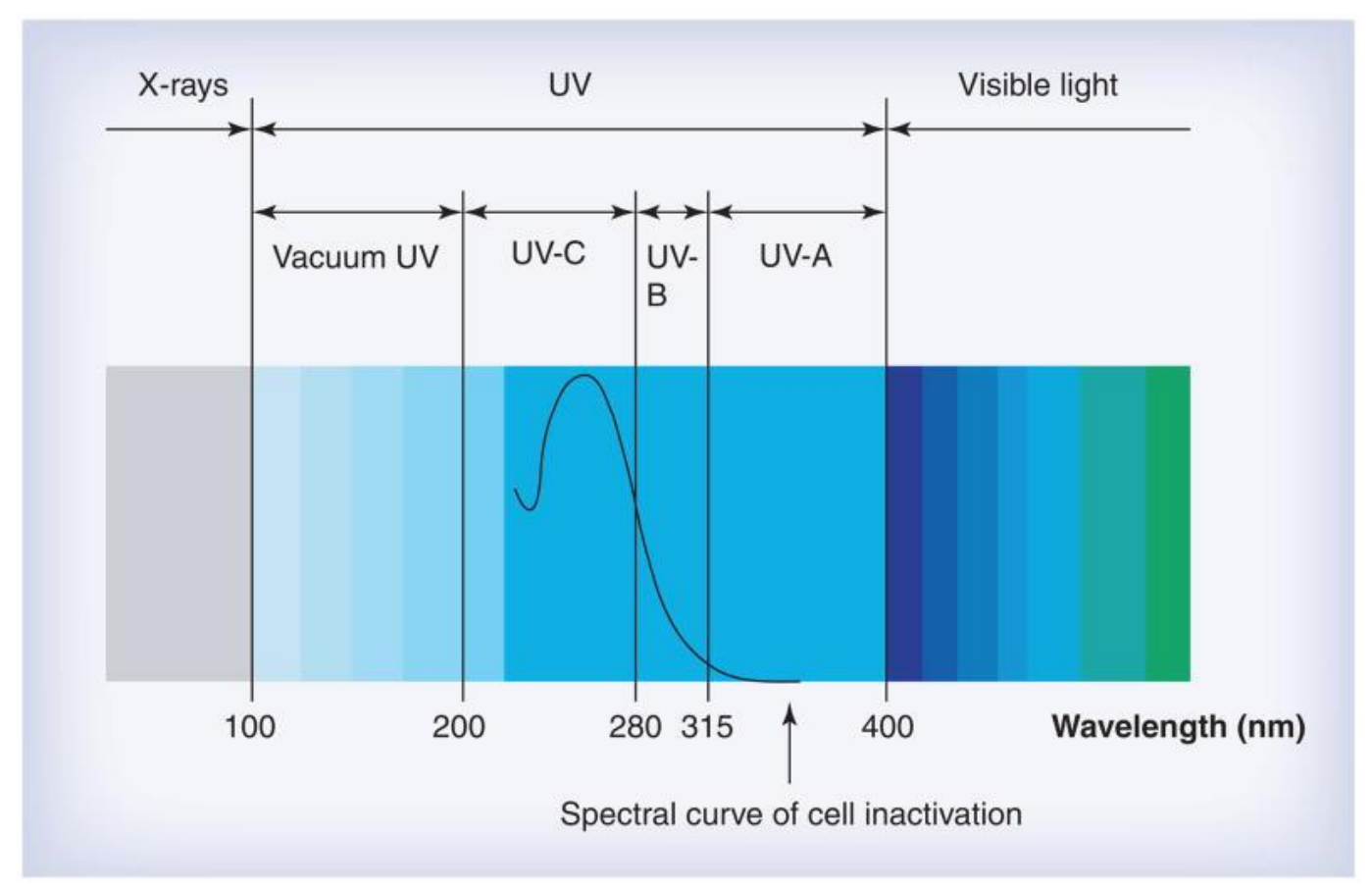

Gambar 24. Spektrum cahaya ultraviolet. (Dai dkk, 2012) 
Kontrol pembuangan limbah alat-alat kedokteran gigi disposable, terutama jarum suntik atau benda tajam lainnya semua dibuang dalam wadah khusus infeksius (Gambar 25) yang selanjutnya dieradikasi dalam incinerator. Untuk barang infeksius lain, dapat dibuang ke wadah limbah infeksius dengan kantong plastik berwarna kuning. Perlu diperhatikan, saat membungkus kantong plastik tersebut, pastikan tertutup rapat dan tidak sobek, kemudian lakukan disinfeksi di bagian luar kantong plastik.
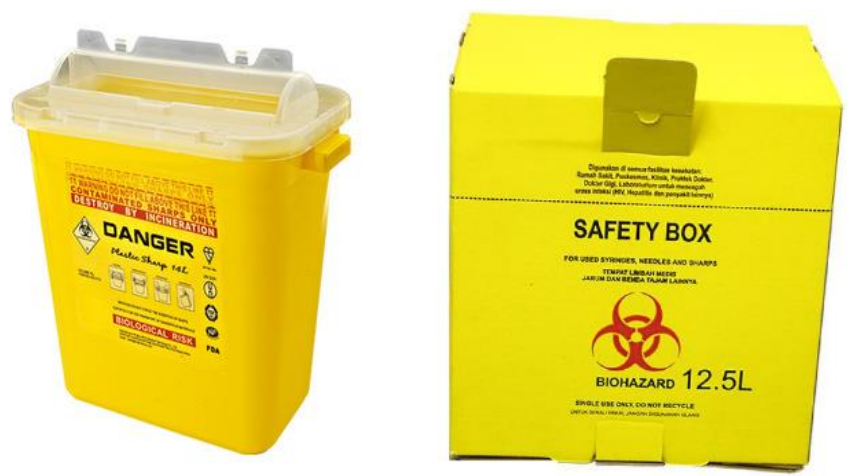

Gambar 25. Kotak tempat pembuangan limbah tajam.

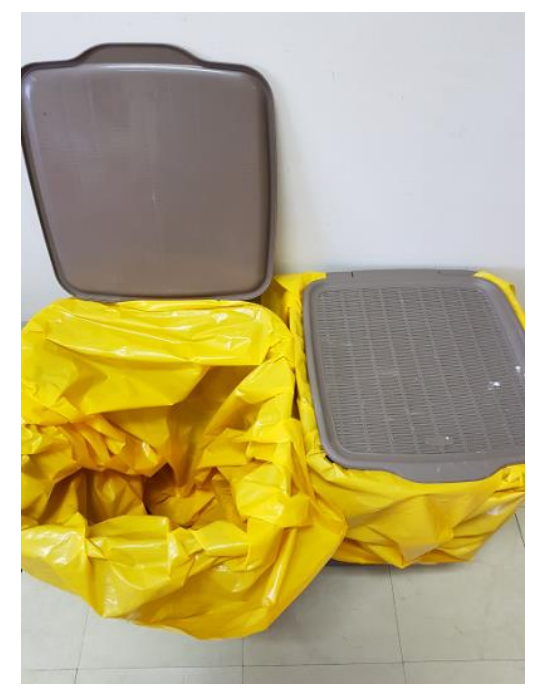

Gambar 26. Ember bertutup sebagai tempat merendam linen atau baju hazmat yang sudah digunakan. 


\section{Pembuatan Bahan Disinfeksi}

Komposisi yang disarankan dari formulasi berbasis alkohol untuk produksi lokal (rekomendasi WHO).

Dua formulasi handrub berbasis alkohol berikut ini direkomendasikan oleh WHO untuk keperluan fasilitas klinik dengan produksi lokal atau maksimum 50 liter.

\section{Formulasi I}

Untuk menghasilkan konsentrasi akhir etanol $80 \% \mathrm{v} / \mathrm{v}$, gliserol 1,45\% v/v, hidrogen peroksida $0,125 \% \mathrm{v} / \mathrm{v}$.

Tuang ke dalam wadah ukuran $1000 \mathrm{ml}$ :

a) etanol $96 \%$ sebanyak $833,3 \mathrm{ml}$

b) hidrogen peroksida $3 \%$ sebanyak $41,7 \mathrm{ml}$

c) gliserol $98 \%$ sebanyak $14,5 \mathrm{ml}$

Isi wadah hingga $1000 \mathrm{ml}$ dengan air suling atau air rebus yang sudah dingin dan kocok wadah dengan perlahan untuk mencampur isinya.

\section{Formulasi II}

Untuk menghasilkan konsentrasi akhir isopropil alkohol 75\% v/v, gliserol 1,45\% $\mathrm{v} / \mathrm{v}$, hidrogen peroksida $0,125 \% \mathrm{v} / \mathrm{v}$ :

Tuang ke dalam wadah ukuran $1000 \mathrm{ml}$ :

a) isopropil alkohol (dengan kemurnian $99,8 \%$ ) sebanyak $751,5 \mathrm{ml}$

b) hidrogen peroksida $3 \%$ sebanyak $41,7 \mathrm{ml}$

c) gliserol $98 \%$ sebanyak $14,5 \mathrm{ml}$

Isi wadah hingga $1000 \mathrm{ml}$ dengan air suling atau air rebus yang sudah dingin dan kocok wadah dengan perlahan untuk mencampur isinya. 


\section{SUMMARY BOX}

Disinfeksi alat kedokteran gigi:

1. Kategori critical item: instrumen bedah, implan, dan probe ultrasonik (skeler, handpiece, bur, probe, alat diagnostik dental): uap panas, alkohol, glutaraldehyde $\geq 2,4 \%$, glutaraldehyde $0,95 \%$ dengan fenol/phenate $1,64 \%$, stabilized hidrogen peroksida $\left(\mathrm{H}_{2} \mathrm{O}_{2}\right) 7,5 \%$, hidrogen peroksida $\left(\mathrm{H}_{2} \mathrm{O}_{2}\right) 7,35 \%$ dengan asam perasetat $0,23 \%$, dan asam perasetat $0,08 \%$ dengan hidrogen peroksida $\left(\mathrm{H}_{2} \mathrm{O}_{2}\right) \mathbf{1 , 0} \%$.

2. Kategori semi critical item: alat anestesi : glutaraldehyde, hidrogen peroksida, dan asam perasetat.

3. Kategori non critical item: manset pengukur tekanan darah, kruk dan komputer: detergen dengan air atau alkohol

Metode disinfeksi

1. Alat kedokteran gigi yang sudah dipakai: air dan detergen atau sodium hipoklorit $5 \%$ dengan perbandingan 1:100 (konsentrasi final sebesar $0.05 \%$ ) selama 1 menit. Untuk barang dengan permukaan yang kecil, dapat dibersihkan menggunakan etanol $70 \%$ atau detergen dan air selama 10 menit.

2. Handpiece tahan panas: autoklaf, uap kimia, panas kering. Handpiece tidak tahan panas: alkohol $70 \%$ atau hidrogen peroksida $1 \%$.

3. Cetakan gigi atau rahang: sodium hipoklorit $2,5 \%$. Protesa yang sedang progress atau reparasi GT: povidon iodin $1 \%$, atau hidrogen peroksida $1 \%$, atau klorin dioksida 2,5\%.

4. Baju: jika dipakai ulang: air dan detergen (direndam 30 menit).

5. Masker N95 : UV-C 1 menit, uap panas $70^{\circ} \mathrm{C} 10$ menit, dipapar sinar matahari 30 menit.

6. Kacamata/face shield: kain lap yang dibasahi alkohol $70 \%$.

7. Sepatu boot: kain lap yang dibasahi alkohol $70 \%$.

8. Dental unit, sofa, pintu, handle pintu, meja dan lainnya: kain lap dengan alkohol $70 \%$.

9. Lantai ruang praktik dan lainnya: benzalkonium klorida $2 \%$ (karbol).

10. Ruangan: UV-C, ozon mist (ozone nanobubble water). 


\section{BAB V \\ SKRINING DAN PENGATURAN PASIEN}

Skrining pasien saat pasien masuk ke klinik, dengan melakukan evaluasi kondisinya dari penampilan apakah memiliki gambaran seperti adanya peningkatan frekuensi batuk/bersin, pernapasan dan sebagainya. Penampilan klinis yang tampak dari luar, tidak menjamin pasien tersebut terinfeksi virus, namun saat skrining perlu dilakukan pencatatan tanda-tanda klinis yang dimiliki pasien.

\section{A. Alat Pendukung}

Dalam melakukan skrining pasien di tempat praktik, beberapa fasilitas pendukung juga dapat membantu dalam deteksi pasien COVID-19 yang memiliki gejala demam. Alat pendukung ini antara lain thermal gun atau bahkan kamera pemindai termal (thermal scanner camera).

A

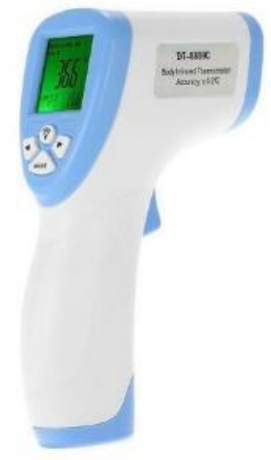

B

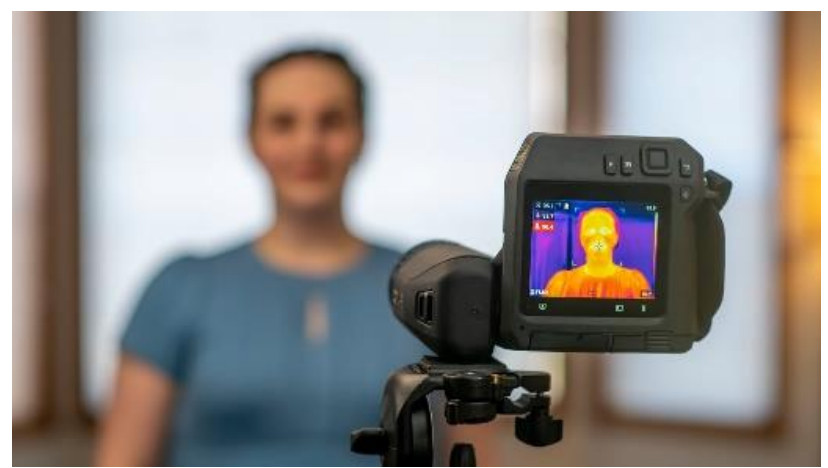

Gambar 27. A. Thermal gun. B. Kamera pemindai termal.

Efektivitas thermal gun atau termometer non-kontak telah banyak dilaporkan dalam berbagai jurnal, tetapi pada tahun 2014, Canadian Agency for Drugs and Technologies in Health menyatakan bahwa dari 6 penelitian non-radomized dan dua sistematik review mengenai penggunaan thermal gun tersebut dibandingkan dengan alat pengukur suhu tubuh melalui telinga. Diketahui bahwa penggunaan thermal gun ini masih tetap dapat disarankan untuk digunakan namun keakuratannya masih lebih kecil dibandingkan pengukur suhu lewat telinga. Penggunaan thermal gun, juga perlu diperhatikan kekuatan battery, karena dapat mempengaruhi keakuratan dari alat tersebut. Kalibrasi sebaiknya dilakukan jika sudah ada tanda nilai yang tidak akurat dari 
alat. Penggunaan kamera pemindai termal yang banyak digunakan di institusi pemerintah dan bandara, juga dapat mendeteksi suhu tubuh lebih cepat dibandingkan thermal gun. (Canadian Agency for Drugs and Technologies in Health, 2014)

\section{B. Tanda dan Gejala Infeksi SARS-CoV-2}

Pada bulan Maret 2020, WHO telah mengeluarkan formulir status pasien COVID19 , yang berisi mengenai berbagai tanda dan gejala yang dapat berhubungan dengan penyakit tersebut (Tabel 7). Berdasarkan hasil meta analisis yang dilakukan pada 43 pustaka dari 3600 pasien COVID-19, banyak gejala yang dapat timbul pada pasien tersebut. Enam gejala klinis yang paling mum ditemukan adalah (Fu dkk, 2020):

1) Demam (83,3\%),

2) Batuk (60,3\%),

3) Fatigue (38\%),

4) Mialgia (28,5\%),

5) Peningkatan produksi sputum (26,9\%),

6) Napas cepat-pendek (24,9\%).

Tabel 7. Tanda dan gejala COVID-19 menurut WHO Maret 2020.

\begin{tabular}{ll}
\hline Riwayat demam & Lower chest wall indrawing \\
Batuk & Sakit kepala \\
- Dengan sputum & \\
- Dengan haemoptisis & \\
Sakit tenggorokkan & Gangguan kesadaran/confussion \\
Rhinorrhea (pilek mengalir) & Kejang \\
Wheezing (napas berbunyi) & Sakit perut \\
Sakit di dada & Muntah/nausea \\
Mialgia (sakit pada otot) & Diarhea \\
Arthralgia (sakit pada sendi) & Konjungtivitis \\
Fatigue/malaise (kelelahan, lemas) & Kemerahan kulit \\
Napas pendek & Ulser kulit \\
Tidak mampu berjalan & Limfadenopati \\
Hemorhagik (perdarahan) & \\
\hline
\end{tabular}

Kemenkes telah mengeluarkan pedoman klasifikasi gejala COVID-19. Dalam klasifikasi ini, dapat ditentukan tindakan apa yang perlu dilakukan bagi pasien tersebut (Tabel 8). Disamping itu, kemenkes juga telah membuat alur tindakan yang perlu dilakukan jika ditemukan pasien COVID-19. Alur ini merupakan modifikasi dari WHO. 
Tabel 8. Klasifikasi gejala infeksi COVID-19 (Kemenkes 27 Maret 2020).

\begin{tabular}{|c|c|c|}
\hline Gejala Ringan & Gejala Sedang & Gejala Berat \\
\hline $\begin{array}{l}\text { - } \text { Demam }>38^{\circ} \mathrm{C} \\
\text { - } \text { Batuk } \\
\text { - Nyeri } \\
\text { tenggorokan } \\
\text { - Hidung tersumbat } \\
\text { - } \text { Malaise } \\
\text { - (tanpa } \\
\text { - } \text { pneumonia, } \\
\text { - tanpa } \\
\text { - komorbid) }\end{array}$ & $\begin{array}{l}\text { - Demam }>38^{\circ} \mathrm{C} \\
\text { - Sesak napas, batuk } \\
\text { menetap dan sakit } \\
\text { tenggorokan. } \\
\text { - Pada anak: batuk dan } \\
\text { takipneu (frekuensi napas } \\
\text { berlebihan dan dangkal) } \\
\text { - Anak dengan pneumonia } \\
\text { ringan mengalami batuk } \\
\text { atau kesulitan bernapas + } \\
\text { napas cepat: } \\
\text { frekuensi napas: } \\
<2 \text { bulan, } \geq 60 x / \text { menit; } \\
2-11 \text { bulan, } \geq 50 x / \text { menit; } \\
\text { 1-5 tahun, } \geq 40 x / \text { menit dan } \\
\text { tidak ada tanda pneumonia } \\
\text { berat. }\end{array}$ & $\begin{array}{l}\text { - Demam }>38^{\circ} \mathrm{C} \text { yang menetap } \\
\text { (dengan menggunakan obat } \\
\text { antipiretik, akan kembali } \\
\text { demam) } \\
\text { - ISPA berat/pneumonia berat } \\
\text { Pasien remaja atau dewasa } \\
\text { dengan demam atau dalam } \\
\text { pengawasan infeksi saluran } \\
\text { napas, ditambah satu dari: } \\
\text { frekuensi napas >30 x/menit, } \\
\text { pernapasan berat, atau saturasi } \\
\text { oksigen (SpO2) <90\% pada udara } \\
\text { kamar. } \\
\text { Pasien anak dengan batuk atau } \\
\text { kesulitan bernapas, ditambah } \\
\text { setidaknya satu dari berikut ini: } \\
\text { - sianosis sentral atau SpO2 } \\
\text { <90\%; } \\
\text { distres pernapasan berat } \\
\text { (seperti mendengkur, tarikan } \\
\text { dinding dada yang berat); } \\
\text { tanda pneumonia berat: } \\
\text { ketidakmampuan menyusui } \\
\text { atau minum, letargi atau } \\
\text { penurunan kesadaran, atau } \\
\text { kejang. } \\
\text { Dalam pemeriksanan darah: } \\
\text { deukopenia, peningkatan } \\
\text { dan peningkatan limfosit atipik }\end{array}$ \\
\hline Isolasi diri di ru & Rawat di RS Darurat & Rawat di RS Rujukan \\
\hline
\end{tabular}




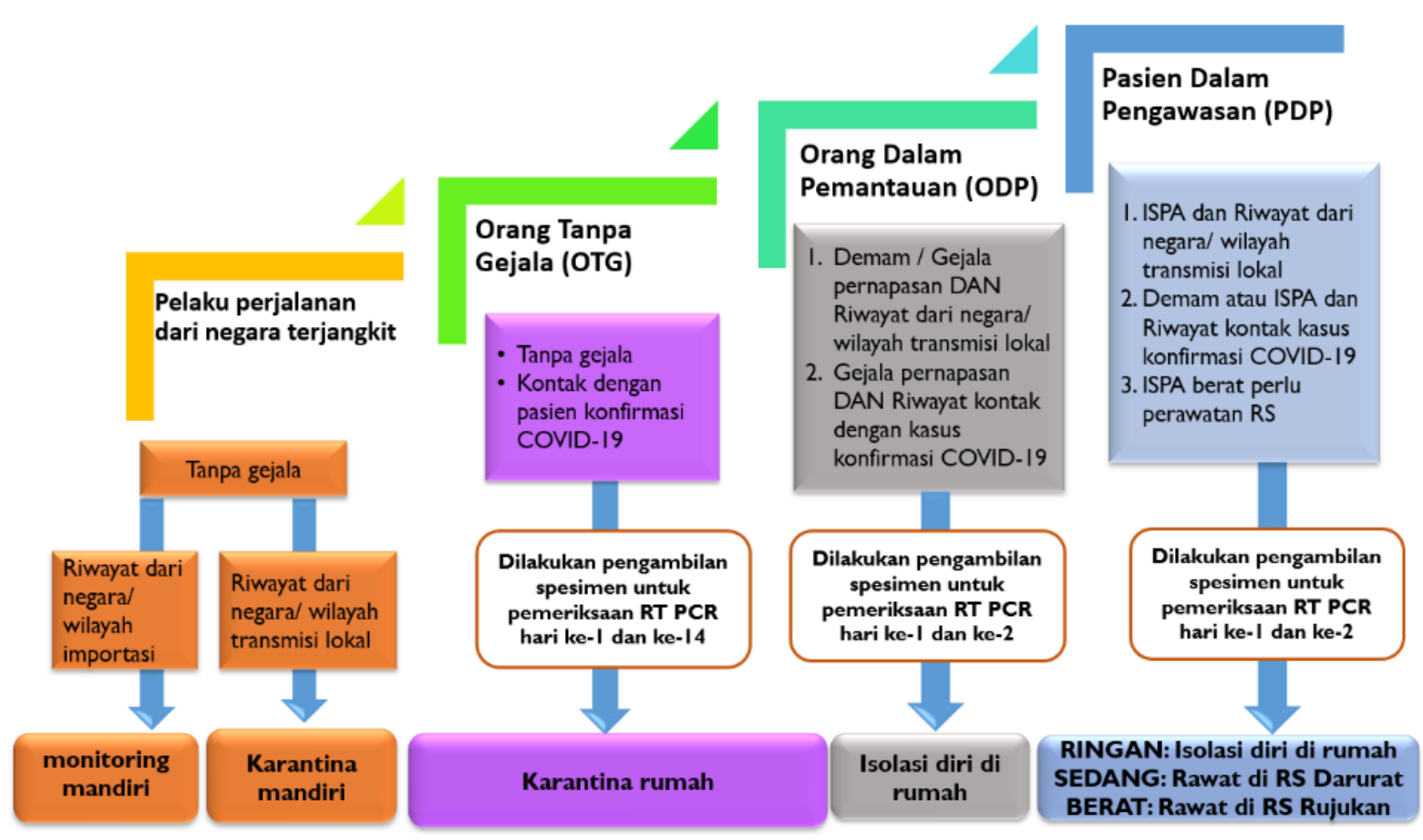

Gambar 28. Alur diagram deteksi dan respon berdasarkan kriteria kasus COVID-19.

(Kemenkes 27 Maret 2020).

\section{Pemeriksaan Laboratorium}

Berdasarkan hasil meta analisis Fu dkk (2020), tanda panel hasil laboratorik sebagai penanda infeksi adalah peningkatan $C$-reactive protein $(68,6 \%)$, penurunan jumlah limfosit $(57,4 \%)$ dan peningkatan lactate dehydrogenase $(51,6 \%)$. 


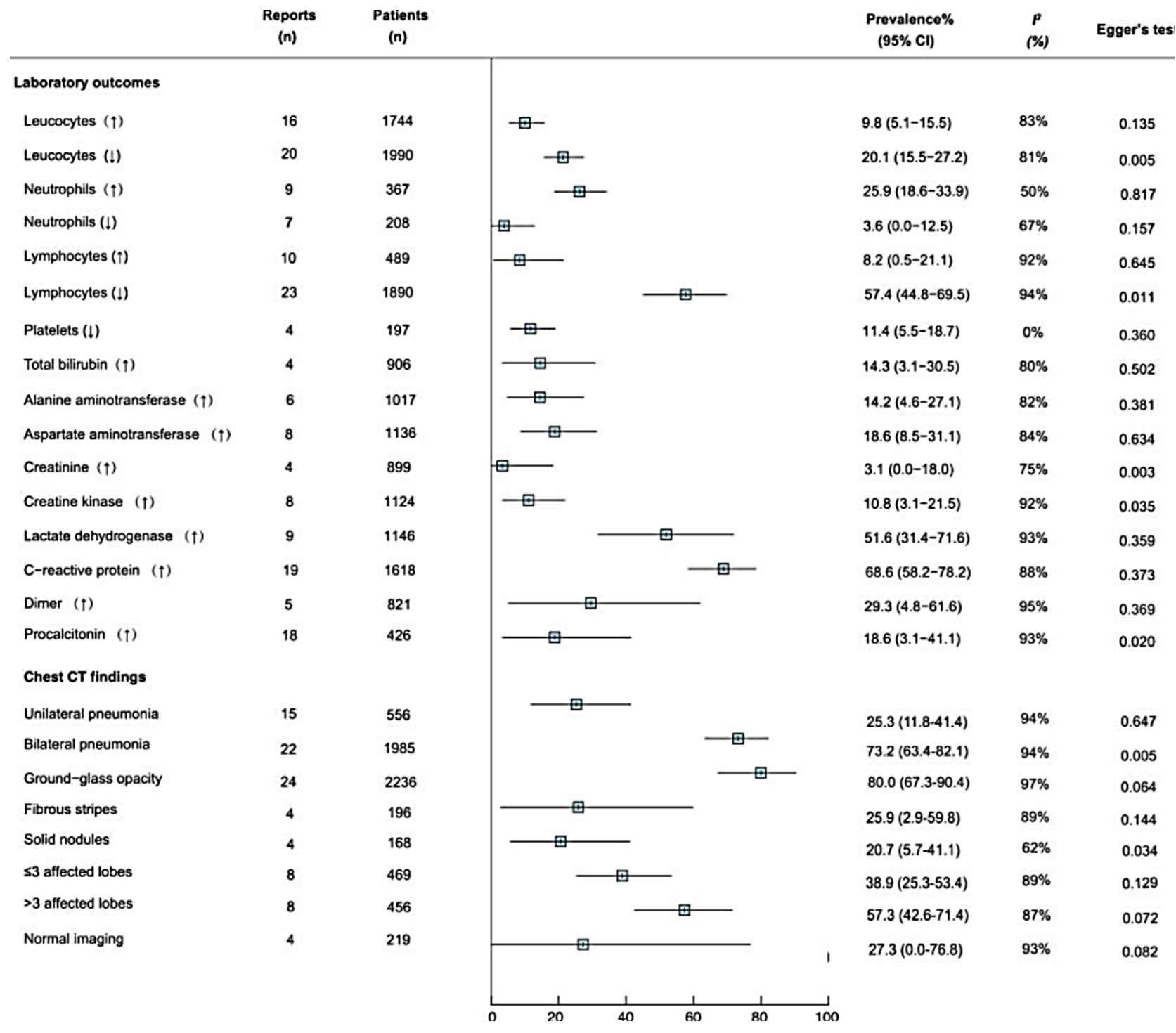

Gambar 29. Forest plot panel hasil laboratorik dari pasien COVID-19. (Fu dkk, 2020)

\section{Pemeriksaan Rapid Test}

Banyak jenis rapid test yang telah beredar di Indonesia, namun keakuratannya masih belum diketahui seluruhnya. Penggunaan rapid test ini tidak menjamin seorang negatif dari infeksi virus SARS-CoV-2. Rapid test ini bertujuan mendeteksi antibodi immunoglobulin $M(\operatorname{IgM})$ dan immunoglobulin $G(\operatorname{IgG})$ dari infeksi coronavirus, sehingga dalam deteksinya masih kurang akurat. Keakuratan dari rapid test ini juga bergantung dari jenis genetik dari virus tersebut. Dalam bab 1 tentang patogenesis, telah dijelaskan mengenai waktu fisiologis kapan terbentuknya IgM dan IgG. Rapid test ini hanya untuk mengetahui perjalanan penyakit, sedangkan Swab PCR untuk memastikan diagnosis covid. Berikut contoh dari rapid test yang beredar di Indonesia. 


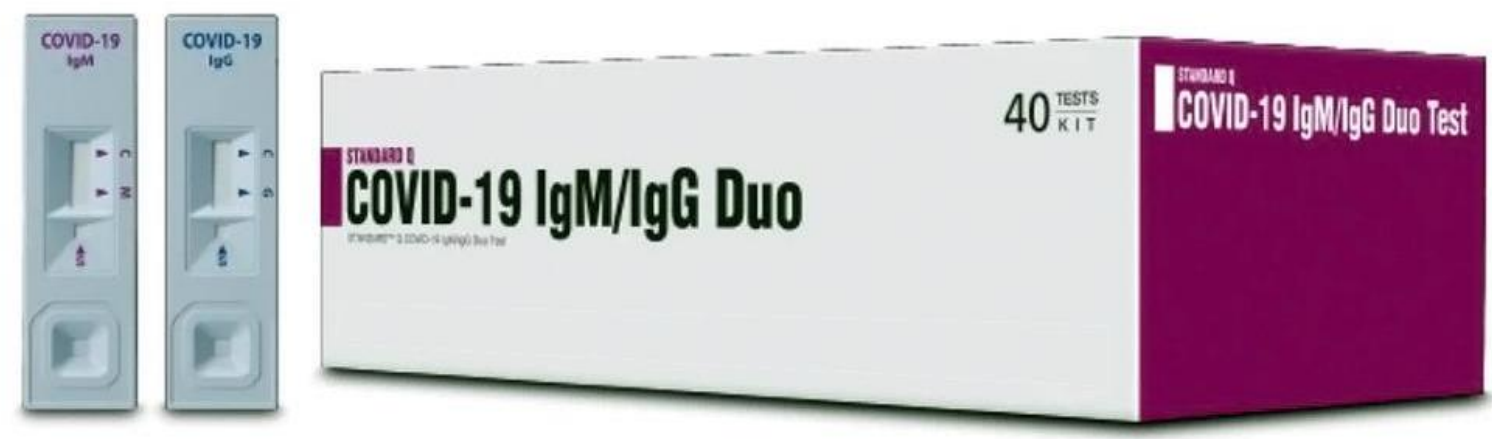

Gambar 30. Salah satu tes rapid yang di gunakan di Indonesia.

\section{E. Pengaturan Pasien}

Tempat praktik dokter gigi sebaiknya diberikan signage (tanda khusus) yang dapat dipahami dengan baik untuk selalu menjaga jarak antar pasien (lihat bab 2). Signage yang diperlukan adalah

1) Signage agar pasien tetap menggunakan masker dan melakukan cuci tangan menggunakan air sabun (di wastafel yang tersedia) atau hand sanitizer yang telah disediakan sebelum pasien duduk di ruang tunggu.

2) Signage agar pasien mendaftar terlebih dahulu dan diukur suhu tubuhnya (Jika tersedia meja pendaftaran pasien)

3) Signage tempat duduk juga perlu dipasang agar ada jarak minimal $1 \mathrm{~m}$ antar pasien

Dahulu saat awal era pandemik COVID-19, ada beberapa formulir yang telah dibuat dan digunakan untuk mengetahui seseorang berisiko terinfeksi virus SARS-CoV2, namun seiring dengan penyebaran hingga mencapai lebih dari 200 negara, maka penggunaan formulir ini menjadi kurang efektif. Terlebih lagi, gejala klinis yang muncul akhir-akhir ini semakin ringan atau bahkan tidak ada gejala. Menurut Gao dkk (2020), insidensi pasien asimtomatik COVID-19 sebesar 1,6\% - 56,5\% dari 5 negara. WHO telah menerbitkan formulir yang berisi gejala-gejala yang mungkin ditemukan pada infeksi SARS-CoV-2. Gejala tersebut dapat dilihat pada tabel 7 di bab ini.

Pengaturan pasien yang perlu diperhatikan antara lain:

1) Jadwal kedatangan pasien sebaiknya diatur terlebih dahulu agar okupansi ruangan tidak melebihi $50 \%$.

2) Sebelum masuk dalam ruang tunggu, pasien wajib tetap menggunakan masker dan melakukan cuci tangan menggunakan air sabun atau hand sanitizer yang telah disediakan. 
3) Setiap pasien yang masuk, sebaiknya dilakukan pengukuran suhu tubuh baik menggunakan thermal gun atau kamera pemindai termal (Gambar 27).

4) Dalam ruang tunggu pasien, sebaiknya diberi jarak antar pasien minimal 1 meter guna mencegah kemungkinan terjadinya penyebaran infeksi SARS-CoV-2.

5) Untuk anak-anak, sebaiknya tidak disediakan tempat bermain. Jika ada tempat bermain atau mainan atau bacaan komik, tindakan disinfeksi sebaiknya perlu dilakukan secara berkala setelah berkontak dengan anak-anak.

6) Klinik dan ruang tunggu, sofa, pintu, jendela dan barang lainnya yang mungkin disentuh oleh pasien, dapat dilakukan disinfeksi berkala setiap

7) Toilet dan wastafel yang digunakan oleh pasien juga perlu diperhatikan agar didisinfeksi secara berkala.

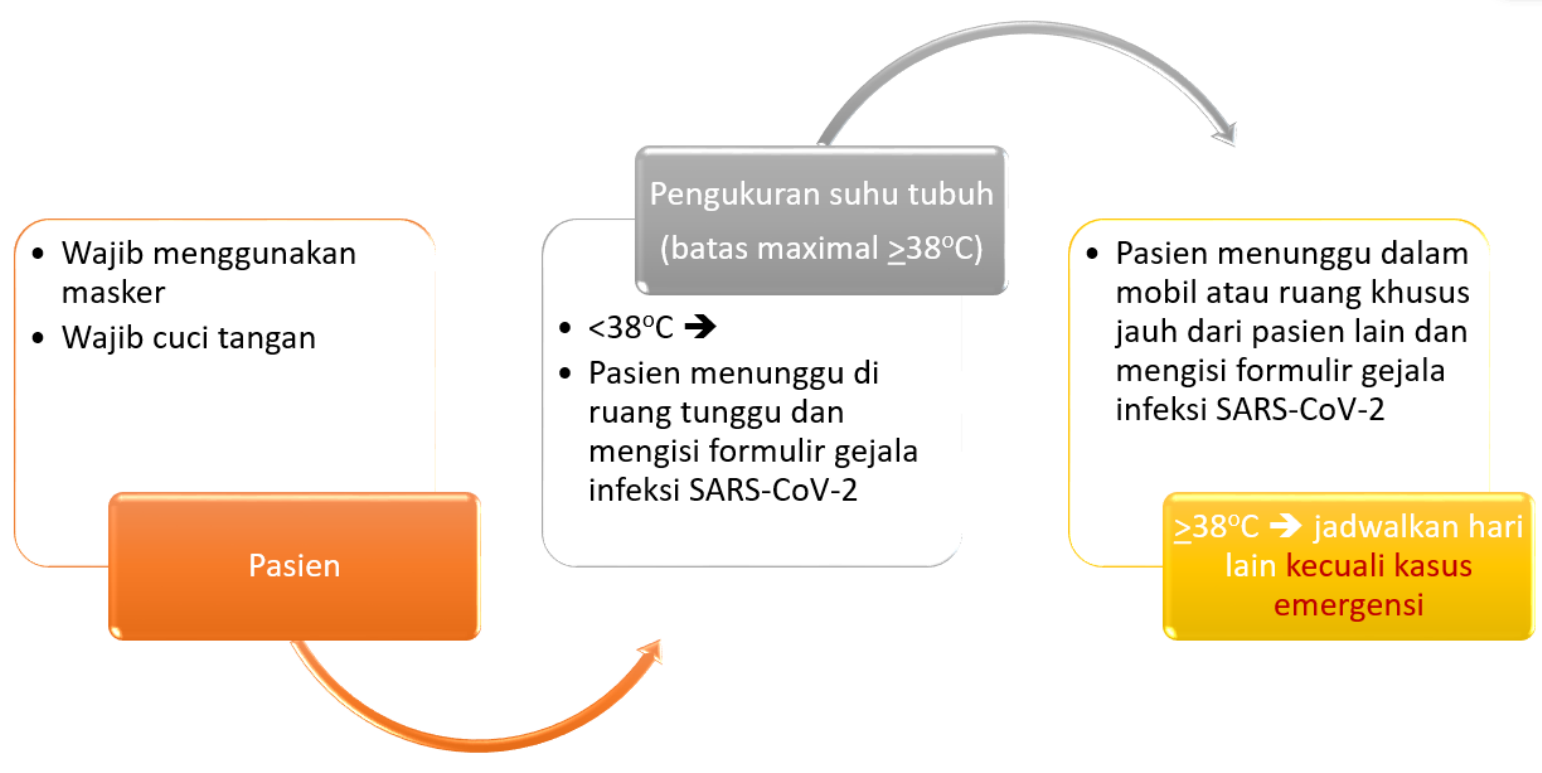

Gambar 31. Alur seleksi pasien yang masuk ke ruang praktik dokter gigi. 


\section{SUMMARYBOX}

Penggunaan alat tambahan untuk deteksi suhu tubuh (thermal gun atau kamera pemin-dai termal)

Tanda dan gejala infeksi SARS-CoV-2 yaitu

1) Demam $(83,3 \%)$,

2) Batuk $(60,3 \%)$,

3) Fatigue (38\%),

4) Mialgia (28,5\%),

5) Peningkatan produksi sputum (26,9\%),

6) Napas cepat-pendek (24,9\%).

Kemenkes telah membuat klasifikasi menjadi kategori gejala yaitu

1) Gejala ringan $\rightarrow$ isolasi mandiri

2) Gejala sedang $\rightarrow$ dirawat di RS darurat

3) Gejala berat $\rightarrow$ dirawat di RS rujukan

Untuk mendiagnosis, diperlukan pemeriksaan melalui

1) Rapid test: mendeteksi IgM dan IgG (akurasi ditentukan dari pembentukkan imunoglobulin sebagai respon sistem imun terhadap infeksi virus)

2) Swab PCR: mendeteksi RNA virus SARS-CoV-2 (akurasi ditentukan dari sejak pa-paran sampai terbentuk imunoglobulin)

3) Panel laboratorik: peningkatan CRP, penurunan jumlah limfosit, peningkatan lactate dehydrogenase

Pengaturan pasien

1) Melalui penjadwalan dan jumlah pasien (okupansi ruangan) sebesar $50 \%$.

2) Menjaga jarak antar pasien sejauh 1 meter.

3) Tetap melakukan protokol kesehatan (penggunaan masker kain, cuci tangan, ber-kumur antiseptik)

4) Pemasangan signage untuk alur pasien. 


\section{BAB VI \\ PENYAKIT KOMORBID}

Beberapa penyakit komorbid atau penyakit penyerta telah diketahui dapat memperparah gejala infeksi dari SARS-CoV-2. Jika pasien diketahui menderita penyakit komorbid ini, sebaiknya dokter gigi juga melakukan edukasi kepada pasien untuk tetap menjaga kebiasaan hidup sehat. Edukasi kebiasaan hidup sehat dibahas dalam bab 7. Hingga kini, penyakit komorbid yang telah dinyatakan oleh WHO antara lain:
1) Obesitas
2) Penyakit endokrin (diabetes melitus)
3) Chronic pulmonary obstructive disease
4) Hipertensi
5) Penyakit jantung
6) Kanker 


\section{BAB VII \\ KEBIASAAN HIDUP SEHAT}

Kebiasaan hidup sehat tentunya sangat penting dilakukan agar selalu menjaga ketahanan sistem imun terhadap segala infeksi yang mungkin timbul. Secara normal, tubuh manusia sudah memiliki mikroorganisme yang menguntungkan manusia itu sendiri (probiotik) dan ada pula yang merugikan (patogen). Namun seluruh mikroorganisme ini tidak menimbulkan infeksi pada kondisi sehat dan antar mikroorganisme juga terjadi keseimbangan satu sama lainnya.

\section{A. Physical Distancing}

WHO menganjurkan agar kita menjaga jarak setidaknya 1 meter dengan orang lain, karena saat seseorang batuk, bersin atau berbicara mereka menyemprotkan droplet/ aerosol dari hidung atau mulut mereka yang mungkin mengandung virus. Bila terlalu dekat, maka akan berisiko terhirup droplet/aerosol tersebut.

Dalam rangka menjaga kesehatan untuk dokter gigi dan perawat, maka perlu diatur physical distancing terhadap pasien, dengan cara (CDC,2019):

1) Pastikan pasien yang datang ke klinik sudah melewati proses screening, diawali dengan konsultasi secara tele-dentistry untuk memastikan pasien tidak memiliki gejala COVID-19. Jika memungkinkan, tunda perawatan gigi sampai pasien dalam kondisi sehat.

2) Meminta pasien untuk membatasi jumlah pengunjung/ keluarga yang menemani pasien pada saat perawatan gigi dan mulut di klinik, kecuali anak, lansia dan orang berkebutuhan khusus.

3) Atur jumlah maksimal orang yang di perbolehkan berada di dalam ruang praktik sesuai kepentingannya. Setidaknya 1 dokter, 1 perawat dan 1 pasien menyesuaikan ukuran ruangan praktik. Selalu perhatikan rekomendasi WHO dengan mengatur jarak antar orang setidaknya 1 meter. Pada saat di klinik, minta kepada pengunjung/keluarga yang menemani pasien agar menunggu di ruang tunggu yang telah di sediakan.

4) Semua pasien dan pendamping wajib menggunakan masker. Ketika memasuki klinik, pasien diminta untuk mengikuti prosedur skrining suhu tubuh dan gejala COVID-19.

5) Pastikan ruang tunggu klinik sudah dibuat dengan memperhatikan prosedur keamanan COVID-19 yaitu: 
a) kursi yang ditempatkan harus diberi jarak setidaknya masing-masing 1 meter.

b) benda-benda yang sering disentuh seperti mainan, majalah yang tidak dapat secara teratur di bersihkan/didisinfeksi, tidak perlu ada di ruang tunggu.

c) Batasi jumlah orang yang menunggu di ruang tunggu. Pasien dapat memilih untuk menunggu di kendaraan pribadi atau di luar klinik di mana mereka dapat dihubungi melalui ponsel ketika tiba giliran mereka untuk perawatan gigi.

6) Atur jadwal kunjungan pasien agar tidak terjadi penumpukan perawatan di waktu yang sama.

\section{B. Etiket Batuk}

Tujuan dari melakukan etiket saat bersin dan batuk adalah mencegah dan menghindarkan penyebaran suatu penyakit secara luas melalui udara bebas (droplet) dan membuat kenyamanan pada orang di sekitarnya. Droplet tersebut dapat mengandung kuman infeksius yang berpotensi menular ke orang lain disekitarnya melalui udara pernafasan. Aktivitas bersin dan batuk dapat mengandung partikel mikroorganisme yang berbahaya.

Saat ingin bersin atau batuk, sangat penting untuk mengetahui etiket. Mungkin, kebanyakan dari kita saat ingin bersin atau batuk, refleks menggunakan tangan untuk menutupinya. Namun cara ini belum sepenuhnya benar, karena virus dan bakteri dapat berpindah ke telapak tangan. Setelah itu, menular pada orang lain saat bersalaman. Oleh karena itu, etiket saat bersin dan batuk sangat perlu diperhatikan. (Kemenkes,2018)

Etiket batuk menurut WHO dan Kemenkes RI:

1) Jika terpaksa harus bepergian, saat merasa ingin bersin dan batuk segera ambil tisu untuk menutup hidung dan mulut. Segera buang tisu ke tempat sampah tertutup.

2) Bagi yang tidak membawa tisu, jangan menutup hidung dan mulut dengan telapak tangan. Namun gunakan lengan atas atau lipatan siku bagian dalam.

3) Selalu gunakan masker kain.

4) Selalu cuci tangan dengan sabun dan air mengalir.

5) Apabila tidak ada sabun, dapat menggunakan handsanitizer dengan bahan dasar alkohol.

6) Menjaga jarak (minimal 1 meter). 


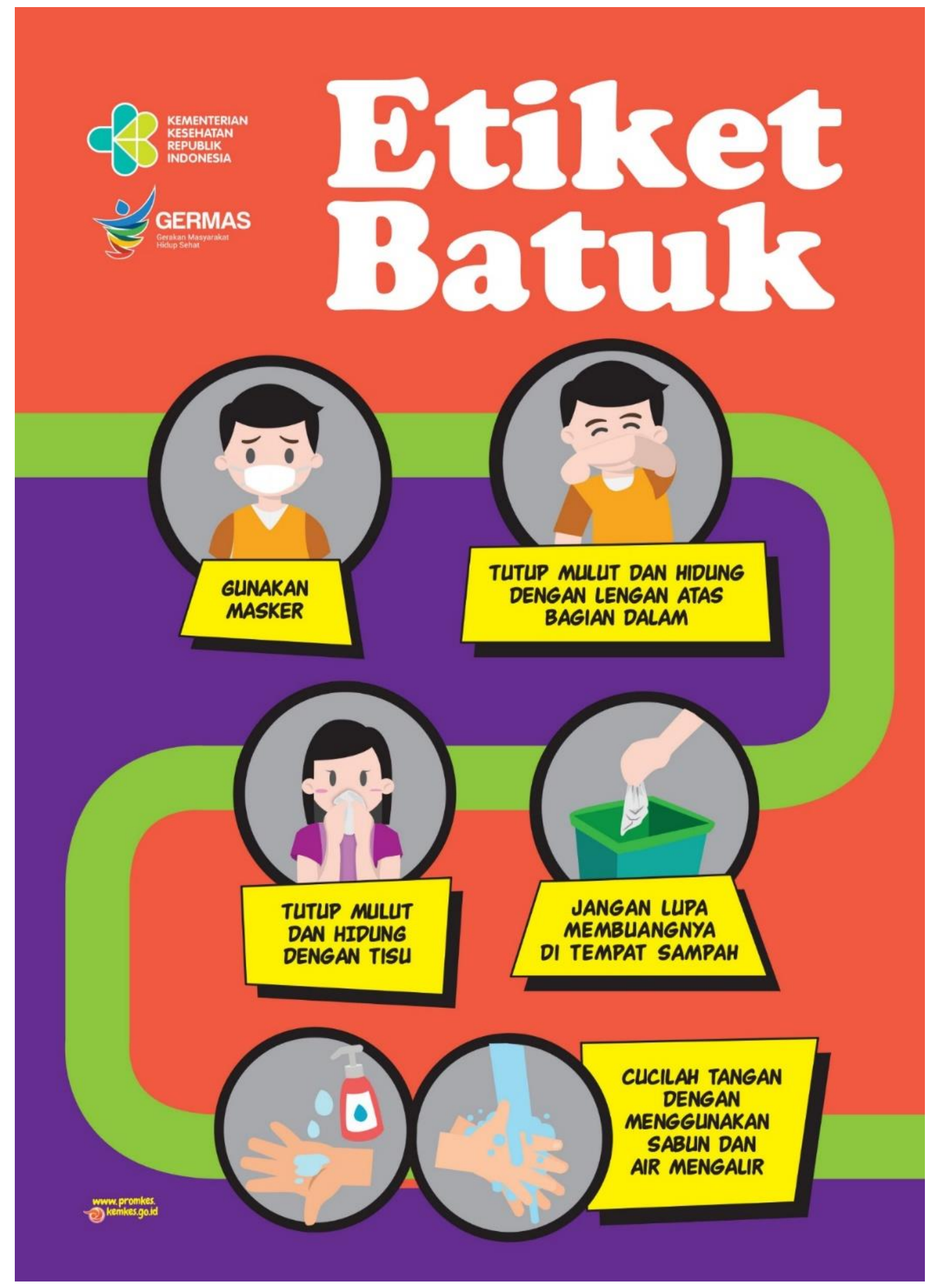

Gambar 32. Poster etiket batuk (Kemenkes). 


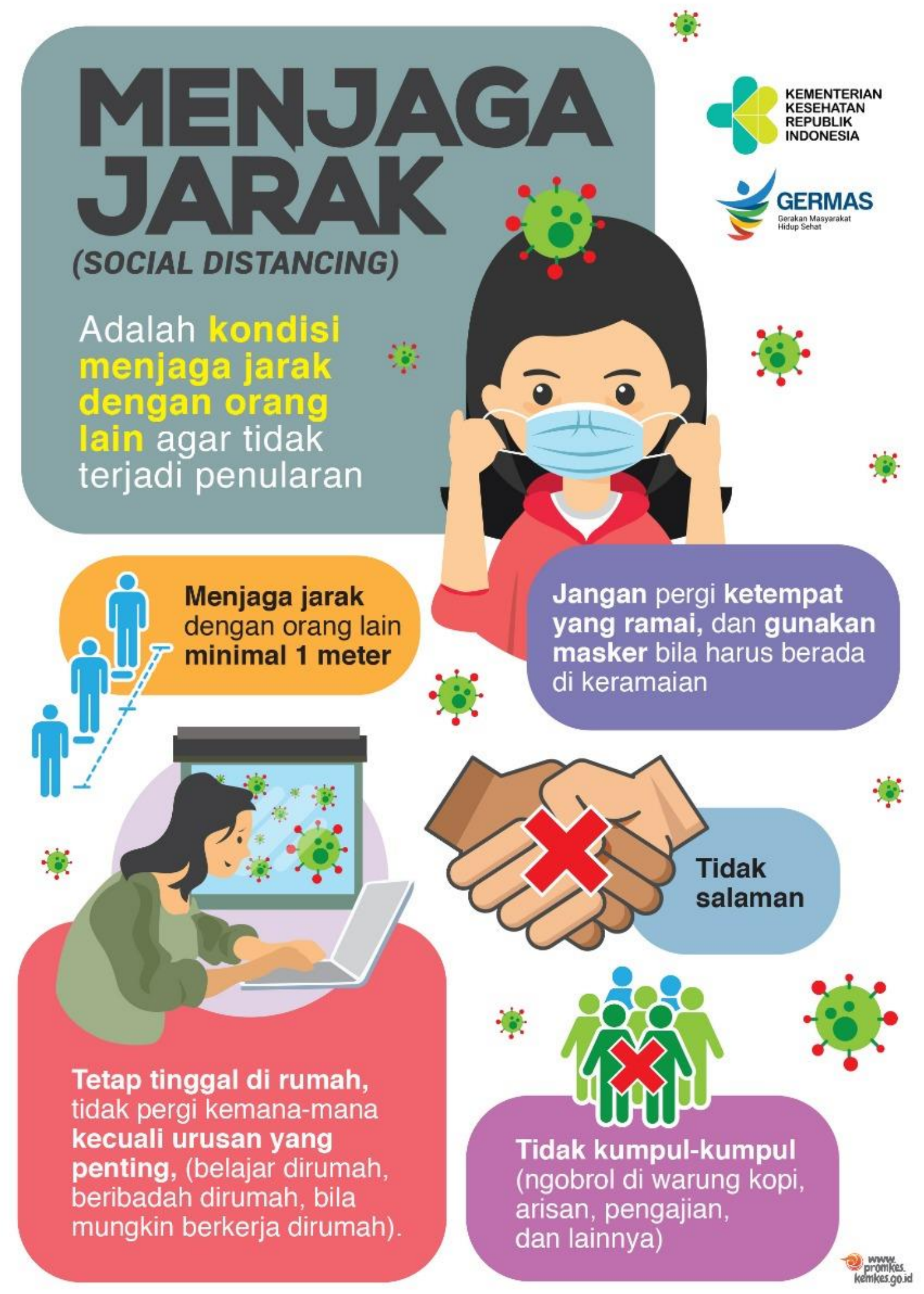

Gambar 33. Poster menjaga jarak (Kemenkes). 


\section{Kebersihan Diri dan Rumah}

Terdapat beberapa prinsip yang perlu diikuti untuk membantu mencegah COVID19, yaitu menjaga kebersihan diri/personal dan rumah dengan cara (Kemenkes, 2020):

1) Mencuci tangan lebih sering dengan sabun dan air setidaknya 60 detik atau menggunakan pembersih tangan berbasis alkohol (handsanitizer), serta mencuci muka jika memungkinkan, sesampainya rumah atau di tempat bekerja.

2) Hindari batuk atau bersin, ketika memegang makanan atau mengantarkan makanan.

3) Hindari menyentuh mata, hidung, dan mulut dengan tangan yang belum dicuci.

4) Jangan berjabat tangan.

5) Hindari interaksi fisik dengan orang yang memiliki gejala sakit influenza.

6) Tutupi mulut saat batuk dan bersin dengan lengan atas bagian dalam atau dengan tisu lalu langsung buang tisu ke tempat sampah dan segera cuci tangan.

7) Segera mengganti baju dan mandi sesampainya di rumah setelah berpergian.

8) Bersihkan dan berikan disinfektan secara berkala pada benda-benda yang sering disentuh.

9) Hindari kerumunan dan menjaga jarak dengan orang lain minimal 1 meter.

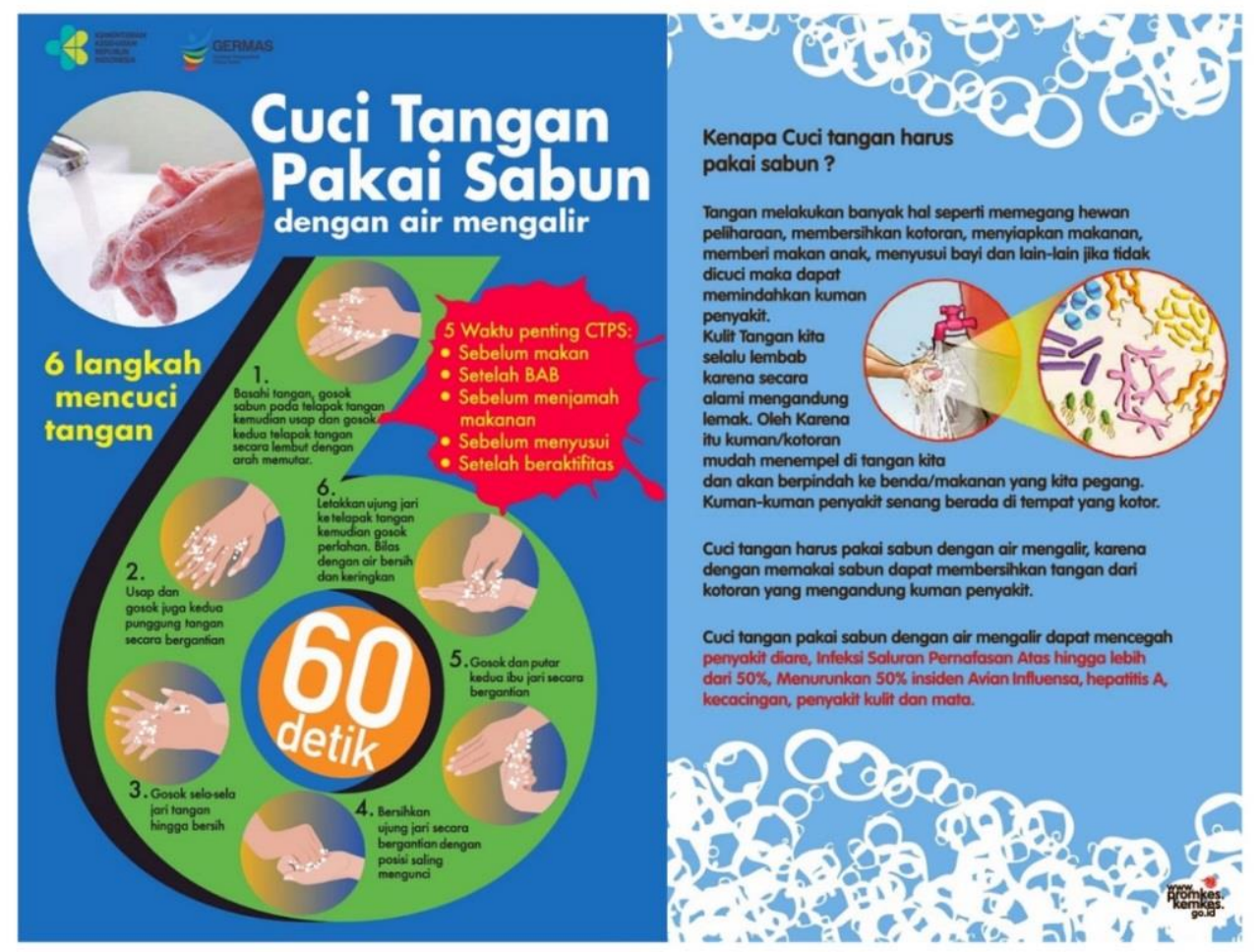

Gambar 34. Poster enam langkah mencuci tangan (Kemenkes). 


\section{Kebersihan di Ruang Praktik}

1) Selalu melakukan prosedur 6 langkah cuci tangan standar WHO dan handsanitizer, yaitu:

a) Gunakan sabun dan air mengalir jika tangan terlihat kotor secara klinis atau terkontaminasi. Cuci tangan selama 60 detik.

b) Gunakan alcohol-based hand rub (minimal konsentrasi 70\%) jika tangan tidak terlihat kotor secara klinis. Cuci tangan selama 20-30 detik.

2) Prosedur cuci tangan harus dilaksanakan pada saat (WHO 5 moment):

a) Sebelum menyentuh pasien

b) Sebelum melakukan prosedur pembersihan atau aseptik

c) Setelah terpapar cairan tubuh

d) Setelah menyentuh pasien

e) Setelah menyentuh lingkungan sekitar pasien

3) Dianjurkan untuk menggunakan rubber dam supaya mengurangi risiko penularan melalui droplet saliva akibat tekanan udara tinggi saat penggunaan handpiece.

4) Keterampilan dalam kontrol infeksi, pembuangan alat tajam dan pencegahan injuri akibat benda tajam perlu ditingkatkan.

5) Disinfeksi, pembersihan lingkungan kerja dan area klinik, penanganan alat serta pembersihan linen yang telah digunakan, telah dibahas bab 4.

6) Lakukan kontrol pembuangan limbah di ruang praktik dokter gigi dengan memperhatikan beberapa hal berikut ini : (Kemenkes,2020)

a) Penanganan limbah cair

- Limbah cair yang berasal dari mulut pasien (air kumur pasien) tidak mengalami sumbatan, yang langsung masuk dalam saluran pembuangan limbah yang berada di klinik atau rumah sakit.

- $\quad$ Air cucian alat kerja, dan air cucian linen dimasukkan langsung ke dalam lubang air limbah yang tersedia.

- Pastikan titik aliran pada semua lancar, baik di dalam maupun di luar gedung, dan lakukan pemeriksaan instalasi penyaluran dilakukan setiap hari.

b) Penanganan limbah padat

- Pastikan di ruang tunggu tersedia dua wadah limbah padat domestik yang mudah dijangkau, yaitu wadah untuk limbah padat organik dan non organik.

- Wadah tersebut dilapisi dengan kantong plastik dengan warna berbeda sehingga mudah untuk pengangkutan limbah dan pembersihan wadah. Organik adalah bahan yang mudah terurai (contoh sisa makanan, tisu, 
kertas dan lainnya), sedangkan non organik adalah bahan yang tidak mudah terurai (contoh plastik, kaleng, sterofom, kaca dan lainnya).

- Pastikan di ruang dental unit tersedia dua wadah limbah infeksius dan non infeksius. Wadah infeksius wajib dibungkus menggunakan plastik berwarna kuning untuk pembuangan masker sekali pakai, sarung tangan bekas, tisu/kain yang mengandung cairan tubuh. Sedangkan wadah non infeksius dibungkus menggunakan plastik warna selain kuning untuk pembuangan barang yang tidak berkontak dengan pasien atau cairan tubuh lainnya.

- $\quad$ Pengumpulan limbah dari wadah dilakukan bila sudah 3/4 penuh atau sekurang-kurangnya sekali dalam 24 jam. Dan untuk wadah limbah padat khusus, maka pengumpulan limbahnya dilakukan bila sudah $3 / 4$ atau sekurang-kurangnya sekali dalam 6 jam.

- Sebelum dibuang, pastikan plastik pembungkus tertutup rapat dan didisinfeksi terlebih dahulu sebelum dibawa ke incenerator.

- Petugas pengumpulan limbah harus dilengkapi dengan masker, sarung tangan, baju pelindung dan sepatu boot.

- Pengumpulan limbah dilakukan dengan langkah-langkah:

- Buka tutup tempat sampah

- Ikat kantong pelapis dengan membuat satu simpul

- Disinfeksi bagian luar kantong plastik sampah

- Setelah melakukan pengumpulan, petugas wajib membersihkan seluruh badan atau sekurang-kurangnya mencuci tangan dengan air detergen.

\section{E. Kebersihan Diri Petugas Kesehatan}

Kebersihan tangan mencakup:

1) Petugas kesehatan menerapkan "5 moment kebersihan tangan"

2) Mencuci tangan dengan sabun dan air atau menggunakan antiseptik berbasis alkohol.

3) Cuci tangan dengan sabun dan air ketika terlihat kotor.

4) Melakukan kebersihan tangan setelah membuang masker.

5) Kebersihan tangan juga diperlukan ketika menggunakan dan terutama ketika melepas APD. 
Orang dengan gejala sakit saluran pernapasan harus disarankan untuk menerapkan kebersihan/etika batuk. Selain itu mendorong kebersihan pernapasan melalui:

1) Menjaga kebersihan mulut dan hidung

2) Berkumur antiseptik

3) Penggunaan masker.

\section{F. Prosedur Pembersihan Petugas Kebersihan}

Prosedur pembersihan dan disinfeksi lingkungan harus diikuti dengan benar dan konsisten. Petugas kebersihan perlu diedukasi dan dilindungi dari infeksi COVID-19 dan petugas kebersihan harus memastikan bahwa permukaan lingkungan dibersihkan secara teratur selama periode observasi. Disinfeksi yang digunakan, dapat dilihat pada bab 4. Perlu dipertimbangkan langkah-langkah untuk memastikan sampah dibuang di tempat pembuangan akhir/TPA yang terstandar, dan bukan di area terbuka yang tidak diawasi. Petugas kebersihan harus mengenakan sarung tangan sekali pakai saat membersihkan atau menangani permukaan, pakaian atau linen yang terkontaminasi oleh cairan tubuh, dan harus melakukan kebersihan tangan sebelum dan sesudah melepas sarung tangan.

\section{G. Berkumur Antiseptik}

Berkumur dengan menggunakan antiseptik atau obat kumur adalah salah satu upaya yang dapat dilakukan tenaga kesehatan khususnya dokter gigi untuk pencegahan penyebaran virus COVID-19. Pengaplikasian obat kumur juga dapat diterapkan pada pasien yang melakukan pemeriksaan atau perawatan gigi. Pada hasil penelitian ditemukan $41 \%$ pasien mempunyai transmisi nosokomial dan disimpulkan oleh WHOCDC bahwa penyebaran COVID-19 melalui droplet atau aerosol. Untuk itu praktik dokter gigi rentan tertular COVID-19 karena sangat dekat dengan sumber droplet terutama saat dokter tersebut melakukan pemeriksaan pada pasien. Hal ini disebabkan karena saliva mengandung konsentrasi tinggi COVID-19. Mengingat SARS-CoV-2 sangat rentan terhadap oksidasi sehingga mouthwash atau obat kumur yang lebih tepat digunakan adalah hydrogen perioksida atau povidone iodone. (Peng, $d k k, 2020$ )

Berkumur selama 1 menit dengan larutan antiseptik (povidon iodin 0,2\% - 1\%, hidrogen peroksida, klorin dioksida) sebelum dilakukan tindakan perawatan gigi disarankan untuk mencegah penyebaran COVID-19.(Kirk-Bayley J dkk, 2020) Hidrogen peroksida $0,5 \%$ - $1 \%$ selama 1 menit, terbukti efektif terhadap coronavirus. Untuk rongga mulut, penggunaan hidrogen peroksida 1-3\%. Dalam laporan Peng dkk (2020), disarankan penggunaan hidrogen peroksida sebagai obat kumur. (Peng, $d k k, 2020)$ 
Selain itu, povidon iodin (PVP-I) juga disarankan dipakai sebagai obat kumur, karena PVP-I merupakan suatu kompleks polimer sintetik polyviny/pyrrolidone (povidone) yang berikatan hidrogen dengan unsur iodium $\left(I_{3}\right)$. (Gottardi W,1991) Di dalam larutan air, ekuilibrium kimiawi yang terbentuk membuat hanya sedikit ion iodin yang dilepas sebagai iodin bebas $\left(\mathrm{I}_{2}\right)$.

Cara pemakaian antiseptik sebelum tindakan kedokteran gigi (Kirk-Bayley dkk, 2020):

Povidon iodin $1 \%$ dikumur di depan (rongga mulut) selama 30 detik dan selanjutnya miringkan kepala ke arah belakang sekitar $45^{\circ}$ lalu kumur selama 30 detik sehingga berbunyi ("RRRRRRR") kemudian dibuang. Total berkumur 1 menit. Setelah itu, disarankan tidak makan atau minum atau berkumur lainnya, selama 30 menit. Untuk pasien COVID-19, disarankan penggunaan sebanya 5-6 kali per hari. Untuk tenaga kesehatan yang memiliki riwayat berkontak dengan pasien yang dicurigai COVID-19, disarankan berkumur 3-4 kali per hari. Untuk obat kumur lainnya, disesuaikan dengan petunjuk dari obat tersebut.

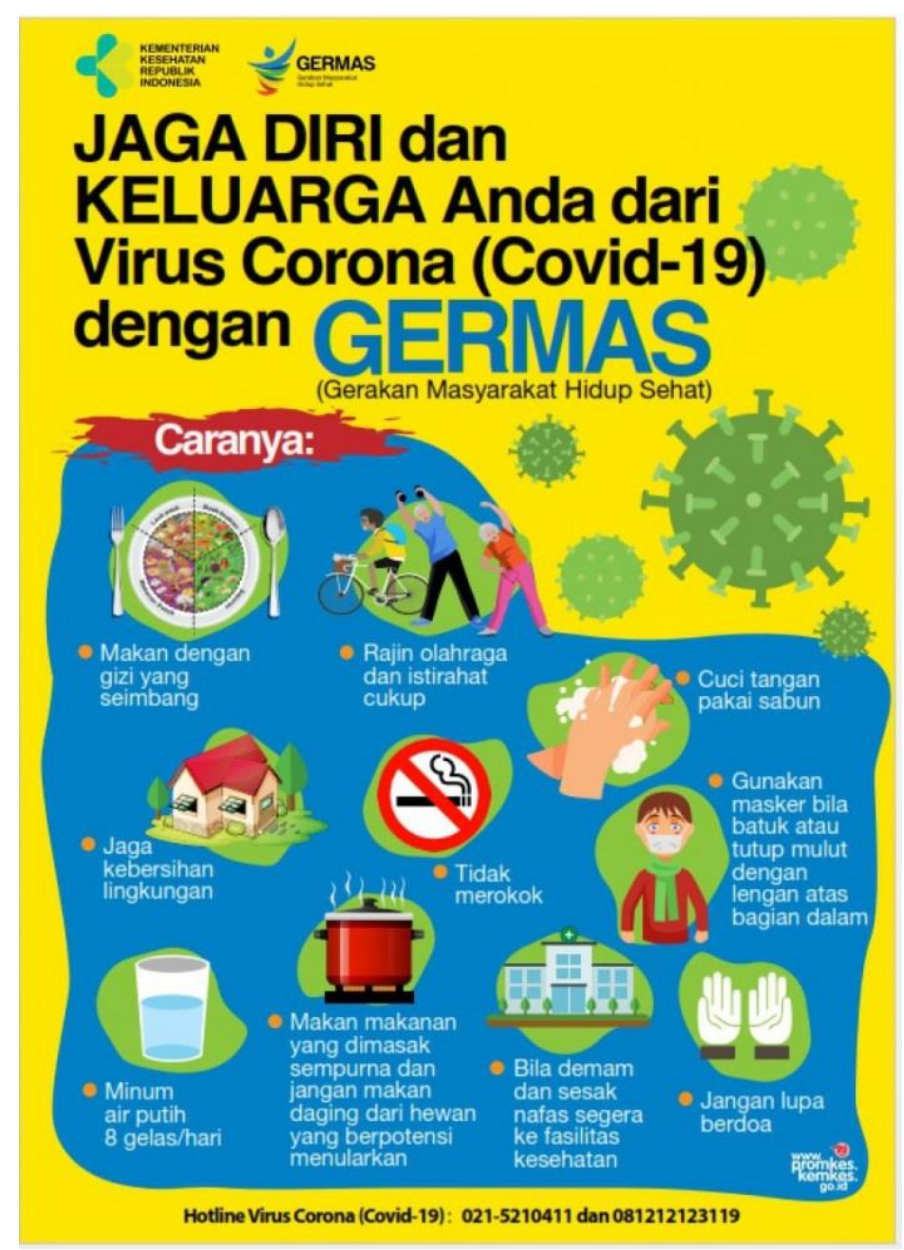

Gambar 35. Poster hidup sehat di masa era new normal (Kemenkes). 


\section{H. Konsumsi Makanan Bergizi}

Mengkonsumsi makanan yang bergizi sangat berpengaruh pada kesehatan dan keseimbangan gizi yang ada di dalam tubuh. Namun,tidak ada satupun jenis makanan yang mengandung semua jenis zat gizi yang dibutuhkan tubuh untuk menjamin pertumbuhan dan mempertahankan kesehatannya, kecuali Air Susu Ibu (ASI) untuk bayi baru lahir sampai berusia 6 bulan. Contoh: nasi merupakan sumber utama kalori, tetapi miskin vitamin dan mineral; sayuran dan buah-buahan pada umumnya kaya akan vitamin, 18 mineral dan serat, tetapi miskin kalori dan protein; ikan merupakan sumber utama protein tetapi sedikit kalori. Jadi, makan itu sebaiknya bukan sekadar kenyang, tetapi untuk memenuhi kebutuhan nutrisi dan menjaga kesehatan tubuh.

Piring sajian sebaiknya diisi dengan asupan karbohidrat, protein, vitamin, dan mineral seimbang. Hal ini dikarenakan tidak ada satupun jenis makanan yang mengandung semua jenis zat gizi yang dibutuhkan tubuh. Untuk itu, konsumsilah pangan yang beragam.

Dalam satu porsi sajian, sayur-sayuran dan buah-buahan disarankan porsinya adalah separuh bagian piring. Sementara itu, separuh bagian piring lainnya dapat diisi dengan karbohidrat dan protein. (Kemenkes, 2017)

\section{Makanan yang mengandung karbohidrat}

Makanan pokok yang mengandung karbohidrat antara lain beras, kentang, singkong, ubi jalar, jagung, talas, sagu, dan sukun. (Kemenkes, 2014)

\section{Jadikan ikan sbagai sumber protein utama}

Secara umum komposisi protein hewani pada ikan sebenarnya tidak terlalu berbeda kandungannya dengan protein hewani lainnya. Namun, ikan dikatakan lebih menyehatkan karena lemak yang terkandung di dalam ikan bukan merupakan lemak jenuh. Sebagai salah satu sumber protein hewani, ikan mengandung asam lemak tak jenuh (omega, yodium, selenium, fluorida, zat besi, magnesium, zink, taurin, serta coenzyme Q10). Selain itu, kandungan omega-3 pada ikan jauh lebih tinggi dibanding sumber protein hewani seperti daging sapi dan ayam. (Kemenkes, 2017)

\section{Konsumsi sayuran dan buah secara rutin}

Sayuran yang dianjurkan adalah sayuran hijau dan sayuran berwarna lainnya, antara lain bayam, kangkung, wortel, daun kecipir, kol dan lainnya. Selain sayuran, buah-buahan juga menunjang keseimbangan gizi dalam tubuh. Untuk itu, kombinasi sayuran serta buah-buahan sangan diperlukan untuk menyeimbangkan kandungan karbohidrat dan protein yang dikonsumsi. (Kemenkes, 2014) 


\section{Batasi konsumsi gula, garam, dan lemak serta air}

Dalam setiap sajian, masyarakat juga sebaiknya memperhatikan kandungan gula, garam dan lemak. Batasan konsumsi gula, garam, dan lemak yang disarankan Kementerian Kesehatan per orang per hari adalah: gula tidak lebih dari 50 gr (4 sendok makan); garam tidak melebihi $2000 \mathrm{mg}$ natrium/sodium atau $5 \mathrm{gr}$ (1 sendok teh), dan untuk lemak hanya $67 \mathrm{gr}$ (5 sendok makan minyak). Untuk memudahkan mengingat rumusannya adalah G4 G1 L5.

Gula merupakan salah satu sumber energi yang dibutuhkan manusia. Namun, jika berlebihan, gula dapat menyebabkan obesitas dan memicu diabetes tipe 2 . Di dalam buah-buahan segar terdapat gula alami, sehingga sebenarnya tambahan gula tidak dibutuhkan lagi.

Sementara itu, garam mengandung natrium dan sodium. Garam dalam jumlah sedikit dibutuhkan untuk mengatur kandungan air dalam tubuh. Jika berlebihan, garam dapat menyebabkan hipertensi hingga stroke. Sedangkan lemak, juga diperlukan dalam tubuh sebagai cadangan energi. Lemak berlebih dapat meningkatkan risiko penyakit jantung hingga kanker. Lemak dapat berbentuk padat dan cair (minyak). Lemak pun banyak ditemui pada makanan yang digoreng. Asupan air setiap hari minimal 2,5 L juga perlu diperhatikan agar menjaga keseimbangan homeostasis cairan tubuh serta elektrolit. (Kemenkes, 2017)

\section{Perilaku Hidup Bersih dan Sehat}

Dokter gigi memiliki peranan untuk senantiasa menjalankan dan mengkampanyekan Gerakan Masyarakat Hidup Sehat (GERMAS) melalui Pola Hidup Sehat dan Perilaku Hidup Bersih dan Sehat (PHBS).

\section{Untuk Dokter Gigi}

Selalu menerapkan Germas melalui Pola Hidup Bersih dan Sehat saat di rumah, dalam perjalanan ke dan dari tempat kerja dan selama di tempat kerja;

1) Saat perjalanan ke/dari tempat kerja

a) Pastikan anda dalam kondisi sehat, jika ada keluhan batuk, pilek, demam agar tetap tinggal di rumah.

b) Gunakan masker kain (yang dibuat dari 3 lapis kain yang berbeda jenisnya sesuai saran dari WHO), kecuali jika sedang tidak sehat.

c) Upayakan tidak menggunakan transportasi umum, jika terpaksa menggunakan transportasi umum,

- Tetap menjaga jarak dengan orang lain minimal 1 meter. 
- Upayakan tidak sering menyentuh fasilitas umum, gunakan handsanitizer.

- $\quad$ Gunakan helm sendiri.

- Upayakan membayar secara non tunai, jika terpaksa memegang uang gunakan handsanitizer sesudahnya.

- Tidak menyentuh wajah atau mengucek mata dengan tangan, gunakan tisu bersih jika terpaksa.

2) Selama di tempat kerja

a) Saat tiba, segera mencuci tangan dengan sabun dan air mengalir.

b) Gunakan siku untuk membuka pintu dan menekan tombol lift.

c) Tidak berkerumun dan menjaga jarak di lift dengan posisi saling membelakangi.

d) Bersihkan meja, kursi, dental unit serta area kerja dengan disinfektan.

e) Upayakan tidak sering menyentuh fasilitas/peralatan yang dipakai bersama di area kerja, gunakan handsanitizer.

f) Tetap menjaga jarak dengan rekan kerja dan pasien minimal 1 meter.

g) Saat mengerjakan pasien, pastikan semua peralatan yang digunakan dalam kondisi steril, dan senantiasa menggunakan standar APD yang di tentukan.

h) Usahakan aliran udara dan sinar matahari masuk ke ruang kerja.

i) Biasakan tidak berjabat tangan.

j) Tetap gunakan masker.

k) Hindari penggunaan alat pribadi secara bersama seperti alat sholat, alat makan, alat minum dan lain lain.

I) Makan makanan dengan gizi seimbang.

m) Lakukan gerakan-gerakan ringan saat setelah mengerjakan pasien. Untuk tetap memperlancar peredaran darah tubuh. (Kemenkes, 2020)

\section{Untuk dokter gigi dan pasien saat di rumah}

a) Jangan bersentuhan dengan anggota keluarga sebelum membersihkan diri (mandi, cuci rambut dan mengganti pakaian kerja).

b) Cuci pakaian dan masker dengan deterjen. Masker sekali pakai, sebelum dibuang sebaiknya dirobek terlebih dahulu dan semprot dengan disinfektan agar tidak mencemari petugas pengelola sampah.

c) Bersihkan handphone, kacamata, tas dengan disinfektan.

d) Tetap tinggal di rumah. Jika tidak ada keperluan mendesak jangan keluar rumah. Jika terpaksa harus keluar rumah, gunakan masker, hindari ke 
tempat-tempat dengan kerumunan orang banyak, selalu menjaga jarak dengan orang lain minimal 1 meter, segera selesaikan keperluan lalu pulang. Patuhi petunjuk dari pemuka agama.

e) Jaga kebersihan rumah

- Dibersihkan dan dipel 2 kali sehari.

- Optimalkan sirkulasi udara dan cahaya matahari di rumah.

- Biarkan udara pagi dan sinar matahari masuk dalam rumah.

f) Cuci tangan pakai sabun dan air mengalir. Setiap kali tangan kotor, setelah buang air besar, setelah menceboki bayi dan anak, sebelum dan sesudah makan, sebelum menyuapi.

g) Biasakan etiket batuk/bersin dengan menutup mulut dan hidung dengan lengan atas bagian dalam.

h) Gunakan masker bila batuk/pilek/demam.

i) Pisahkan jika ada anggota keluarga yang sakit.

j) Jaga jarak atau pisahkan ruangan apabila ada yang sakit, gunakan masker.

k) Tingkatkan daya tahan tubuh dengan konsumsi gizi seimbang, aktifitas fisik minimal 30 menit perhari, istirahat cukup (tidur minimal 7 jam), berjemur di pagi hari.

\section{J. Kegiatan Fisik}

Istirahat sejenak dari posisi duduk, dengan melakukan gerakan fisik intensitas ringan 3-4 menit, seperti berjalan atau meregangkan tubuh, akan membantu meringankan otot dan meningkatkan sirkulasi darah dan aktivitas otot.

Aktivitas fisik yang teratur bermanfaat bagi tubuh dan pikiran. Ini dapat mengurangi tekanan darah tinggi, membantu mengelola berat badan dan mengurangi risiko penyakit yang rentan terhadap COVID-19 seperti jantung, stroke, diabetes tipe 2, dan kanker. Bentuk kegiatan fisik yang sangat di anjurkan untuk orang dewasa dan yang lebih tua adalah berjalan kaki, baik dirumah maupun di luar rumah dengan tetap memperhatikan prosedur keamanan dan keselamatan terhadap virus penyebab COVID-19. WHO menganjurkan untuk dewasa minimal aktifitas fisik 30 menit sehari, dan untuk anak-anak 1 jam sehari. Salah satu bentuk aktifitas di rumah, adalah berjalan naik dan turun tangga, lakukan peregangan badan, menari mengikuti irama musik, mengikuti sesi olahraga secara online, bermain video games, ataupun olahraga skipping. 


\section{K. Istirahat cukup}

Istirahat yang cukup harus memenuhi syarat kuantitas dan kualitas yang baik.

Kuantitas : Tidur malam minimal 7 jam setiap hari.

Kualitas : Tidak sering terbangun saat tidur, bangun di pagi hari dengan segar, dapat tidur dengan mudah 30 menit setelah berbaring.

Pada saat bekerja, juga dianjurkan untuk memanfaatkan waktu istirahat. Dengan cara memperbaiki posisi duduk, bangun dari tempat duduk dan melakukan peregangan otot, jalan-jalan kecil untuk melancarkan sirkulasi darah.

\section{SUMMARY BOX}

Kebiasaan hidup sehat bagi pasien dan dokter gigi

1) Physical distancing di dalam ruang praktik

2) Etiket batuk

3) Kebersihan diri dan rumah

4) Kebersihan di ruang praktik dokter gigi

5) Kebersihan diri petugas kesehatan

6) Prosedur pembersihan petugas kebersihan

7) Berkumur antiseptik

8) Konsumsi makanan bergizi

9) Kegiatan fisik 


\section{BAB VIII \\ UNIT COST}

Kebutuhan akan penyesuaian praktik dokter gigi di era new normal akan membuat pengeluaran yang cukup signifikan. Bagaimana dokter gigi mengatasi dan memberitahukan kepada pasien tentang pembiayaan yang timbul merupakan tantangan yang harus dihadapi. Tentu saja sebagai dokter gigi harus tetap memperhatikan fungsi sosialnya apabila memang terdapat pasien yang membutuhkan bantuan pembiayaan tindakan praktik dokter gigi. Pada poin ini perlu sekiranya juga diberikan dasar perhitungan pembiayaan kebutuhan praktik dokter gigi. Konsep pembiayaan perlu dipahami oleh dokter gigi agar dapat memberikan penjelasan yang baik kepada pasien atau kepada pihak ketiga yang membutuhkan (BPJS dan asuransi swasta lainnya).

Pengertian tentang pembiayaan adalah pengorbanan sumber-sumber ekonomi yang sudah terjadi atau akan terjadi yang dinyatakan dalam satuan uang untuk tujuan tertentu. Pricing/ tarif menjadi produk dalam layanan praktik drg yang menggambarkan kesimbangan value/nilai layanan yang dipersepsikan oleh pasien. Dokter gigi wajib menciptakan keseimbangan yang dipersepsikan pasien tentang apa yang dikeluarkan dari kantong pasien dan apa yang didapatkan pasien dari tindakan perawatan dokter gigi. Persepsi nilai tarif harus dibuat "total get harus lebih besar dari pada total give" sehingga akan dinilai seimbang atau lebih memuaskan oleh pasien-pelanggan. Dalam panduan ini akan diberikan tata cara perhitungan yang sederhana dalam menentukan tarif pelayanan praktik dokter gigi era COVID-19.

Perhitungan tarif dimulai dari pengertian tentang jenis biaya, yaitu:

- Fixed costs (Biaya tetap): biaya yang bersifat tetap tidak dipengaruhi oleh biaya volume atau produksi. Misalnya biaya sewa tempat, renovasi dan lainnya

- Variable costs (Biaya variabel): biaya yang sifatnya variabel atau berubah menurut julah produksi. Misalnya biaya material (bahan APD), jasa medis dan lainnya

\section{A. Fixed Cost}

Biaya yang tetap sama walaupun terjadi perubahan output, dengan jumlah pasien 1 ataupun bahkan 100 pasien maka biaya unit cost yang dikeluarkan akan selalu sama. Ilustrasi untuk pembiayaan ini dapat diambil contoh, misalkan biaya renovasi ruang 
praktik yang muncul akibat perlunya pembenahan aliran sirkulasi udara. Perhitungan tarif, apabila belum terdapat data yang pasti maka dapat diterapkan asumsi perhitungan yang mendekati. Asumsi pendekatan untuk menghitung fixed cost biasanya dihitung dalam satuan waktu tahun berjalan. Sehingga apabila kita contohkan pembiayaan renovasi membutuhkan total biaya sebesar Rp. 30.000.000. Maka kita perlu menghitung asumsi kunjungan pasien perhari yang dapat diperhitungkan untuk menanggung beban pembiayaan tersebut.

Asumsi yang kita pergunakan adalah jumlah kunjungan per hari di tempat praktik kita adalah 4 pasien, maka asumsi jumlah pasien dalam satu tahun adalah
- 1 hari 4 pasien
- 1 minggu 6 hari kerja : 6 × $4=24$ (senin - sabtu buka praktik)
- 1 bulan : $24 \times 4=96$
- 1 tahun : $96 \times 12=1.152$
- 2 tahun : $1152 \times 2=2304$

Dengan beban pembiayaan renovasi sebesar 30 juta tersebut dan kita berasumsi bahwa uang tersebut di asumsikan untuk jangka waktu 2 tahun maka perhitungan unit cost tarif renovasi tersebut adalah:

Rp. 30.000 .000 / 2304 (jumlah pasien dalam 2 tahun) = Rp. 13.020. (dibulatkan menjadi Rp. 13.000)

Berdasarkan perhitungan ini maka setiap tarif tindakan praktik dokter gigi, bisa ditambahkan Rp. 13.000 untuk beban renovasi ventilasi udara yang dibutuhkan agar pasien tidak tertular atau menulari (pasien juga perlu menanggung risiko untuk pengendalian kontrol infeksi yang dilakukan)

\section{B. Variable Cost}

Biaya yang totalnya berubah secara proporsional dengan perubahan output pemakaian. Sebagai contoh, harga baju hazmat adalah Rp. 75.000 dan merupakan bahan yang sekali pakai dibuang, maka pasien akan menanggung langsung Rp. 75.000 tersebut. Berbeda apabila bahan yang dapat dipergunakan beberapa kali, misalkan masker bedah. 1 (satu) boks masker bedah berisi 50 dan saat ini rerata harganya adalah Rp. 250.000 Maka harga satuan/unit cost masker bedah adalah:

Rp. $250.000 / 50=$ Rp. 5.000 
Tabel 9. Contoh rincian harga perlengkapan proteksi untuk praktik dokter gigi dan perawat gigi.

\begin{tabular}{|c|c|c|c|c|c|c|}
\hline NO & NAMA PERLENGKAPAN & $\begin{array}{l}\text { JUMLAH } \\
\text { BARANG }\end{array}$ & HARGA & $\begin{array}{l}\text { HARGA } \\
\text { SATUAN }\end{array}$ & $\begin{array}{l}\text { RANGE HARGA } \\
\text { PASARAN }\end{array}$ & KETERANGAN \\
\hline 1 & $\begin{array}{l}\text { BAJU APD LENGKAP DENGAN } \\
\text { PENUTUP KAKI }\end{array}$ & $1 \mathrm{PCS}$ & 180.000 & 180.000 & $\begin{array}{c}150.000 \mathrm{~s} / \mathrm{d} \\
200.000 \text { per pcs }\end{array}$ & Opsional \\
\hline 2 & $\begin{array}{l}\text { BAJU APD TANPA PENUTUP } \\
\text { KAKI }\end{array}$ & 1 PCS & 110.000 & 110.000 & $\begin{array}{c}50.000 \mathrm{~s} / \mathrm{d} \\
125.000 \text { per pcs }\end{array}$ & \\
\hline 3 & MASKER N95 & 1 PCS & 120.000 & 120.000 & $\begin{array}{c}90.000 \mathrm{~s} / \mathrm{d} \\
125.000 \text { per pcs }\end{array}$ & \\
\hline 4 & MASKER KN95 & 1 PCS & 60.000 & 60.000 & $\begin{array}{c}50.000 \mathrm{~s} / \mathrm{d} 75.000 \\
\text { per pcs }\end{array}$ & Opsional \\
\hline 5 & DISPOSIBLE SURGICAL GOWN & $\begin{array}{c}1 \text { PACK } \\
\text { (10 PCS) }\end{array}$ & 250.000 & 25.000 & $\begin{array}{l}20.000 \mathrm{~s} / \mathrm{d} 25.000 \\
\text { per pack }\end{array}$ & \\
\hline 6 & SEPATU BOOT & 1 PCS & 100.000 & 100.000 & $\begin{array}{c}86.000 \mathrm{~s} / \mathrm{d} \\
150.000 \text { per pcs }\end{array}$ & \\
\hline 7 & DISPOSABLE SHOES COVER & $\begin{array}{c}1 \mathrm{BOX} \\
\text { (50 PCS) }\end{array}$ & 120.000 & 2.400 & $\begin{array}{c}100.000 \mathrm{~s} / \mathrm{d} \\
150.000 \text { per pack }\end{array}$ & Opsional \\
\hline 8 & HELM PROTEKSI & 1 PCS & 180.000 & 180.000 & $\begin{array}{c}150.000 \mathrm{~s} / \mathrm{d} \\
180.000 \text { per pcs }\end{array}$ & \\
\hline 9 & FACE SHILED & 1 PCS & 50.000 & 50.000 & $\begin{array}{c}35.000 \mathrm{~s} / \mathrm{d} 85.000 \\
\text { per pcs }\end{array}$ & Opsional \\
\hline 10 & KACAMATA GOGGLES SAFETY & 1 PCS & 50.000 & 50.000 & $\begin{array}{c}35.000 \mathrm{~s} / \mathrm{d} 75.000 \\
\text { per pcs }\end{array}$ & \\
\hline 11 & $\begin{array}{l}\text { KACAMATA PELINDUNG } \\
\text { DOKTER }\end{array}$ & 1 PCS & 100.000 & 100.000 & $\begin{array}{c}50.000 \mathrm{~s} / \mathrm{d} \\
150.000 \text { per pcs }\end{array}$ & \\
\hline 12 & GLOVES & $\begin{array}{c}1 \mathrm{BOX} \\
\text { (50 PCS) }\end{array}$ & 80.000 & 1.600 & $\begin{array}{c}65.000 \text { s/d } 90.000 \\
\text { per box }\end{array}$ & \\
\hline 13 & DISPOSABLE HAIR CAP & $\begin{array}{c}1 \mathrm{BOX} \\
\text { (50 PCS) }\end{array}$ & 50.000 & 1.000 & $\begin{array}{l}50.000 \mathrm{~s} / \mathrm{d} 75.000 \\
\text { per box }\end{array}$ & \\
\hline 14 & MASKER & $\begin{array}{c}1 \mathrm{BOX} \\
\text { (50 PCS) }\end{array}$ & 300.000 & 6.000 & $\begin{array}{c}225.000 \mathrm{~s} / \mathrm{d} \\
400.000 \text { per box }\end{array}$ & \\
\hline 15 & MICROPORE size 1 & 1 PCS & 17.000 & 17.000 & $\begin{array}{c}15.000 \mathrm{~s} / \mathrm{d} 25.000 \\
\text { per pcs }\end{array}$ & Opsional \\
\hline
\end{tabular}

*HARGA BERBEDA DI TIAP WILAYAH

Perhitungan dibawah ini adalah contoh ilustrasi perhitungan variable cost dan masingmasing dokter gigi diharapkan dapat menghitung masing-masing pengeluaran sesuai dengan bahan yang digunakan. Hal ini dikarenakan variable cost adalah biaya langsung yang timbul dari produksi (kebutuhan bahan saat praktik dokter gigi). Ilustrasi contoh perhitungan variable cost APD dapat dipresentasikan sepert tabel berikut:

Tabel 10. Contoh ilustrasi perhitungan variable cost.

\begin{tabular}{|c|c|c|c|c|}
\hline NO & NAMA PERLENGKAPAN & $\begin{array}{c}\text { JUMLAH SATUAN } \\
\text { PENGGUNAAN }\end{array}$ & ASUMSI HARGA & $\begin{array}{c}\text { HARGA } \\
\text { SATUAN }\end{array}$ \\
\hline 1 & BAJU APD TANPA PENUTUP KAKI & 1 & 75.000 & 75.000 \\
\hline 2 & MASKER KN95 & 4 & 65.000 & 16.250 \\
\hline 3 & DISPOSIBLE SURGICAL GOWN & 1 & 20.000 & 20.000 \\
\hline 4 & SEPATU BOOT & 500 & 300.000 & 600 \\
\hline 5 & KACAMATA PROTEKSI DOKTER & 100 & 50.000 & 500 \\
\hline 6 & GLOVES & 100 & 65.000 & 650 \\
\hline 7 & DISPOSABLE HAIR CAP & 50 & 50.000 & 1.000 \\
\hline 8 & MASKER & 50 & 250.000 & 5.000 \\
\hline & TARIF VARIABLE COST & & 119.000 \\
\hline
\end{tabular}


Dari tabel 10 diatas, jumlah penggunaan adalah asumsi yang ditetapkan berdasarkan pengalaman dokter gigi dan asumsi tersebut disesuaikan dengan pengelolaan penggunaan. Seperti pada item kaca mata proteksi (goggle) yang diasumsikan bisa dipergunakan untuk praktik dokter gigi pada 100 pasien. Tentu saja asumsi tersebut seolah-olah sudah bahwa dokter gigi mempunyai beberapa buah kaca mata proteksi yang dipergunakan secara bergantian dan disinfeksi sesuai rekomendasi. Namun perhitungan asumsi unit cost tetap dianggap bahwa 1 item kaca mata proteksi tersebut dapat bekerja untuk asumsi 100 pasien.

Dari total perhitungan variable cost diatas, maka didapat total harga Rp. 119.000 (dibulatkan menjadi Rp.120.000). Hal ini dapat di asumsikan bahwa setiap tarif tindakan dokter gigi bisa ditambahkan beban variable cost sesuai total perhitungan tersebut.

Apabila kita akan menjumlahkan semua total kebutuhan yang harus dibebankan kepada pasien untuk beban penyesuaian harga di era new normal adalah:

Harga tarif drg (harga lama yang biasa digunakan sebelum era new normal)

+ Fixed Cost + variable cost

$=$ harga tarif lama + Rp. $13.000+$ Rp. 120.000

$=$ harga tarif lama $=$ Rp. 133.000

Perlu diingat pembahasan diatas "total get harus lebih besar dari pada total give" sehingga dengan kenaikan harga sebesar Rp. 133.000 tersebut, maka seorang dokter gigi wajib mempersepsikan pembiayaan tersebut memang dibutuhkan dan dirasakan oleh pasien tersebut.

\section{SUMMARY BOX}

Hal yang perlu diperhatikan dalam perhitungan pembiayaan APD adalah memahami sifat-sifat dari kelompok pembiayaan (fixed cost dan variable cost). Dokter gigi wajib mengelompokkan aktivitas berdasarkan pada sifat kelompok pembiayaan tersebut. 


\section{BAB IX \\ TINDAKAN MITIGASI}

Infeksi virus SARS-CoV-2 sangat mudah menular, baik melalui kontak dengan pasien COVID-19 maupun melalui aerosol yang terbentuk. Jika ditemukan pasien yang diduga kuat terinfeksi SARS-CoV-2, dokter gigi sebaiknya melakukan tindakan mitigasi untuk mencegah penularan lebih lanjut. Tindakan mitigasi ini disesuaikan dengan pustaka dari Djalante dkk (2020). Skrining di awal kedatangan pasien berupa pengukuran suhu tubuh dan pengisian lembar risiko COVID-19 di tempat praktik, dapat membantu dokter gigi dalam menentukan pasien yang boleh masuk ke dalam ruang tunggu. Tetapi jika pasien tidak menunjukkan gejala peningkatan suhu tubuh (orang tanpa gejala/OTG) maka tindakan mitigasi yang dimaksud sebagai berikut:

1) Hentikan tindakan kedokteran gigi lebih lanjut pada pasien suspek COVID-19 untuk kasus non emergensi. Pada kasus emergensi, dokter gigi dapat melakukan penatalaksanaan terapi kedokteran gigi sesuai dengan ketentuan yang sudah dijelaskan sebelumnya.

2) Edukasi pasien suspek COVID-19

a) agar melakukan pemeriksaan COVID-19 di puskesmas atau rumah sakit menggunakan swab PCR dan pemeriksaan radiogram thorax.

b) melakukan pelaporan ke dokter gigi jika sudah diketahui hasil pemeriksaan dari puskesmas atau rumah sakit.

c) agar menjaga jarak dengan anggota keluarga dan orang lain hingga dipastikan sembuh atau bebas infeksi SARS-CoV-2.

d) tidak menggunakan alat makan atau alat lain secara bersama dengan orang lain.

e) melakukan kebiasaan hidup sehat (lihat bab 7).

3) Pada pasien yang telah positif COVID-19 (baik dari hasil rapid test reaktif atau swab PCR positif), lakukan pelaporan ke Dinas Kesehatan Kota/Kabupaten/Desa agar dapat ditindaklanjuti oleh pemerintah. Pelaporan ini dilakukan maksimal dalam waktu $1 \times 24$ jam.

4) Lakukan pendataan pasien siapa saja yang telah menunggu bersama dengan pasien suspek COVID-19 di ruang tunggu. (contoh form. terlampir pada tabel 11).

5) Lakukan monitoring pada pasien suspek COVID-19 melalui aplikasi komunikasi, hingga pasien dinyatakan negatif atau positif COVID-19. Jika pasien dinyatakan negatif, maka formulir yang telah diisi, dapat diabaikan. Jika pasien dinyatakan 
positif, maka laporkan formulir ini ke Dinas Kesehatan Kota/Kabupaten/Desa agar dapat ditindaklanjuti oleh pemerintah dalam waktu 1x24 jam. MOHON AGAR PARA DOKTER GIGI YANG MELAKUKAN PRAKTIK DOKTER GIGI, MENYIMPAN NOMOR CALL CENTRE DINAS KESEHATAN KOTA/KABUPATEN MASING-MASING.

6) Jika dokter gigi mulai menunjukkan gejala COVID-19, sebaiknya tidak melakukan praktik dokter gigi dahulu hingga dinyatakan sembuh.

Tabel 11. Formulir pendataan kontak pasien COVID-19 menurut Kemenkes 27 Maret 2020.

FORMULIR PENDATAAN KONTAK (CONTACT LISTING)

\begin{tabular}{|c|c|c|c|c|c|c|c|c|c|c|c|c|c|c|}
\hline $\begin{array}{c}\text { Nomer Indek } \\
\text { Kasus } \\
\text { Konfirmasi/ } \\
\text { primer' }^{1}\end{array}$ & $\begin{array}{c}\text { Nomer } \\
\text { identifikasi } \\
\text { kontak }^{2}\end{array}$ & $\begin{array}{c}\text { Nama } \\
\text { Lengkap }\end{array}$ & $\begin{array}{c}\text { Jenis } \\
\text { Kelamin } \\
\text { (L/P) }\end{array}$ & Usia & No.HP & Jalan & Desa & amat Lengka & Kabupaten & $\begin{array}{l}\text { Kategori } \\
\text { kontak }^{3}\end{array}$ & $\begin{array}{l}\text { Tanggal } \\
\text { kontak } \\
\text { paparan }\end{array}$ & $\begin{array}{l}\text { Hubungan } \\
\text { dengan } \\
\text { kasus }\end{array}$ & $\begin{array}{c}\text { APD } \\
\text { yang } \\
\text { dipakait }^{4}\end{array}$ & Durasi $i^{5}$ \\
\hline \multirow[t]{2}{*}{$\begin{array}{l}\text { INOCOVID } \\
\# 1\end{array}$} & K1 & & & & & & & & & & & & & \\
\hline & $\mathrm{K} 2$ & & & & & & & & & & & & & \\
\hline & & & & & & & & & & & & & & \\
\hline & & & & & & & & & & & & & & \\
\hline & & & & & & & & & & & & & & \\
\hline & & & & & & & & & & & & & & \\
\hline & & & & & & & & & & & & & & \\
\hline & & & & & & & & & & & & & & \\
\hline
\end{tabular}

Keterangan:

${ }^{1}$ Nomer indeks kasus konfirmasi misal INOCOVID\#1

${ }^{2}$ Nomer identifikasi kontak misalnya K1 merujuk pada kontak nomer 1

${ }^{3}$ Kategori kontak: kontak rumah tangga, rumah sakit, puskesmas, klinik, rekan kerja, sosial (di restoran misalnya), sekolah, satu kendaraan

${ }^{4}$ Jika menggunakan APD terutama kategori kontak fasilitas layanan kesehatan (rumah sakit, IGD, puskesmas, klinik): masker bedah, sarung

tangan, masker N95, dll

${ }^{5}$ Perkiraan lama kontak misalnya 5 menit, 1 jam dsb.

Tambahan informasi: Nomer indeks kasus konfirmasi adalah nomer pasien terkonfirmasi positif COVID-19 melalui rapid test atau swab PCR test (INOCOVID). K1 atau K2 dan seterusnya adalah kode orang dengan riwayat berkontak dengan pasien positif tersebut (INOCOVID). APD apa yang dipakai oleh K1 atau K2 dan seterusnya saat berkontak dengan INOCOVID. 


\section{DAFTAR PUSTAKA}

1. Advice on the use of point-of-care immunodiagnostic tests for COVID-19. Available at: https://www.who.int/news-room/commentaries/detail/advice-on-the-use-of-point-of-careimmunodiagnostic-tests-for-covid-19.

2. Amanat, F. et al. (2020) 'A serological assay to detect SARS-CoV-2 seroconversion in humans', Nature Medicine. Nature Publishing Group, pp. 1-4. doi: 10.1038/s41591-020-0913-5.

3. Asadi, S. et al. (2019) 'Aerosol emission and superemission during human speech increase with voice loudness', Scientific Reports. Nature Publishing Group, 9(1), p. 2348. doi: 10.1038/s41598019-38808-z.

4. Best Practices For Infection Control In Dental Clinics During The Covid-19 Pandemic' Available at: https://cdn.ymaws.com/www.osap.org/resource/resmgr/dentaquest/INC-1353_Best_Practices for_.pdf.

5. CDC. Guidance for Dental Settings, Interim Infection Prevention and Control Guidance for Dental Settings During the COVID-19 Response, 2020. https://www.cdc.gov/coronavirus/2019ncov/hcp/ dental-settings.html

6. CDC. Guidelines for environmental infection control in health-care facilities. Morbidity and Mortality Weekly Report, 2003, 52 (RR-10).

7. CDC. Guidelines for preventing the transmission of Mycobacterium tuberculosis in healthcare settings. Morbidity and Mortality Weekly Report, 2005, 54 (RR-17).

8. CDC Weekly, C. and The Novel Coronavirus Pneumonia Emergency Response Epidemiology Team (2020) 'The Epidemiological Characteristics of an Outbreak of 2019 Novel Coronavirus Diseases (COVID-19) - China, 2020', China CDC Weekly, 2(8), pp. 113-122. doi: 10.46234/ccdcw2020.032.

9. Chen, Y., Liu, Q. and Guo, D. (2020) 'Emerging coronaviruses: Genome structure, replication, and pathogenesis', Journal of Medical Virology, 92(4), pp. 418-423. doi: 10.1002/jmv.25681.

10. Cheryl Yi-Pin Lee et al. (2020) Frontiers / Serological Approaches for COVID-19: Epidemiologic Perspective on Surveillance and Control / Immunology. Available at: https://www.frontiersin.org/ articles/10.3389/fimmu.2020.00879/full.

11. Cochran MA, Miller $\mathrm{CH}$, Sheldrake MS. The efficacy of the rubber dam as a barrier to the spread of microorganisms during dental treatment. J Am Dent Assoc 1989;119:141--4.

12. Communicable Diseases Network (CDNA) Australia, COVID-19 Personal Protective Equipment (PPE) Matrix and Infection Control Recommendations, Ver. 2.0, 04 May 2020.

13. Dai T, Vrahas MS, Murray CK, Hamblin MR. Ultraviolet $C$ irradiation: an alternative antimicrobial approach to localized infections? Expert Rev Anti Infect Ther. 2012 Feb; 10(2): 185-195. doi: 10.1586/eri.11.166

14. Darnell dkk, 2004. Inactivation of the coronavirus that induces severe acute respiratory syndrome, Sars-Cov. J Virol Methods 2004 Oct;121(1):85-91

15. Dayakar, M. M., Shipilova, A. and Gupta, D. (2016) 'Periodontal pocket as a potential reservoir of high risk human papilloma virus: A pilot study', Journal of Indian Society of Periodontology, 20(2), pp. 136-140. doi: 10.4103/0972-124X.170815

16. Djalante R, Lassa J, Setiamarga D, Sudjatma A, Indrawan M, Haryanto B, Mahfud C, Sinapoy MS, Djalante S, Rafliana I, Gunawan LA, Surtiari GAK, Warsilahp H. Review and analysis of current responses to COVID-19 in Indonesia: Period of January to March 2020 2 . Progress in Disaster Science. 2020 Apr; 6: 100091. Published online 2020 Apr 4. doi: 10.1016/j.pdisas.2020.100091. PMCID: PMC7149002

17. Escombe AR dkk. Natural ventilation for the prevention of airborne contagion. PloS Medicine, 2007, 4:309-317. 
18. Fu L, Wang B, Yuan T, Chen X, Ao Y, Fitzpatrick T, Li P, Zhou Y, Lin YF, Duan Q, Luo G, Fan S, Lu Y, Feng A, Zhan Y, Liang B, Cai W, Zhang L, Du X, Linghua Li, Yuelong Shu, Huachun Zou. Clinical characteristics of coronavirus disease 2019 (COVID-19) in China: A systematic review and meta-analysis. J Infect. 2020 Jun; 80(6): 656-665. Published online 2020 Apr 10. doi: 10.1016/j.jinf.2020.03.041

19. Gao Z, Xu Y, Sun C, Wang X, Guo Y, Qiu S, Ma K. A systematic review of asymptomatic infections with COVID-19. J Microbiol Immunol Infect. 2020 May 15 doi: 10.1016/j.jmii.2020.05.001

20. Giovanetti, M. et al. (2020) 'The first two cases of 2019-nCoV in Italy: Where they come from?', Journal of Medical Virology, 92(5), pp. 518-521. doi: 10.1002/jmv.25699.

21. Gottardi W. lodine and iodine compounds. In: Block SS, ed. Disinfection, Sterilization, and Preservation; 4th ed. Philadelphia: Lea \& Febiger. 1991:152-166.

22. Harrel, S. K. and Molinari, J. (2004) 'Aerosols and splatter in dentistry', Journal of the American Dental Association (1939), 135(4), pp. 429-437. doi: 10.14219/jada.archive.2004.0207

23. Herlihey, Gelmi.S, et.al. 2017, The Impact of Environmental Design on Doffing Personal Protective Equipment in a Healthcare Environment: A Formative Human Factors Trial, infection control \& hospital epidemiology, vol. 38, no. 6, page 712-717.

24. https://backpanel.kemlu.go.id/SiteCollectionImages/Lists/News/Allltems/Kampanye\%20Cuci\%20 Tangan-HR.jpg

25. http://hukor.kemkes.go.id/uploads/produk_hukum/PMK\%20No.\%2041\%20ttg\%20Pedoman\%20 Gizi\%20Seimbang.pdf

26. http://promkes.kemkes.go.id/jangan-asal-bersin-dan-batuk-kenali-etika-bersin-dan-batuk-agartidak-menularkan-penyaki

27. http://sehatnegeriku.kemkes.go.id/baca/eat-food-forum/20171026/4423501/sehat-berawalpiring-makanku/

28. https://www.cdc.gov/coronavirus/2019-ncov/hcp/dental-settings.html\#Equipment Considerations

29. https://www.cdc.gov/coronavirus/2019-ncov/hcp/guidance-hcf.html

30. https://www.kemkes.go.id/resources/download/info-terkini/COVID-19\%20dokumen\%20resmi/ REV-04_Pedoman_P2_COVID-19_\%2027\%20Maret2020_Tanpa\%20TTD.pdf.pdf

31. http://www.p2ptm.kemkes.go.id/infographic-p2ptm/hipertensi-penyakit-jantung-danpembuluh-darah/bagaimana-istirahat-yang-cukup

32. https://www.who.int/docs/default-source/coronaviruse/who-ncov-crf.pdf?sfvrsn=84766e69_2

33. https://www.who.int/emergencies/diseases/novel-coronavirus-2019/advice-for-public

34. https://www.who.int/news-room/campaigns/connecting-the-world-to-combat-coronavirus/ healthyathome/healthyathome---physical-activity

35. http://yankes.kemkes.go.id/read-ayo-gunakan-etika-ketika-batuk-4931.html

36. Hui, D. S. et al. (2020) 'The continuing 2019-nCoV epidemic threat of novel coronaviruses to global health - The latest 2019 novel coronavirus outbreak in Wuhan, China', International Journal of Infectious Diseases, 91, pp. 264-266. doi: 10.1016/j.ijid.2020.01.009.

37. Info Infeksi Emerging Kementerian Kesehatan RI. Available at: https://covid19.kemkes.go.id.

38. Indonesia Coronavirus: 54,010 Cases and 2,754 Deaths - Worldometer (no date). Available at: https://www.worldometers.info/coronavirus/country/indonesia/ (Accessed: 29 June 2020).

39. Indonesia Population (2020) - Worldometer (2020). Available at: https://www.worldometers.info/ world-population/indonesia-population.

40. Jacofsky, D., Jacofsky, E. M. and Jacofsky, M. (2020) 'Understanding Antibody Testing for COVID19', The Journal of Arthroplasty. (Special COVID-19 Supplement), 35(7, Supplement), pp. S74S81. doi: 10.1016/j.arth.2020.04.055.

41. Kampf, G. et al. (2020) 'Persistence of coronaviruses on inanimate surfaces and their inactivation with biocidal agents', Journal of Hospital Infection, 104(3), pp. 246-251. doi: 10.1016/j. jhin.2020.01.022.K.Tsia, K.Lee and Q.Lai (no date) Oral Diseases, Wiley Online Library. doi: 10.1111/(ISSN)1601-0825. 
42. Keputusan Menkes RI No. HK.01.07/MENKES/328/2020 tentang Panduan Pencegahan dan Pengendalian Corona Virus Disease 2019 (COVID-19) di tempat kerja, perkantoran dan Indutri dalam mendukung keberlangsungan usah pada situasi pandemic.

43. Kirk-Bayley J, ChallacombeS, SunkaraneniVS, Combes J. The use of Povidone lodine nasal spray and mouthwash during the current COVID-19 pandemic may protect healthcare workers and reduce cross infection. (March 28, 2020). Available at SSRN: https://ssrn.com/abstract=3563092.

44. K.Tsia, K.Lee and Q.Lai (no date) Oral Diseases, Wiley Online Library. doi: 10.1111/(ISSN)1601 0825.

45. Lammers MJW, Lea J, Westerberg BD. Guidance for otolaryngology health care workers performing aerosol generating medical procedures during the COVID-19 pandemic. Journal of Otolaryngology - Head and Neck Surgery (2020) 49:36

46. Li, H. et al. (2020) 'Coronavirus disease 2019 (COVID-19): current status and future perspectives', International Journal of Antimicrobial Agents, 55(5), p. 105951. doi: 10.1016/j. ijantimicag.2020.105951.

47. Li, X. et al. (2020) 'Molecular immune pathogenesis and diagnosis of COVID-19', Journal of Pharmaceutical Analysis, 10(2), pp. 102-108. doi: 10.1016/j.jpha.2020.03.001

48. Li, $\mathrm{Y}$ et al. An evaluation of the ventilation performance of new SARS isolation wards in nine hospitals in Hong Kong. Indoor and Built Environment, 2007, 16(5):400-410

49. Liang T. Handbook of COVID-19 Prevention and Treatment. https://video-intl.alicdn.com/ Handbook\%20of\%20COVID-19\%20Prevention\%20and\%20Treatment.pdf

50. Liu, L. et al. (2011) 'Epithelial cells lining salivary gland ducts are early target cells of severe acute respiratory syndrome coronavirus infection in the upper respiratory tracts of rhesus macaques', Journal of Virology, 85(8), pp. 4025-4030. doi: 10.1128/JVI.02292-10.

51. MacLean RR, Valentine GW, Jatlow PI, Sofuoglu M. Inhalation of Alcohol Vapor: Measurement and Implications. Alcohol Clin Exp Res. 2017 Feb; 41(2): 238-250.

52. Micik, R. E. et al. (1969) 'Studies on Dental Aerobiology: I. Bacterial Aerosols Generated during Dental Procedures', Journal of Dental Research. SAGE Publications Inc, 48(1), pp. 49-56. doi: 10.1177/00220345690480012401.

53. Nejatidanesh, F. et al. (2013) 'Risk of Contamination of Different Areas of Dentist's Face During Dental Practices', International Journal of Preventive Medicine, 4(5), pp. 611-615. Available at: https://www.ncbi.nlm.nih.gov/pmc/articles/PMC3733195.

54. Nile, S. H. et al. (2020) 'COVID-19: Pathogenesis, cytokine storm and therapeutic potential of interferons', Cytokine \& Growth Factor Reviews, 53, pp. 66-70. doi: 10.1016/j.cytogfr.2020.05.002.

55. Non-Contact Thermometers for Detecting Fever: A Review of Clinical Effectiveness Rapid Response Report: Summary with Critical Appraisal. Ottawa (ON): Canadian Agency for Drugs and Technologies in Health; 2014 Nov 20.

56. Olsen, S. J. et al. (2003) 'Transmission of the Severe Acute Respiratory Syndrome on Aircraft', New England Journal of Medicine. Massachusetts Medical Society, 349(25), pp. 2416-2422. doi: 10.1056/NEJMoa031349.

57. Paraskevis, D. et al. (2020) 'Full-genome evolutionary analysis of the novel corona virus (2019$\mathrm{nCoV}$ ) rejects the hypothesis of emergence as a result of a recent recombination event', Infection, Genetics and Evolution, 79, p. 104212. doi: 10.1016/j.meegid.2020.104212.

58. 'Pedoman Kesiapsiagaan Menghadapi Novel Corona Virus (COVID-19) » Info Infeksi Emerging Kementerian Kesehatan RI' (no date) Info Infeksi Emerging Kementerian Kesehatan RI. Available at: https://covid19.kemkes.go.id/downloads.

59. Pedoman Pengelolaan Limbah Rumah Sakit Rujukan, Rumah Sakit Darurat Dan Puskesmas yang Menangani Pasien COVID-19, yang dikeluarkan oleh Direktorat Jenderal Kesehatan Masyarakat, Direktorat Kesehatan Lingkungan, Kementerian Kesehatan RI tanggal 14 April 2020.

60. Pedoman untuk Disinfeksi dan Sterilisasi di Fasilitas Layanan Kesehatan (2008) Pembaruan terakhir: Mei 201912 dari 163. 
61. Pedrosa, M. da S., Sipert, C. R. and Nogueira, F. N.'Altered Taste in Patients with COVID-19: The Potential Role of Salivary Glands', Oral Diseases, n/a(n/a). doi: 10.1111/odi.13496

62. Peng $\mathrm{X}, \mathrm{dkk}$. Transmission routes of $2019-\mathrm{nCoV}$ and controlsin dental practice. International Journal of Oral Science (2020) 12:9.

63. Percepatan Penanganan COVID19 Gugus-Tugas (28062020) Infografis COVID-19 (28 Juni 2020) Berita Terkini / Gugus Tugas Percepatan Penanganan COVID-19, covid19.go.id. Available at: https://covid19.go.id/p/berita/infografis-covid-19-28-juni-2020.

64. Ratnesar-Shumate dkk, 2020. Simulated sunlight rapidly inactives SARS-CoV-2 on surfaces. JID 2020;XX:1-9.

65. Reimer K, dkk. Zent.bl Hyg Umweltmed. 1997/98;200:423-434.

66. Rothan, H. A. and Byrareddy, S. N. (2020) 'The epidemiology and pathogenesis of coronavirus disease (COVID-19) outbreak', Journal of Autoimmunity, 109, p. 102433. doi: 10.1016/j.jaut.2020.102433.

67. Rujukan : Guideline for Environmental Infection Control in Health- Care Facilities, CDC 2008 update May 2020.

68. Rujukan: WHO. Infection prevention and control during health care when novel coronavirus (nCoV) infection is suspected. WHO; 2020. Interim guidance. 25 January 2020.

69. Scott Froum and Michelle Strange (2020) COVID-19 and the problem with dental aerosols, PerioImplant Advisory. Available at: https://www.perioimplantadvisory.com/periodontics/oralmedicine-anesthetics-and-oral-systemic-connection/article/14173521/covid19-and-the-problemwith-dental-aerosols.

70. Sethuraman, N., Jeremiah, S. S. and Ryo, A. (2020) 'Interpreting Diagnostic Tests for SARS-CoV-2', JAMA. American Medical Association, 323(22), pp. 2249-2251. doi: 10.1001/jama.2020.8259.

71. Shereen, M. A. et al. (2020) 'COVID-19 infection: Origin, transmission, and characteristics of human coronaviruses', Journal of Advanced Research, 24, pp. 91-98. doi: 10.1016/j.jare.2020.03.005.

72. Tang JW dkk. Factors involved in the aerosol transmission of infection and control of ventilation in healthcare premises. Journal of Hospital Infection, 2006, 64(2):100-114.

73. To, K. K.-W., Tsang, O. T.-Y., Chik-Yan Yip, C., et al. (2020) 'Consistent detection of 2019 novel coronavirus in saliva', Clinical Infectious Diseases: An Official Publication of the Infectious Diseases Society of America. doi: 10.1093/cid/ciaa149.

74. To, K. K.-W., Tsang, O. T.-Y., Leung, W.-S., et al. (2020) 'Temporal profiles of viral load in posterior oropharyngeal saliva samples and serum antibody responses during infection by SARS-CoV-2: an observational cohort study', The Lancet Infectious Diseases. Elsevier, 20(5), pp. 565-574. doi: 10.1016/S1473-3099(20)30196-1.

75. Van Doremalen, N. et al. (2020) 'Aerosol and Surface Stability of SARS-CoV-2 as Compared with SARS-CoV-1', New England Journal of Medicine. Massachusetts Medical Society, 382(16), pp. 1564-1567. doi: 10.1056/NEJMc2004973.

76. Walton RE, Torabinejad M. 2002. Principles and practice of endodontics. 3rd Ed. Saunders.

77. Wang, J. and Du, G. (2020) 'COVID-19 may transmit through aerosol', Irish Journal of Medical Science (1971 -). doi: 10.1007/s11845-020-02218-2.

78. WHO. Infection prevention and control of epidemic- and pandemic-prone acute respiratory diseases in health care - WHO interim guidelines. Geneva, World Health Organization, 2007.

79. WHO. Natural Ventilation for Infection Control in Health-Care Settings - WHO interim guidelines. Geneva, World Health Organization, 2009.

80. World Health Organization, Pandemic and Epidemic Diseases and World Health Organization (2014) Infection prevention and control of epidemic- and pandemic-prone acute respiratory infections in health care: WHO guidelines. Available at: http://apps.who.int/iris/bitstre am/10665/112656/1/9789241507134_eng.pdf?ua=1 (Accessed: 29 June 2020).

81. Xu, H. et al. (2020) 'High expression of ACE2 receptor of 2019-nCoV on the epithelial cells of oral mucosa', International Journal of Oral Science. Nature Publishing Group, 12(1), pp. 1-5. doi: 10.1038/s41368-020-0074-x. 
82. Yin R, Dai T, Avci P, Jorge AES, de Melo WCMA, Vecchio D, Huang YY, Gupta A, Hamblin MR. Light based anti-infectives: ultraviolet $C$ irradiation, photodynamic therapy, blue light, and beyond. Curr Opin Pharmacol. 2013 Oct; 13(5): 10.1016/j.coph.2013.08.009.

83. Zhou, P. et al. (2020) 'A pneumonia outbreak associated with a new coronavirus of probable bat origin', Nature. Nature Publishing Group, 579(7798), pp. 270-273. doi: 10.1038/s41586-0202012-7. 


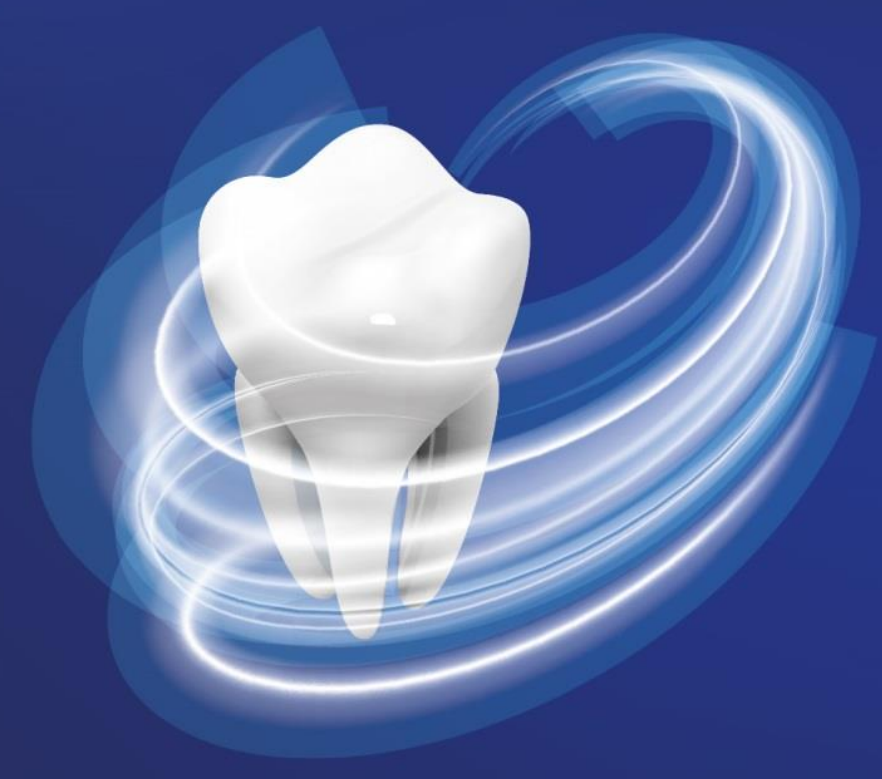

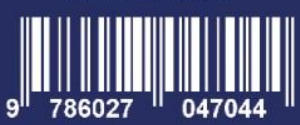

